\title{
THE LABOR MOVEMENT AND THE FARMER
}

\section{HAYES ROBBINS}



To my goov finke Espanfillich

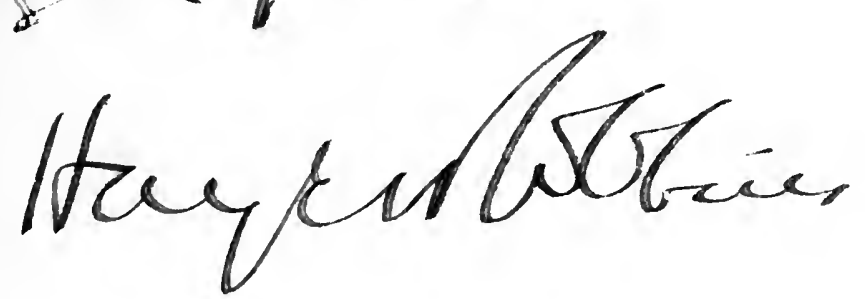

Kor

1422 


\section{Digitized by the Internet Archive in 2007 with funding from Microsoft Corporation}


THE FARMER'S BOOKSHELF

Edited by

KENYON L. BUTTERFIELD 



\section{THE LABOR MOVEMENT AND THE FARMER}

BY

HAYES ROBBINS

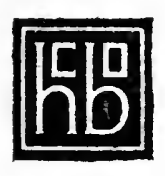

NEW YORK

HARCOURT, BRACE AND COMPANY 


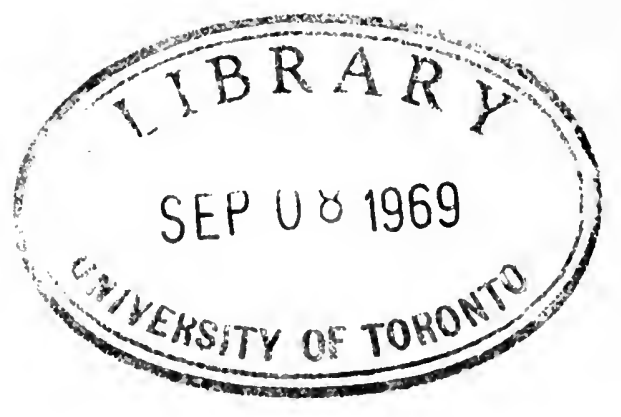

COPYRIGHT, 1922, BY

HARCOURT, BRACE AND COMPANY, INC.

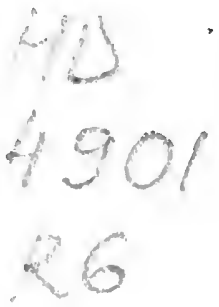

PRINTED IN THE U. S. A. BY THE QUINN \& BODEN COMPANY RAHWAY. N. J 


\section{EDITOR'S PREFACE}

THE main object of a great farmers' organization is doubtless to represent the interests of the farmers. But it has, or should have, another purpose almost equally important, to serve as a medium of education of the farmers concerning all questions of national import.

One of these questions of first-class importance is the labor question. No matter what one's views may be about the policies or possibilities of organized labor, the labor movement itself is as inevitable as the seedtime and harvest with the farmer. It cannot be ignored. Therefore, it should be understood.

I am inclined to think that the farmers have tended toward either a general opposition to the labor union idea or to feel that it is not much of their affair. But the very success of farmers' organizations in the last few years brings the farmers face to face with the labor question as well as other problems of like importance. Now no question can be faced fairly unless its main outlines are clearly understood. It has seemed, therefore, that a real contribution might be made if we could have a book in this Farmer's Bookshelf that would describe sympathetically but dispassionately and accurately, just what this labor movement is. It is believed that this book will meet the need. It is written in simple, direct style and, best of all, it aims to tell 
the truth, to show how and why workingmen have organized for the last hundred years, why they do the things they do, how the remedies they have tried actually work in practice, and what the much-used phrase "industrial democracy" really means. There is a concise statement of the various branches of the movement here and in Europe, who its leaders are, and the latest programs of trade unionism, socialism, the I. W. W., and communism. The big central question of all is gone into in plain terms, and in the light of facts, whether a rising standard of living for labor is really to the cost and injury of the rest of the public or a necessary part of the general prosperity and progress.

The author, Mr. Hayes Robbins, has for many years been in close touch with the labor movement and he has written freely and acceptably in this field. He has had the confidence of both employers and labor organizations as is evidenced by his direction of the Civic Federation of New England, which was devoted to the betterment of relations between employers and employees and which had a membership including the heads of most of the leading New England industries and practically every labor organization of consequence.

This book should be a valuable and practical help for the Grange lecture hour, for community study clubs, for debates and for supplementary reading in agricultural high schools, as well as for individual reading and study.

Kenyon L. Butterfield. 


\section{CONTENTS}

CHAPTER
PAGH

I How THe Labor Question Comes to THE FARM •: 3

II If THE FARMer WORKED fOR WAGES • . • • 7

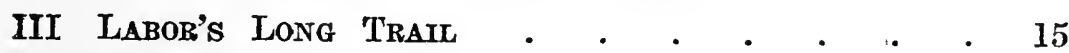

IV Amerioan Trade Unionism . . . . . . . . 31

V Radical Movements in the United States . . 53

VI European Labor Movements To-daY • • . . $\quad 66$

VII INTERNATIONAL LABOR RELATIONS • • • • • $\quad$ • 88

VIII What Does Labor Want? . . . . . . . 97

IX The Public Sitting in Judgment . . . . . 113

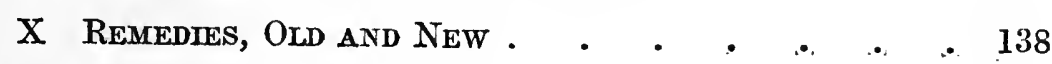

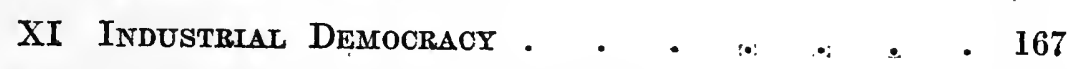

XII What Shall We Do About It? • • • . . 178 


\section{THE LABOR MOVEMENT AND THE FARMER}





\section{I}

HOW THE LABOR QUESTION COMES TO THE FARM

Every farmer who engages a carpenter or painter, or visits the blacksmith, or pays monthly wages to farm help, meets the labor question face to face. It comes up to him in a hundred other ways, some readily seen, others not so clear. In everything he buys-his clothing, groceries, tools, stock feed-the labor cost is the main item in the making of the price. Whenever he pays the freight bill on a shipment of his products to market he thinks of the wages of railroad men.

It meets him at another turn. Young men, raised in the country, do not stay to work the farms. Good help is hard to get; the farmer must compete for it, against the higher wages and shorter working day of the cities and mill towns. In other words, the labor conditions of the outside world come immediately back to the farm in dollars and cents, but not in higher costs only. The immense wage rolls paid every week in the cities and mill towns are in great part the farmer's market. He does not need to be told what this means. When the market is far distant, help may be plentiful and the young men may stay on the farms, because it is difficult to get away, but the labor advantage disappears in the long freight haul, commissions and selling expenses. The same industrial centers 
that make the farmer's help question harder, as they come nearer to him, mean also a vast population close at home that buys farm products and does not raise them.

The hiring and keeping of farm help is a problem upon which the farmer himself can give more information than the books afford. Industrial labor is another matter. The farm scatters labor, the factory draws it together, and gives us a problem of its own with a history of its own. In that history the reasons appear for the great organized movements which have grown up in every modern country, and the reasons also, which do not commonly show on the surface, for most of the bitterly disputed issues and practices in present-day relations between workingmen and employers.

We are accustomed to think of the whole matter quite too much as a thing apart. Merely in naming it the "labor problem" we set it off as something far removed from every-day life, a matter of endless complicated disputes, lockouts and. strikes, to be settled by courts or police. That is one of the outer sides of the labor problem: another outer side is a commonplace world of industry at peace which seldom gets a newspaper headline. But the inside of the labor problem any man may find in himself. In his own necessities and motives, in his ambition for something more or better than that he already has, are the roots of all that gives rise to a labor movement or any point to arguments on wages and hours, on trade unions and shop rules, on plans of social reconstruction.

And in the modern world these roots have grown 
and spread into a great industrial Fact. The labor movement is here, and is not to be escaped. It knows what it wants, and why it grows stronger with all opposition, and it has the rest of us at a disadvantage because we do not. What it asks of us first is the easiest of all its demands to grant, but in some ways the most important-a patient attempt to understand it, broadly and fairly, as one would wish one's own special difficulties in the making of a living to be understood. 'And it is a request that no man with anything at stake in the industrial world he lives in-and who has not?can quite afford to ignore.

It is as possible for citizens of some one occupation to do their own largest interest serious harm by a misjudged attitude towards another industrial group as it is to ruin a field with the wrong fertilizer or an orchard by neglect. Farm and factory are bound inseparably together. Men who work at the bench or loom and men who work on the land are citizens of one community. What each may do in industry or in politics can and does powerfully affect the welfare of the other.

The farmer who has come to see what this means will take the time, as a matter of ordinary business judgment if for no larger reason, to know what this industrial labor movement actually is, how and why it arose, what its aims are for to-day and for to-morrow, the reasons for the things it does, the effects upon all of us of whatever it has accomplished thus far, what, if anything, he has in common with it, and whether he ought to attempt to destroy it as many have attempted 


\section{THE LABOR MOVEMENT AND THE FARMER}

before or to coöperate where he can and oppose where he must.

It is to help towards this end, if possible, that the story is here related of the industrial labor movement as it is, the things it believes in from the wage-earner's own viewpoint, the things it is working for, and what we may expect of it in the years next ahead. 


\section{II}

\section{IF THE FARMER WORKED FOR WAGES}

There are the same differences of opinion on the labor question among farmers as among other citizens-business men, politicians, clergymen, educators. One naturally expects employers to be hostile to trade unions, for instance, but there are in almost every industry important concerns which have accepted the union for many years as the most practical method, as they see it, of dealing with workingmen in large numbers.

\section{WHAT DO FARMERS THINK OF LABOR?}

The leading farm organizations have taken unlike positions on the subject. The Farmer-Labor Party is an attempt to unite wage-earners and farmers in a political movement, of aims apparently too radical to attract at present a large following. A number of farmers' associations, meeting at the call of the National Board of Farm Organizations in April, 1918, adopted a "Win the War Program" in the course of which it was declared "that the interests of all workers are essentially the same, that the apparent differences which separate those who work on farms from those who work in industry are temporary and superficial, and that it is the clear duty of these two greatest divisions of our 
people to work together for the common welfare and general good."

The National Grange, on the other hand, sees very little common ground for the farmer and the labor movement. It declared at its Boston meeting, in 1920, that increased wages and decreased hours of industrial workers "influence farm wages and farm hours in the same way, and still further decrease farm production, and increase farm costs," besides adding to the cost of distribution "which in turn is paid by the consumers." Further: "The National Grange insists that no settlement of industrial controversies can be fairly made without taking into account the effect of such settlement on the greatest of all industries-agriculture." Collective bargaining was favored, but not union-shop contracts on the part of industrial workers.

A critical attitude, not necessarily hostile, is also taken by the American Farm Bureau Federation, the largest and most widely distributed of all the farm organizations. Resolutions adopted at its national conferences in 1919 and 1920 favor "a coöperative attitude toward all movements promoting the welfare of American institutions" and recognize "the right of any and every class of our people to associate themselves for material benefit," but maintain that "a large factor in the high cost of living is the curtailment of production through short hours, lessened efficiency of labor and strikes." The right of every citizen is asserted "to the full and unhampered privilege of disposing of his labor or the products thereof as he may individually desire." 
It is clear of course what the chief objections to the labor movement are, in the minds of the framers of these resolutions. They are the objections oftenest raised in discussions of the subject everywhere. Are they based on a right statement of the facts? Do all labor organizations practise the methods criticized, or do the abuses come mainly of special causes and traits of character found in every human association? Does it follow necessarily that high wages and a limited working day mean high costs and high prices for the farmer and for everybody else?

\section{SEEING THE OTHER MAN's SIDE}

The workingman at any rate is fairly entitled to be heard on these matters. They are as important to him as the difficulties and needs of agriculture are important to the farmer, who often has reason to feel as keenly as does the wage-earner that the rest of the community knows little of his side of the case and takes little trouble to judge it fairly. The idea of better prices for farm products gets as little public sympathy, as a rule, as that of better wages for labor. It is, in fact, a common protest of farm organizations and the farm press that the public does not understand agricultural conditions and is opposed in advance to anything that seems likely to cost it something.

What is most needed, in working out our relations in industry as they must be worked out if democracy is to endure, is a willingness to put one's self in the other man's place. If people who are not farmers, for 
instance, would seriously attempt to see matters from the standpoint of the man who makes his living on the land, with his crop risks, his market uncertainties, his help difficulties, his early and late hours, his taxes, his high interest rates, the struggle to "make both ends meet," it is probable they would get a quite different idea of the needs of agriculture, of why the farmer demands certain constructive measures suited to new conditions. And this is exactly what the wage-earner asks of the farmer, as of the whole community. It does not necessarily mean agreeing with all of his demands or assuming that all of his methods are justified. It does mean a willingness to see what lies back of his efforts, to acknowledge that he is acting, according to his experience and within his limitations, from the same human motives that govern us all.

\section{FARM IIFE AND FACTORY LIFE}

From the standpoint of farm life on its harder side the mill worker with his regular hours and regular pay often seems to have much the better of it. There is another side of the picture to remember, which accounts in part for many things workingmen contend for, and which the farmer in the nature of the case has little opportunity to see at first hand.

The city wage-worker as a rule is a rent-payer. It is true of the great majority that there is no piece of earth and no roof which he calls his own. If he is a man of family his savings are seldom large, and if he loses his job he must "move on." There are no stored crops 
in the cellar, no fuel in the shed, no stock in the barn, to tide over a time of misfortune. Practically his all, for himself and those dependent upon him, is staked on his ability to hold his job. The business conditions that make or abolish his job are beyond his control. While the job lasts all may go well, when it is gone all is gone. If sickness or disability exhaust what savings there may be, and the rent is unpaid, again he must move on-but where?

He does not know the drawbacks and hardships of the farmer's "job," but he sees at any rate that it is the farmer's own, that he has not always before him the possibility of discharge on a moment's notice, or indefinite lay-off. The farmer's ownership of the farm or his equity in it, with his stock and tools, are his capital, his anchor to windward. There are many resources to fall back upon before actual destitution comes. For the wage-laborer, in the ranks of the majority, it may be one step from loss of employment to the bread line. His muscle and skill are for the most part his only capital, and it is not capital that can be stored up for to-morrow if it is not used to-day. Earning time lost is his crop failure, never made up.

Putting yourself in the workingman's place means also to accept the idea of working for another instead of for one's self. To the normally minded farmer, probably, the sense of independence, of working on his own land with his own tools and according to his own ideas, is one of the chief compensations for the hard labor and relatively limited opportunities of farm life. Along with it goes the satisfaction of knowing that improve- 
ments made to his property, as opportunity offers, are additions to its value. The results of his planning and labor are constantly before his eyes. The product of the mill-worker is gone the instant his hand leaves it; it is one of the many parts of a finished article which he never sees and could not possibly identify as his own.

The conditions of life in all too many mill towns, especially of the poorer workmen renting small tenements in crowded streets, are to be borne in mind in judging their state of mind and some of the things they do. For it must be remembered that the great majority of wage-earners are not the highly paid workmen in building trades and other skilled crafts, or the railroad engineers on favorable runs, whose wages are commonly quoted in the newspapers. The farmer in modest circumstances who reads of western "farm barons" riding about in high-powered automobiles knows very well that this is not the custom nor within the power of most men engaged in agriculture. Quite naturally he protests at the wrong impression given of conditions in his industry as a whole. It should not be difficult for him to understand the feeling of the workingman who sees the wage rates in exceptional occupations quoted as evidence that wage-earners generally are overpaid and deserve no public sympathy in efforts to maintain or improve their position.

\section{WHY WAGE-EARNERS AND FARMERS ORGANIZE}

The workingman turns to organization to afford him something of the defense against ill fortune, something 
of the means of bettering his condition, that land and a home afford the farmer. The bulwark which even a small capital might give him he attempts to erect, so far as possible, in the power he finds in common action with fellow workmen to bargain for his labor on something like equal terms. To say that this in itself is a perfectly natural and in many ways a wise course for him to take is not of course to defend the entire program of the labor movement, but the farmer to-day can appreciate as never before why any great industrial group should feel the need of organization. He has come to feel it himself in late years, in a remarkable degree, and he is meeting much the same criticism and objections to his special program that the workingman long since grew accustomed to.

Farmers have sometimes pursued the policy of withholding certain great staples-wheat, cotton, fruit, tobacco-from overstocked markets for a time; they have been indignant at criticisms of this course as an attempt to "corner" necessities of life. They have heard their coöperative buying and selling experiments described as "farmers' trusts," and the effort to legalize collective bargaining for farmers as "class legislation." It is outside our purpose to pass on the merits of these policies. The point is, merely, that it should not be difficult for the farmer to put himself in the place of the workingman who hears his union described as a "labor trust" seeking to "corner" the labor supply. It may actually be that, in some cases, but there still is room for thought of the actual objects he has in mind and the conditions he is obliged to face. 
There is of course no exact parallel between the programs of these two great industrial groups. No doubt there is more in some of the policies of each to justify criticism than in their deeper purposes, but this at least should be plain. The problems farmer and wageworker face in the common necessity of making a living have enough points of likeness that the obligation lies fairly upon each, before passing judgment upon any proposal or aim of the other, to study it with open mind, attempting to see the conditions as the other is obliged. to-and this on the common ground of good citizenship.

It is not a simple matter at best to weigh justly the claims of other men, or the things they do. It is all but impossible without some knowledge of what came before, perhaps in slow accumulation through many years. How, then, did the labor movement grow up, and why? It is no dry record of facts and figures but an intensely. interesting chapter in human progress. 


\section{III}

\section{LABOR'S LONG TRAIL}

There has been a labor question ever since human beings emerged from slavery and began to work for wages. It is not entirely as a flight of fancy that Moses is sometimes named as the first labor leader, the refusal of his people to make bricks without straw as the first labor dispute, and Pharaoh's pursuit as the first attempt of government to prohibit strikes!

There was industrial peace of course when men were bought and sold with the land. Labor advocates are quite within the facts in saying that just as soon as a man gains the right to a voice in what he shall do with his own hand and brain the field is open for argument with any other man who seeks his help, and a labor question is born.

Before the beginnings of primitive manufacture in England, some seven centuries ago, the only labor question was the amount of produce to be paid the lord of the manor for the use of an allotment of land. It was a farm workers' question, and it was decided exclusively by the lord. There was no issue of wages, much less of hours: the right to organize did not exist. All land workers except free tenants were in some manner bound to the soil. 
FARMERS THE FIRST WAGE-EARNERS

The first wage-earners in Anglo-Saxon civilization, forming a distinct class, were farm workers-the cottars, of medieval England. Allotted too little land to provide a living, they hired themselves out for wages to help cultivate the lands of nobles and prosperous free tenants. And the first labor problem worthy the name arose on a question of wages of these "farmers." The scarcity of help after the Great Plague, in 1348, led to a sudden and astonishing rise of wages-not less than fifty per cent. So unheard of a thing was more disturbing to the simple industrial life of the time than the remarkable wage advances following the world war have been to ours.

\section{A FARM-WORKERS' STRIKE}

The first labor unions, but in no modern sense, were combinations of farm workers and tenants in this same period following the Plague. They were mob attempts to resist the nobles in their effort to hold them to the land or to the payment of their ancient dues in produce. And the first "nation-wide strike" was entirely a farmworkers' uprising, the Peasants' Revolt of 1381, under the lead of Wat Tyler.

There is an oddly familiar sound in the preachings of some of the forerunners of this outbreak- "agitators" like Wiklif and Ball. The wrongs and hardships they denounced were those of farmers rather than of industrial workers. "Good people," said John Ball, "things 
will never be well in England so long as there be villeins and gentlemen. By what right are they whom we call lords greater than we? On what grounds have they deserved it? Why do they hold us in serfage? They have leisure and fine houses: we have pain and labor, and the wind and rain in the fields. And yet it is of us and our toil that these men hold their estate."

The Peasants' Revolt was a more violent affair than the most riotous of labor strikes in our day. There was great disorder and loss of life. It was put down with an iron hand, but the ideas which underlay it had taken deep root and could not be stamped out. Within fifty years, villeinage and serfage in the old sense practically had disappeared from English life. It was a desperate and wasteful struggle, measured in immediate cost, but in the longer view a milestone in the advance of civilization.

\section{LAWS TO SUPPRESS FARM WORKERS}

The first laws to suppress labor demands were chiefly against farm workers. The Statutes of Laborers (1350) provided that whoever asked more than the old rate of wages should be imprisoned; those who ran away from the land to which they were attached were to be branded with hot irons. None of these measures succeeded either in keeping wages down or in preventing laborers from deserting to jobs where the new wage rates were paid.

More than two hundred years later, in the time of Queen Elizabeth, a very different plan of controlling labor by law was put into effect. Wage rates were fixed 
at regular intervals by justices of the peace, in quarter sessions. Both employers and employees were bound to abide by them. Possibly the germ idea of proposals in our own time for compulsory arbitration and industrial courts is to be found in this famous statute of 1563. Its professed object was to guarantee laborers at least a living wage, at a time of widespread distress; the actual effect was to put the control of wages into the hands of the landed proprietors and employers. It has been described as "a conspiracy concocted by the law and carried out by the parties interested in its success." 1 At the same time a "conspiracy" of workingmen to improve their condition by uniting or agreeing "not to do their work but at a certain price" was prohibited, under penalty of the pillory and loss of an ear.

This time legal regulation proved more effective. Thousands of acres of land were being enclosed for sheep raising, and great numbers of farm laborers were searching the country for work. In the towns the old guilds were decaying. Both farm workers and artisans were forbidden to organize in self-defense. Wages, measured in purchasing power, declined upon the whole for a century and a half. Pauperism steadily increased, and the attempts to relieve it by poor laws led to still other abuses. It was a common practice, for instance, for employers in one parish or another, through the quarter-sessions courts, to reduce wages to such a point that it was necessary to grant to laborers more poor relief than the parish could afford to pay. The deficit, under

${ }^{1}$ Six Centuries of Work and Wages (Rogers), p. 398. 
the law, could then be assessed on neighboring parishes. Here again, farm workers chiefly were the sufferers.

\section{CRAFTSMEN AND GUILDS}

It is a curious thing that although the first workingmen to create a "labor problem" were peasants-farmers-the first workingmen in manufactures were not -wage-earners at all. They were independent craftsmen, working in their homes, buying their own materials and selling their own products, very much as the farmer tills his own land and sells his own crops to-day. Each group, going back to the industrial life of old England, has occupied very nearly the position of the other.

Still, the old craft guilds had some points of likeness to the trade union of to-day. It is true, the early weavers and carpenters and shoemakers did not work for employers. They dealt with their own customers, but in their guilds were the roots of several ideas common to modern labor organization, as well as some others which might well play a larger part than they ordinarily do to-day. For instance, it is said of the fifteenth century guilds, when every trade pursued by as many as twenty men had a guild of its own, that they "attempted to suppress the production of wares by irresponsible persons who were not members of the craft." Bad work was punished, and night work prohibited because it led to poor work. A member was supposed to work not only for his own advantage "but for the reputation and good of his trade-'for the honour of the good folks of such misteries.' . . . The guild 
also took care to secure a supply of competent workmen for the future (and at the same time to restrain competition) by training a limited number of young people in its particular industry. . . The guild, moreover, exercised some kind of moral control over its members, and secured their good behavior, thus forming an effective branch of the social police. On the other hand, it had many of the characteristics of a benevolent society, providing against sickness and death among those belonging to it." 1

Six hundred years ago there was practically no such thing as working in a shop for wages, under an employer. By the time of Queen Elizabeth many an English village had one or more little factories, usually connected with the home of the craftsman operating it. It was still hand work mainly, under this "domestic system," and the master worked alongside his journeyman. Wages were poor and the conditions often far from ideal, but in this close contact between employer and workingman there was very generally a sense of mutual interest and obligation which all but disappeared with the coming of machinery. Only in recent years have there been serious efforts in important industries to restore it.

\section{COMING OF THE FACTORY SYSTEM}

It is almost exactly a century and a half since the first of the great inventions which have made the labor problem as we know it a matter no longer chiefly of farmers and farm laborers but of industrial wage-earners. Five

${ }^{2}$ Industry in England (Gibbins), p. 95. 
years before the American Revolution the Englishman Hargreaves patented in 1770 a spinning jenny which enabled him to spin eight times as much yarn at a time as before. Within the next ten years came the still more efficient spinning frames of Arkwright and Crompton, and in 178 s Cartwright's power loom. In the same year Watt's crude steam engine was first used in a factory.

The old order passed away. Neither the American Revolution nor the French so changed the future of civilization and the relations of men, both in industry and politics, as these little noticed inventions. At first and for many years they reduced the wage-earner to abject helplessness. A gulf opened between him and his employer, who very often now was merely an absentee owner of the business. In his place came the overseer, charged with the task of getting the last ounce of available working power out of the operatives. Women and children could be used now in factories as well as men, and they were so used in great numbers, at wages so pitiful that it soon required the earnings of an entire family, working fourteen to sixteen hours a day, to provide the meanest of food and shelter.

\section{FACTORY SLAVERY}

The picture given us in many accounts and official reports of the time, of the miserable lot of these unprotected laborers of the early factory system, is a terrible one. Manufacturers arranged with the workhouse overseers for supplies of pauper children. They were 
brought to the factory districts, sometimes by regular traffickers who kept them, often in dark cellars, until the mill-owners could examine them and judge of their strength and endurance, "exactly as did the slavedealers in the American markets," says the historian Gibbins: ${ }^{1}$

After that the children were simply at the mercy of their owners, nominally as apprentices, but in reality as mere slaves, who got no wages, and whom it was not worth while even to feed or clothe properly, because they were so cheap, and their places could be so easily supplied. ... Their treatment was most inhuman. The hours of their labor were limited only by exhaustion, after many modes of torture had been unavailingly applied to force continued work. Illness was no excuse: no child was accounted ill till it was positively impossible to force him or her to continue to labour, in spite of all the cruelty which the ingenuity of a tormentor could suggest. Children were often worked sixteen hours a day, by day and by night. Even Sunday was used as a convenient time to clean the machinery. The author of The History of the Factory Movement writes: "In stench, in heated rooms, amid the constant whirling of a thousand wheels, little fingers and little feet were kept in ceaseless action, forced into unnatural activity by blows from the heavy hands and feet of the merciless overlooker, and the infliction of bodily pain by instruments of punishment, invented by the sharpened ingenuity of insatiable selfishness." They were fed upon the coarsest and cheapest food, often with the same as that served out to the pigs of their master. They slept by turns and in relays, in filthy beds which were never

${ }^{1}$ Industry in England, pp. 389-390. 
cool; for one set of children were sent to sleep in them as soon as the others had gone off to their daily or nightly toil. There was often no discrimination of sexes; and disease, misery, and vice grew as in a hotbed of contagion. Some of these miserable beings tried to run away. To prevent their doing so, those suspected of this tendency had irons riveted on their ankles, with long links reaching up to the hips, and were compelled to work and sleep in these chains, young women and girls, as well as boys, suffering this brutal treatment. Many died, and were buried secretly at night in some desolate spot, lest people should notice the number of the graves; and many committed suicide. The catalogue of cruelty and misery is too long to recite here; it may be read in the Memoirs of Robert Blincoe, himself an apprentice, or in the pages of the Blue-books of the beginning of this century, in which even the methodical and dry language of official documents is startled into life by the misery it has to relate.

So late as the ' 40 's, by the same authority: ${ }^{1}$

'We hear of children and young people in factories overworked and beaten as if they were slaves; of diseases and distortions found only in manufacturing districts; of filthy, wretched homes, where people huddled together like wild beasts; we hear of girls and women working underground in the dark recesses of the coal-mines, dragging loads of coal in cars in places where no horses could go, and harnessed and crawling along the subterranean pathways like beasts of burden. Everywhere we find cruelty and oppression. ... Freedom they had in name;

\section{Page 423.}


freedom to starve and die; but not freedom to speak, still less to act, as citizens of a free state.

\section{RESULTS OF "CHEAP-LABOR" SYSTEM}

Such conditions cannot be explained entirely upon the ground that greed had suddenly made brutes of English manufacturers as a class. They were men of the same stamp and ancestry who had lived, in the main, in fair and friendly relation with their helpers in the domestic industries for hundreds of years. But the enormous and unaccustomed wealth machinery was bringing to these men blinded most of them to every consideration except that of profits, particularly as they felt themselves justified in this incredible inhumanity on the best of authority. By the standard economic teaching of the time labor must be cheap-the cheaper the better-if England were to win the commercial supremacy of the world. To the typical business man of the period no aim could be higher than that, especially as he saw the lion's share of the benefits of expansion coming directly to himself.

From that day to this there have been employers who have shaped their course upon much the same idea. The fact that low wages do not always mean low labor cost, but very often just the opposite, was seen by almost nobody and is not seen by everybody to-day. For more than a century the doctrine of low wages and a long working day stood as a first maxim of business success. On the strength of it, every attempt to raise wages or reduce the hours of labor was bitterly fought. 


\section{GROWTH OF CLASS HATRED}

It is little wonder that workingmen under these circumstances grew to think of the entire employing class as its natural enemy. The early German socialists had no trouble in making out a strong case, for if it were true that profits depended on keeping wages down and working human beings to the limit of endurance, the only hope for labor on the face of the thing would be to abolish capitalism entirely. Socialist and communist doctrines had their rise and first great wave of popularity, as one might expect, in the era before the rise of organized labor on the one hand and of competition on the other obliged capitalism to base its own success less and less upon the power to exploit, more and more upon a division of benefits with the community. However, only a fraction of the working-class population understood and followed the extreme radical teachings, even with the bitterness of early factory life to goad them.

For all practical purposes the wage-earner was helpless. What was to take the place of his old relation with the employer, with some approach at least to equality in bargaining power, now that he no longer counted as an individual but as a part of the new power mechanism merely, to be bought as cheaply as possible, used up and discarded as machinery is scrapped when it begins to lose efficiency?

What was left for him? The more enterprising could see only the chance that by acting together they might be able to compel some recognition as human beings. Where no notice would be taken of a single laborer, 
many unitedly refusing to work unless conditions were made at least endurable might be able to stop this degradation which bid fair to force English working people into a condition even worse than that of the serfs of the middle ages.

\section{EARLY IABOR UNIONS}

Unions of wage-earners were not entirely new. They had existed in some trades long before the factory system, and were distinct from the old craft guilds. English commerce grew very rapidly after the discovery of America, and one industry after another reached the point where more capital was needed than the ordinary artisan could supply. Such a man became, more and more, a wage-worker for others, and began to think of his welfare as allied more with that of his fellow workmen than of his employer. Trade unions, in the presentday sense, date back to this first clear separation between the employer, owning the tools and materials, and the workingman owning neither but selling his services for wages.

In the century before the industrial revolution unions of wage-earners grew up in a number of trades, chiefly the hatters, tailors, wool workers, silversmiths, gold beaters, hosiery workers and shipwrights. These.unions, it is true, were accustomed to stand with their employers on many matters affecting their trades, and on public measures, but about the time of the great inventions the doctrines of "freedom of contract and unrestrained competition" gained great headway, with the backing 
of the powerful new manufacturing class. Nearly all the legislation intended to regulate wage rates and apprentices or in any way to protect labor was swept away. The natural effect was to turn the wage-earners even more to combinations for self-defense. Instead of unions here and there in scattered trades, having little to do with each other, there grew up new bonds of common dependence and we had the beginnings of what we have known ever since as the "labor movement."

\section{AGITATION AND VIOLENCE}

But there were only two ways left open of voicing discontent-underground plots and open riots. Public meetings were sedition, combinations were criminal conspiracies. Most of the labor agitation of the early nineteenth century aimed at political power, as a means to regain industrial freedom and to bring the factories under control of law. The only results, for many years, were committees of Parliament, appointed to investigate and report. The reports were against doing anything, on the ground, as the Select Committee of 1811 put it, that there should be "no interference of the legislature with the freedom of trade, or with the perfect liberty of every individual to dispose of his time and of his labor in the way and on the terms which he may judge most conducive to his own interest."

The same argument, in quite the same language, has served down to this moment in opposition both to trade union policies and to nearly all laws protective of the labor of women and children, and of men in dangerous 
trades. But the industrial liberty these committees believed in was a liberty, apparently, for everybody except the workingman who desired to combine with his fellows to improve his condition. Already Adam Smith had remarked that: "We have no Acts of Parliament against combining to lower the price of work, but many against combining to raise it."

The first great strike of factory workers occurred in Glasgow in 1812. The cotton weavers had tried in vain to come to an agreement on wages with their employers. They turned to the old laws and demanded that the justices of the peace fix a fair rate. A table of wages was, in fact, drawn up, the workers bearing the expense, but the employers refused to abide by it. Some 40,000 operatives quit work, but in the midst of an attempted settlement three weeks later the strike committee was arrested, under the conspiracy law, and the leaders imprisoned. This ended the strike, and with it all further efforts of the workers to gain a voice in fixing the price of their own labor. Next year, in 1813 , the law for wage-fixing by judges was repealed. The regulations of apprentices were abolished in 1814 .

\section{THE HUMANE FACTORY LAWS}

But the agitation went on, with gathering force. The horrors of the factory system won to the labor cause some of the English landed gentry and a number of influential philanthropists, Lord Shaftesbury foremost. The Grand National Consolidated Trade Union, formed in 1833, while a short-lived affair, numbered at one 
time three-quarters of a million members. And the humane ideas of Robert Owen, worked out in his own mills, were a direct challenge to the belief that success for the employer depended upon treating labor purely as a commodity.

The first of the English factory acts, passed in 1802, did little or nothing for the unfortunate apprentices it was intended to help. In 1819 the labor of children under 9 , in cotton mills, was prohibited, and it was limited to 12 hours a day for children between 9 and 15. The ban on conspiracies was relaxed in 1824. The acts of 1831 and 1833 set up new factory hour limits and prohibited night work by any one under 18 . In 1847 came the first ten-hour law, applying to women and children, and in 1874 the age limit for child labor in factories was raised to 10 . The practical effect of these laws was to limit the working day for men as well, since machinery could not be run after the women operatives and children stopped work.

The Chartist movement, demanding for workingmen the right to vote, collapsed in 1848, after a ten-year agitation which spread over all England, but nineteen years later, in 1867, the suffrage was granted to workingmen. It was not extended to agricultural laborers, however, until 1884. In 1875 labor associations were relieved of prosecution under the conspiracy laws, so long used to suppress them, and the labor movement took its place as a recognized and continuing part of the industrial system of modern times. "When we look back upon the last half century," says Gibbins, one of the ablest of historians of English industry and 
labor, "we are inclined to wonder that trades unionists have been so moderate in their demands, considering the misery and poverty amidst which they grew up." 1

\section{THE ROOTS OF LABOR DISTRUST}

But in the course of this long and bitter struggle the idea of employer and wage-earner as naturally hostile, the prosperity of one meaning the degradation of the other, sank deep into the minds of the workers. Most of the economic theories that helped so powerfully the growth of this feeling have been discarded, indeed, long since, and the ideas and practices of the majority of industrial employers to-day probably would have seemed radical folly to their forerunners when the factory system was young.

Nevertheless, the fact ought not to be forgotten, in our judging of men and policies and aims of the labor movement as we know it, that the defensive and offensive measures of trade unionism which we oftenest criticize as narrow and tyrannical are in the main the bitter fruits, long in ripening, of an era of despotic misuse of the power of capital. That era has largely passed away, but with a legacy of distrust which still underlies and accounts for much that is hardest to overcome in the relations of employers and workingmen to-day.

${ }^{1}$ Industry in England, p. 421. 


\section{AMERICAN TRADE UNIONISM}

LoNg before the labor movement made itself felt in the United States the battle for political liberty had been won. Democratic government was established: property requirements for voting disappeared early in the nineteenth century. The few trade unions which sprang up after the Revolution, chiefly among tailors, shoemakers, carpenters and cordwainers, were more concerned with working conditions than with politics, but by 1830 labor was in politics on a larger scale, relatively, than it has been at any time since.

\section{FIRST POLITICAL VENTURES}

In part this was due to class feeling, stirred up by many efforts to outlaw the unions through court prosecutions based on the English common law against conspiracies. Agitators for a number of radical ideas joined the movement and helped along the drift to politics. Demands for certain reforms by law had been gathering force for years and furnished other planks for a labor party platform-free common schools, for instance; restriction of child labor, a ten-hour day in factories, mechanics' liens, the abolition of sweatshops, contract prison labor and imprisonment for debt. 
The movement won a few local successes and induced the leading political parties to support some of the labor demands, but it drew upon itself increasing attacks from all sides, and lost its driving power through constant disputes within the ranks over rival social theories. It did not outlive the Jackson administration.

Meanwhile, during this political upheaval, the neglected trade unions had so fallen off in numbers that the labor demands in matters of wages and hours were making no headway. It was a time of rapid growth of manufactures and trade; the position of employing interests steadily gained strength; "cheap labor" doctrines, as in England, held sway everywhere. By the early ' 30 's more than half the workers in textile mills in the Eastern States were women. In Massachusetts. fully 40 per cent. of the mill employees were under 16 years of age. Immigration was steadily on the increase, and so was the farming out of prison laborers under contract.

\section{WHAT THE WAGE-EARNER ENDURED}

By the testimony of eye-witnesses, factory life in the '20's and '30's was much like that in England. Says Dr. Richard T. Ely: ${ }^{1}$

The regulations of the factory were cruel and oppressive to a degree, I think, scarcely known among us at present. Operatives were taxed by the companies for the ${ }^{1}$ The Labor Movement in America, pp. 49-56. 
support of religion; habitual absence from church was punished by the Lowell Manufacturing Company with dismissal from employment, and in other respects the life of the employees outside of the factories was regulated as well as their life within them. Windows were nailed down and the operatives deprived of fresh air, and a case of rebellion on the part of one thousand females on account of tyrannical and oppressive treatment is mentioned. Women and children were urged on by the use of a cowhide, and an instance is given of a little girl, eleven years of age, whose leg was broken with a "billet of wood." Still more harrowing is the description of the merciless whipping of a deaf-and-dumb boy by an overseer. . . . At Mendon, Mass., a boy of twelve drowned himself in a pond to escape factory labor. The wages were small. The "United Hand-Loom Weavers' Trade Association of Baltimore" reported in 1835 that they could earn in twelve hours from sixty-five cents to seventy-one cents a day, which, they said, did not enable them to defray the expenses "of the schooling" of their children.

A woman's earnings in this period were estimated at less than $\$ 60$ per year. The wages of women in Massachusetts shoe factories ranged from 8 to 50 cents a day. The working day in factories varied from 12 to 15 hours. On street railways, commonly, it was 17 to 18 hours, and often not less than that on the steam roads. In Baltimore and New York it was the custom for bakers, once a week, to work not less than twenty-five hours in one shift.

A prominent New England insurance company, as late as 1849, refused to take any more applications from factories, on the ground that "such places have been 
the graves of other companies and we mean to avoid. them."

\section{LABOR'S BATTLE FOR FREE SCHOOLS}

Labor attempted to battle with these conditions, after its political venture, by again building up the unions. Then came the panic of 1837 , and new political experiments in the ten years of hard times following. Dissension over programs and policies again split these attempts into fragments, but the agitation for humane factory laws and free public schools went on and bore fruit. Indeed, the fight for universal popular education was carried on almost single-handed by the labor movement for many years, against the opposition of elements one would have expected to lead in such an effort. The feeling was strong with many manufacturers, and long persisted with some of them, that "too much education is dangerous." However, a few great humanitarians, William Ellery Channing and Horace Mann among them, threw their influence in support of the workingmen's efforts.

Free schools, of course, would amount to little where they were most needed if children as young as 6 and 7 years were taken into the mills. But the struggle to fix an age limit met the opposition it has faced at every step since. So also did the attempt to cut down the working day of women from 12 and 14 hours to 10 . By degrees the ten-hour day became the rule in a number of trades, by the direct efforts of the unions, but until 1874 every attempt to establish it by law was 
defeated. The whole theory of setting bounds to the labor even of children, in the interest of health and morals and of common humanity, was condemned as an "evil of foreign growth" and "interference with natural laws" which would be certain to drive industry out of the country.

\section{"PURE AND SIMPLE" UNIONISM}

In the prosperous years of the '50's workingmen turned once more from politics to so-called "pure and simple" unionism. Success this time set the movement at last firmly on its feet. Unions multiplied in all the manufacturing and trade centers. Several expanded to national organizations of their crafts, excluding politicians. These have stood as the first ventures of labor in the national field to outlive their infancy. The national unions of printers, molders, hat finishers, machinists and blacksmiths all date from the '50's. By 1870 there were national organizations in more than thirty crafts, and the total trade-union membership had risen to some 300,000 .

Organization went on rapidly during the Civil War, in spite of the absence of great numbers of union members, serving in the northern armies. The emergency demand for labor worked to the advantage of the unions, and by the close of the war the idea of bringing all the labor forces together in one national movement again found many followers. The "National Labor Union" was started in 1866, but it did not prove a mighty weapon for trade unionism. Under the leadership of 
William H. Sylvis its efforts were turned chiefly to the coöperative idea, and many experiments were made by workingmen of little capital and no managing experience. All of them failed.

The National Labor Union took a hand in the Chinese exclusion and the farmers" "greenback" agitations; it pressed the eight-hour day for government employees, which Congress granted in 1868. It took the first step to connect American labor with foreign movements by sending a delegate to the labor congress at Basle in 1869. His mission, mainly, was to explain to European labor our difficulties with immigration, which had increased tremendously under a law of 1864 , permitting alien laborers to be imported under contract.

\section{DISSENSION AND FAILURE}

But the National Labor Union soon proved itself a rope of sand, like all its predecessors. It was based upon city assemblies of labor, which had no such bond of common interest in a large way as had the national unions of separate crafts. The old disputes crept in, between the trade unions and socialistic elements which insisted on political action. After the collapse of the National Labor Union in the early '70's, and the hard times following the panic of 1873, the labor movement again fell to a low ebb. Added to unemployment and distress, employers in many quarters made a determined drive to break up the movement once and for all.

But the instinct of self-defense, unable to act through orderly unionism, found new outlets in secret organi- 
zations such as the Knights of Labor, and in violence. This was the period of the mine riots, the "Molly Maguires," and the great railroad strikes of 1877 , which many feared would end in the downfall of law and order and the break-up of society. In the midst of the turmoil another political movement suddenly took form, the "National Party" of 1878, made up of farmers and workingmen. It polled a great vote in one election but vanished as swiftly as it came. Prosperity was returning, and labor once more attempted to rebuild on trade-union lines.

\section{SOME PERMANENT GAINS}

Meanwhile, a few clear gains had been won. In Massachusetts the first Bureau of Labor Statistics in the world had been created, in 1869, through the efforts of the labor movement, to be followed by the United States Bureau of Labor in 1884, and later by labor bureaus of some nature in practically all the States. In Massachusetts also, after fifty years of agitation and with the help of a number of philanthropists, the labor movement was able to secure in 1874 the first ten-hour law in this country, for women workers and children under 18. Ten hours had been fixed as a day's labor for children under 12 by a Massachusetts law of 1842 . In 1867 employment of children under 10 was forbidden altogether; children between 10 and 15 could work not more than 60 hours a week, and then only if they had attended school at least three months in the year. 
Here were the beginnings of that great mass of State and national legislation for protection of the health, safety and industrial rights of wage-earners which to-day covers fully 300 subjects and requires, merely to summarize, more than 2500 pages of government digest.

After the labor chaos of the '70's, the reviving unions showed a strong disposition to center on industrial demands and relegate party politics to the rear. New ideas of organization on business principles were being worked out, which were to have a far-reaching effect. The cigar makers especially, under the lead of Adolph Strasser and Samuel Gompers, were building on a strong foundation of high dues, benefit features, and broad powers to the national organization over local unions.

\section{THE AMERICAN FEDERATION OF LABOR}

'At Pittsburg, in November 1881, delegates to the number of 107 from many national and local labor organizations formed a "Federation of Organized Trades and Labor Unions of the United States and Canada," which in 1886 became the American Federation of Labor. For the first time, a national labor movement was based upon the national organizations of the various crafts, as such, except where only local unions as yet existed. A membership tax of 3 cents per capita per year was levied to assure the expenses of the new movement, which amounted in the first year to $\$ 445.31$. There were no salaried officers. 
Among the platform demands of this historic convention were the abolition of conspiracy laws as applied to labor bodies, no employment of children under 14, compulsory education, uniform apprentice laws, prison labor reform, legislation against the alien contract labor system, a national bureau of labor statistics, a protective tariff, labor representation in legislatures, and legal incorporation for trade unions. The tariff demand was soon dropped, and in the light of later experience the Federation has taken the opposite view of incorporation, for reasons explained in another place. ${ }^{1}$

Samuel Gompers, a leading figure in the new movement from the beginning, became the first president of the American Federation of Labor in 1886, and has so continued with the exception of the year 1894 . Partly through his leadership, and partly because of the many failures of experiments upon other lines, the Federation for now forty years has held to the craft union basis. Tacitly at least, it has accepted the idea of capital as a co-producer with labor, although with immediate interests often far apart.

It has sought to build up permanent contract relations with employers, through collective bargaining. Its propaganda through the labor press, organizers and lecture bureaus has grown to large proportions. Its support has been given, morally and often financially, to innumerable contests of member unions. The national conventions of the Federation have served as a melting pot of labor opinion and frequently as a means

${ }^{1}$ See page 143. 


\section{0}

THE LABOR MOVEMENT AND THE FARMER

of focussing labor effort upon issues of general scope, such as the 8-hour day, maintenance or advance of wage levels, opposition to what it regards as the encroachment of courts through injunctions, and to all measures restricting the liberty of workmen to leave an employment when they so desire. It has declined to endorse the revolutionary programs urged in every convention by minority groups, and in so far as it has entered the political field it has been in support of or opposition to the candidates and platforms of existing parties.

\section{THE RAILROAD BROTHERHOODS}

Alongside the American Federation, workingmen on the steam railroads have built up four brotherhoods of great strength, maintaining agreements on wages and working rules with railroad managements throughout the country, and accumulating large insurance and pension funds. The engineers', conductors' and firemen's organizations date from the ' 60 's, the brakemen's (later trainmen) from 1883. The president of the engineers, Warren S. Stone, has become widely known in late years for his advocacy of the so-called "Plumb plan" for public ownership of railroads under joint government and workers' control, and for his interest in coöperative ideas. The engineers have established, in Cleveland, a coöperative bank with deposits in its first year exceeding $\$ 10,000,000$. The four brotherhoods have worked in harmony with the American Federation in many matters of common interest, but have remained independent of official connection. 
The period since the American Federation was formed has been one also of immense concentration of capital. Powerful employers' associations have come into being and contested with the labor movement every inch of ground. To get any results with a progressive program, the Federation and the brotherhoods have been obliged to match these tremendous forces, not alone in the industrial field but in the legislative and judicial.

Some of the largest unions have been obliged also, as in no other country, to absorb a steady stream of immigrants, speaking many tongues, bringing with them unfamiliar habits of life and race animosities, entirely ignorant of democratic methods and the meaning of ordered liberty. It has been necessary to accustom these aliens to the idea and practice of majority rule, within the unions, and of negotiating on a business basis with employers instead of attempting to annihilate them as "class enemies." Whether by choice or not, the unions in a sense have served the purpose of training schools in working democracy, which the late Carroll D. Wright regarded as a highly important contribution of the labor movement in the present stage of our industrial development, and one little appreciated.

TRADE UNIONS AND UNSKILLED LABOR

It has been said of the American Federation of Labor that it is made up chiefly of wage-earners in the 
skilled crafts and is not therefore a broadly representative working-class movement. The Industrial Workers of the World attack the Federation on this ground, as did also the Knights of Labor before them. In the earlier years it is true that the new Federation, struggling for its own life, felt that it had no means to organize unskilled and migratory laborers or to carry this easily replaced class of workers through a series of costly wage contests. Later on a different view was taken, and for many years now the literature used by Federation organizers has contained this plank: "To maintain high wages all of the trades and callings must be organized; the lack of organization among the unskilled vitally affects the skilled; general organization of skilled and unskilled can only be accomplished by united action."

The rise of the I. W. W. no doubt spurred the efforts of Federation organizers, particularly among mine laborers, textile workers and packing house employees. It is stated, in fact, that two-thirds of the money raised by the Federation for organizing purposes is spent on work among the unskilled, and that there are single locals affiliated with the Federation, such as the Chicago hod-carriers and building laborers, which exceed in numbers the entire membership of the $\mathrm{I}$. W. W.

The line between skilled and unskilled labor is not a sharp one. Probably it is true that many occupations are commonly thought of as "skilled" as soon as they become organized, which actually are little if any above the grade of common labor. The large proportion of skilled and semi-skilled trades in the American 
Federation may be due less to intention or neglect than to the practical difficulty of building up a continuing organization, dependent on regular payment of dues, among migratory and day laborers, largely aliens and illiterate. Even the I. W. W., working entirely in this field and with every appeal to class hatred, never has been able to hold together more than an insignificant membership.

\section{PUBLIC CONDEMNATION}

The American Federation has survived several waves of public condemnation. The odium of the Chicago anarchist riots of 1886 , for instance, was visited upon all labor organizations, lawless and law-abiding, without much discrimination. In the failure of the Homestead steel strike of 1892 and the four years of hard times following, the Federation weathered conditions such as had virtually crushed the labor movement in several earlier crises. By the time the 1907 panic arrived, its united stand against wage cuts proved so effective that the period was tided over with very little lowering of labor standards.

A sharp crisis arose over the trial of the McNamara brothers for the blowing up of the Los Angeles Times building in 1910. This tragedy was the climax of a bitter struggle going on in the West and Middle West chiefly, between the iron bridge workers and certain corporations particularly hostile to organized labor. The McNamaras at first declared themselves innocent, and a large number of unions throughout the country 
contributed to a defense fund to assure them a fair trial. After their confession, efforts were made to lay the crimes of these men at the door of the American Federation, but a Federal grand jury, after searching inquiry, exonerated its officials of any knowledge of the dynamiting conspiracy. Public opinion, upon the whole, never took the charge seriously, but recognized that the Federation always had condemned violence as suicidal folly.

\section{THE NATIONAI CIVIC FEDERATION}

Indeed, before this movement was twenty years old a considerable body of public opinion saw that here was a new type of labor organization and that apparently it had come to stay. The possibility of working: with it, in an effort for mutual understanding through conference grew upon many public-spirited citizens. Some of these represented large employing interests which were not convinced that the correct attitude on labor was to assume all demands unreasonable and stand against them on general principles. In the late '90's this more open-minded sentiment led to the formation of The National Civic Federation, as a common and public meeting ground for exchange of employer and labor viewpoints and the adjustment, so far as possible, of industrial controversies. Its first president, Senator Hanna, was a prominent exponent of the new employer attitude, in the management of his own large affairs. Later on, under the able leadership of Seth Low, with the support of a large board of busi- 
ness men and nearly all the national labor leaders, a further impetus was given to the ideas of collective bargaining and trade agreements. During the same period, boards of mediation and arbitration were set up in a number of States.

\section{LABOR IN POLITICS}

In the field of politics, the Federation of Labor in 1906 made an appeal to public opinion with a "bill of grievances" which it kept to the front for several years. Nearly all the legislation sought at the time has since been enacted, including the creation of the United States Department of Labor, and a definite recognition in law that "The labor power of a human being is not a commodity or article of commerce." The writing of that declaration into the Clayton anti-trust Act of 1914 was hailed as a landmark in the history of labor emancipation. It has become evident since that a general acceptance of this principle, in the legal relations of employers and workingmen, will be a matter of slow growth.

If the two-party system of effecting majority rule were to give way to "blocs," each standing for some one industrial interest or idea and urging its special claims instead of a general program of national policy, labor also without doubt would enter the political field as a separate group. Otherwise, for the present at least, it appears probable that the labor movement will continue to seek its political aims, as farmers for the most part have done, through existing channels. 


\section{IABOR IN THE WORLD WAR}

The question whether organized workingmen in this country place class interests or common citizenship first was put to the test at the time of America's entry into the world war. Both trade unions and socialists had been on record for many years against war and in favor of international action of some sort to prevent it, but the two movements took opposite views of the issues raised by the menace of Prussian militarism.

On March 17, 1917, a national labor conference in Washington, attended by representatives of nearly all the organizations in the American Federation of Labor and of the railroad brotherhoods, issued a declaration which analyzed the world war as a "struggle between the institutions of democracy and those of autocracy" and pledged the labor movement "in peace or in war, in stress or in storm ... in every field of activity to defend, safeguard and preserve the republic of the United States of America against its enemies whomsoever they may be." It called upon all fellow workers and fellow citizens "in the holy name of labor, justice, freedom and humanity to devotedly and patriotically give like service."

Throughout the war Mr. Gompers served as chairman of the Committee on Labor, in the Advisory Commission of the Council of National Defense. A large number of other leaders in the movement joined in the effort to back up the government's military plans with speedy production of the war materials upon which everything depended. They declined, however, to sur- 
render the protective labor laws and agreements which had been established in industry or by legislation up to that time, and in this stand they were supported by President Wilson. Labor representatives, both men and women, assisted further in the work of the food and fuel administrations and in the several war industry boards.

It was a task without precedent, in our time. If it did not succeed wholly in preventing labor troubles it should be said that, in the judgment of men most familiar with the division of sentiment throughout the country, both on account of race sympathies and pacifist propaganda, the war could not have been won without this massing of labor coöperation during the critical months.

Early in the war Premier Lloyd George, at Mr. Gompers' request, sent to this country a delegation of British labor leaders who, joined by a Canadian group, made a tour of important industrial centers in the interest of labor solidarity in the supreme effort. On a like errand Mr. Gompers made several trips to Europe. The American Federation's first vice-president, James Duncan, served on the Root Commission to Russia, in the interest of the allied cause.

At the close of the war the American Federation joined the labor groups of the allied nations in demands for a code of social justice to be embodied in the peace treaty. In the summer of 1919 it issued a Reconstruction Program, elsewhere summarized, ${ }^{1}$ which called for

${ }^{2}$ See page 103. 
a long list of progressive measures and for common recognition of certain principles of broad scope.

\section{THE WAVE OF RADICALISM}

The American labor movement did not escape the wave of radicalism in all countries which followed the war. Determined attempts to swing it to the "one big union" idea, with a revolutionary program, were renewed in many quarters. Such was the underlying. motive of the steel strike of 1919, according to one of its prime movers, W. Z. Foster. The Federation of Labor supported the strike, once launched, although Mr. Gompers and other of its chief executives advised against it as premature. The radical leaders responsible for it have since been dropped from the unionizing committee of the industry.

Thousands of workingmen in Seattle, in Vancouver and Winnipeg, captured by the "one big union" idea, threw these cities into turbulence for a few weeks, and attempted to set up virtually a soviet system. For the most part they have since returned to their former trade-union affiliations. "Outlaw" strikes in the railroad service, repudiated by the Brotherhoods, showed further the spirit of the moment. Mr. Gompers' leadership of the American Federation was challenged in the 1921 convention by John L. Lewis, head of the United Mine Workers, not upon the grounds many who supported him desired but unsuccessfully nevertheless. The several attempts since the war to launch labor parties have developed little strength so far within the trade-union movement. 


\section{COÖPERATION IN PUBLIC SERVICE}

Meanwhile, however, the Federation has been taking an increasingly actice part in public affairs. In the Unemployment Conference of 1921, in the Advisory Commission to the American Delegation in the Arms Limitation Conference, and more recently in the $\mathrm{Na}$ tional Conference on Agriculture, Mr. Gompers has represented, by appointment, the labor viewpoint. It is noteworthy that a definite move for disarmament was urged by the Federation at its Denver convention in June, 1921. The resolution called upon the government of the United States "to take the initiative or to coöperate with any other nation or nations for the purpose of a general agreement for disarmament both of the army and the naval affairs of the world," and declared it to be the duty of the Federation's executive council "to call upon the workers and the people to aid in every way within their power and to translate into action the sentiments recommended."

After the conference was called, Mr. Gompers took steps to form a General Committee of representative citizens, some two hundred in number, to aid in arousing public sentiment for the support and encouragement of the American delegation in its efforts for a genuine arms limitation program. The Federation itself coöperated with an extended publicity campaign through the labor press, pamphlets, demonstrations, and a speakers' bureau of several thousand members. Leaders in the movement urged special measures to provide employment for shipyard workers to be thrown 
out of employment by a naval holiday, but the fact that this displacement must occur did not weaken the labor stand in the matter. Mr. Gompers was quoted to the effect that "instead of being engaged in labor for the advancement of destruction, workers will be doing something that is constructive. It is a more constructive job to destroy a battleship than to build one, and $I$ believe that in actual numbers more men will be employed after this program goes into effect-if it is adopted by the nations-than are employed now."

The General Committee issued an appeal, further, that the United States call an international economic conference. This will be momentous, the committee declared, "in ushering in a new era of peaceful and friendly adjustment of international problems, and will be of the greatest consequence in removing economic barriers and consequent misunderstandings such as, in the past, have led to war."

\section{ORGANTZATION AND LEADERS}

The American Federation of Labor is organized much on the plan of the Federal government. Each of the trade organizations in its membership retains full control over matters arising within its own jurisdiction. The Federation has no power either to order or to call off a strike. Its executive council may lay a per capita tax to support a contest deemed to be vital, within a particular trade, but not to exceed one cent per week for not more than ten weeks in any one year, and very few such assessments have been actually laid. 
The headquarters are in Washington, D. C., where the Federation occupies a modern office building, dedicated in 1916. Its general work is maintained chiefly by a per capita tax of one cent per month per member (yielding at present about $\$ 540,000$ ), by subscriptions to its official magazine, and by contributions to special defense funds. For the last business year the expenses were about $\$ 850,000$, the largest single items being for organizing expenses, printing and publishing. The details of income and expenses are published in quarterly circulars and in the annual convention report. The national conventions are open to the public; the proceedings are reported and published verbatim, and are available to any one interested. In addition to the American Federationist, more than 300 periodicals are regularly published by the various member organizations.

Among the Federation leaders best known as spokesmen for the labor cause or in service on public boards and commissions, besides Mr. Gompers, are the former Secretary of Labor, William B. Wilson; Frank Morrison, secretary of the Federation; James Duncan, of the granite cutters; John L. Lewis, of the coal miners; Matthew Woll, of the engravers; James W. Sullivan, of the printers; Sara A. Conboy, of the textile workers; William H. Johnston, of the machinists; Hugh Frayne, of the sheet metal workers; John P. Frey, of the molders; Andrew Furuseth, of the seamen, and T. V. O'Connor, of the longshoremen.

There are represented in the American Federation of Labor at present 111 craft organizations of national 


\section{THE LABOR MOVEMENT AND THE FARMER}

scope, some extending into Canada, with a total of more than 36,000 local unions and a membership slightly under 4,000,000. The railroad brotherhoods, with about 450,000 members, and certain other unions not affiliated with the American Federation, bring the total unionized labor strength close to 5,000,000, estimated as about one-half of all the wage-earners commonly regarded as organizable in manufactures, mining, transportation and the mechanical trades. It is often pointed out, in reply to the criticism that the labor movement speaks for a small fraction only of the population, that five million members represent, on an average basis of wage-earners' families, not less than twenty-five million people. 


\section{$\nabla$}

\section{RADICAL MOVEMENTS IN THE UNITED STATES}

The line between trade unionism and revolutionary movements is much more sharply drawn in the United States than in Europe. There are of course many socialists and communists in the unions, and certain local unions are wholly controlled by them, but in the American Federation of Labor as a whole they are a small minority. The largest single union with a radical program, the Amalgamated Clothing Workers, is outside the Federation: it has a membership of about 175,000 , and demands complete workers' control of the industry.

As in Europe, membership in the radical or revolutionary political groups in this country is not limited to wage-earners. Some of their most conspicuous leaders are professional men, writers, and men and women of wealth giving their time to the propaganda. The socialist vote always greatly exceeds the enrolled membership of the party, indicating that many elements of unrest and discontent with existing conditions voice their protest in this way, in addition to those who know: just what the socialist program offers and fully accept it.

Because of the mixed membership of the revolutionary groups and their small following in contrast with 
the trade unions, it is more open to question in this country than it is abroad whether the "labor movement," as here understood, properly includes the socialist and communist parties at all. They do not particularly claim such a designation: indeed, the socialist program is urged as a social movement seeking its ends through political means, while trade unionism is an industrial movement seeking its ends in the main through economic means.

\section{THE I. W. W.}

The case is somewhat different with the Industrial Workers of the World, which is an industrial movement seeking its ends through revolutionary means. It is a loose organization, of uncertain strength, made up chiefly of unskilled and migratory workers. While a wage-earners' group, it is clearly set off from the trade unions by the fact that it does not propose to coöperate with the system of private industry but to overthrow it. Neither has it any faith in the socialist plan of state or collective ownership and management of industry. What it demands is complete control of industries and plant by the workers actually operating them; an idea long popular in French labor movements as "syndicalism," more recently taken up in England and America as "guild socialism," and, from still another angle, described by Emma Goldman as "in essence, the economic expression of anarchism."

Unlike the socialist program, again, the I. W. W. movement discards political methods as useless. It pro- 
poses to gain control of industries by "direct action," destroying the possibility of profits by incessant strikes and "sabotage"-that is, disabling machinery, slacking work and spoiling product. If these means do not bring the owners to abandon control to the operatives, the final step is to be forcible capture, as attempted in 1919 in many of the industrial centers of Italy. As a step to complete workers' control the I. W. W. attempt to organize all classes of wage-earners in "one big union," without regard to trade or occupation.

The I. W. W. organization was founded in Chicago in 1905. The preamble of its constitution declares that "the working class and the employing class have nothing in common. Between these two classes a struggle must go on until the workers of the world organize as a class, take possession of the wealth and of the machinery of production, and abolish the wage system."

The movement has been active chiefly in the Middle and Far West. The membership, probably never above 65,000 , and now very much less, is difficult to ascertain because of the "underground" nature of much of the organization's work. All the prominent strikes of I. W. W. origin, in western mining camps, in New Jersey, and in the Lawrence, Mass., textile mills in 1912, have been violent; and the organization has been in close touch with anarchist groups at various points. Some 95 of its leaders were sentenced, in Chicago in 1917 , for disloyal activities during the war, and the founder of the movement, William D. Haywood, is at present a fugitive from justice. The I. W. W. is not affiliated with the Third International and has not en- 
dorsed the Russian scheme for a universal soviet republic, but Mr. Haywood reported to the International in 1921 that: "The one single obstacle in the pathway of I. W. W. progress toward class unity is the American Federation of Labor."

\section{"ONE BIG UNION" VS. TRADE UNIONS}

The difference between the "one big union" idea and that of the trade unions is important and far-reaching. Under the former plan, a grievance leading to a strike on the part of any one of the many subdivisions of labor in a plant would take with it the entire force. Workingmen who thus go on strike repeatedly to assist employees in other departments naturally expect the same support in their own disputes. A steady succession of shut-downs brought about in this way could readily, of course, reduce an industry to bankruptcy. Once become a liability rather than an asset to the owners, so the theory goes, the workingmen can take possession unopposed. The particular grievance is a secondary matter so long as there are enough of them to bring about this end.

With the trade union, on the other hand, the special object sought by a strike is the important thing. It is looked upon as one more step in the gradual and permanent improvement of working conditions, or to gain the right to a voice in determining those conditions, but the purpose is not to capture or paralyze a plant as a means to revolution. The unions insist that practically everything labor has been able to gain by its 
own united efforts has come through organization by trades. For one thing, when men are so organized on a large scale, it is much more difficult for an employer to fill the places of workmen in a particular trade who are asking more for their labor. For another thing, members of a trade union are the more likely to realize that whatever affects their calling in one locality may affect it everywhere, and to give financial help to fellow members engaged in a contest, who otherwise would be left to make the effort alone. It is possible also, in this way, to unite a large proportion of the workers in a given trade, throughout the country, in some particular demand, such as the eight-hour day. If the demand is won, the very common effect is that unorganized plants by degrees concede it as well, in order to hold their competent help, so that the new system tends to become the standard for all workers at the trade.

It is urged on behalf of this method, further, that the bringing together of men of each trade, no matter where employed, tends to a larger sense of responsibility and a disposition to get what is possible at a given time rather than to wreck the industry, since workingmen regularly employed are loath to quit work in a succession of strikes on petty local issues arising at far distant points. Usually they are brought to the point of a general strike only when the issue is one of general concern and other methods have failed.

Whatever the merits or weakness of this "one thing at a time" plan, it appears to fit in with the economic fact that modern industry, with the help of science and invention, has been able to overcome piecemeal addi- 
tions to labor costs, brought about in this way, where it could not remain solvent in the face of simultaneous demands of all classes of workers, plant by plant, acting as "one big union." As a matter of fact, it has never proved possible to hold together workingmen of all trades in a series of such struggles long enough to accomplish important or lasting results.

\section{THE KNIGHTS OF LABOB}

The underlying ideas of the I. W. W. and the once powerful Knights of Labor have much in common. The Knights, organized in 1869 by Uriah Smith. Stephens, proposed to abolish the wages system and set up coöperative industries. For some years they operated as a secret order, with signs and passwords, in part to offset the spy and detective system used by employers to break up the trade unions. In the '80's, under the leadership of T. V. Powderly, the membership reached nearly three-quarters of a million. There were many trade unionists in the Order, but the majority were unskilled and migratory workers organized on the "one big union" plan without regard to occupation, and more or less revolutionary in temper.

In later years efforts were made to turn to the craftunion idea, but the stronger groups. were by this time deserting to the new American Federation of Labor. The Order was not limited to wage-earners, and it became the prey of politicians and sponsors for various socialistic and land-tax panaceas. Some legislation is to be credited to its efforts, notably the anti-contract 
labor law of 1885 , but its few political successes were short-lived and factional disputes finally wrecked the organization. Twenty years after the great strike of 1885 on the Gould railroads, the Knights' greatest success, only a few ineffective locals remained.

\section{COMMUNISM AND SOCIALISM}

In this country, the earliest schemes for rebuilding society on new lines were communistic. They were inherited in part from ideas born in the French revolution, in part inspired by Robert Dale Owen's crusade for industrial coöperation. A little later came the Fourier idea of "associations," producing and sharing in common, which enlisted some mighty champions in the generation before the Civil War-Greeley, Dana, Channing and Whittier among them. Some forty of these colonies were started, including the well-known Brook Farm community in Massachusetts. They all disappeared within a dozen years.

Socialism, as an exact theory of the common ownership of all industry, was planted here mainly by followers of Marx and Engels, driven out of Germany in the '50's. In late years, to a great extent, the name has been wrenched from its original meaning until many people apply it almost at random to all manner of humanitarian reforms, such as the shortening of the working day or abolition of sweatshops, child labor and kindred evils. The socialist movement always has resented this confusion of its central idea with measures which logically it regards as "patchwork." From this 
point of view, poverty and injustice are due to the system of private industry: the workers can make no -real gain so long as this endures, and attempts to improve it only delay its overthrow. In so far as trade unions are endorsed, it is only as means of training workingmen to carry on the future socialist state. There is a group of "intellectuals," however, allied with the socialist movement, who favor immediate reforms but regard them only as steps toward socialism.

\section{WHAT SOCIALISM MEANS}

There is little disagreement between the two schools as to what socialism itself, however brought about, actually means. One of the ablest of its advocates, Morris Hillquit, of New York, in his testimony before the Industrial Relations Commission in 1914, offered this much-quoted definition, which is substantially that also of the Socialist Party platforms:

The socialist program requires the public or collective ownership and operation of the principal instruments and àgencies for the production and distribution of wealththe land, mines, railroads, steamboats, telegraph and telephone lines, mills, factories and modern machinery. This is the main program and the ultimate aim of the whole socialist movement and the political creed of all socialists. It is the unfailing test of socialist adherence, and admits of no limitation, extension or variation. Whoever accepts this program is a socialist, whoever does not is not. 
This is the interpretation given also by the Intercollegiate Socialist Society, recently re-named the League for Industrial Democracy:

Socialists hold that to abolish these [stated] evils society must take possession of the socially used means of production and distribution, managing them democratically for the benefit of the entire people.

\section{POLITICAL SOCIALISM}

As a political movement in this country socialism dates from the formation of the Social Democratic Party in 1874, soon followed by the Socialist Labor Party in 1877. The movement drew little public attention until the '90's, when its leader, Daniel DeLeon, a man of force as a revolutionary agitator, brought its voting strength up to the high level of about 80,000 . Only wage-earners had been admitted to the Socialist Labor movement, but in 1901 the party split, largely on this issue. A faction joined itself to a new Social Democratic Party which had been organized by Eugene $\mathrm{V}$. Debs after the collapse of his American Railway Union. This party had given Debs 87,000 votes for President in 1900 . The groups so united were thereafter known as the Socialist Party, with Mr. Debs as its candidate in every presidential election since except that of 1916. During that period the party has elected two of its candidates for Congress, Victor Berger, of Mlinois, and Meyer London, of New York, a member of the present Congress. 
By 1912 the Debs vote very nearly touched 900,000. In that year a party membership of 120,000 was reported; by 1919 it had fallen to less than 110,000, and at the party convention of 1921 it was placed at about 17,000 . In 1920 , the normal increase in population and the addition of women as voters might have been expected to give Mr. Debs a vote approaching two millions; his actual poll was a little under 915,000.

The decline in strength is largely explained by the party's attitude during the war, and by the loss of a large communist faction after the war. In May, 1917, the socialist convention at St. Louis had adopted this resolution, later confirmed by referendum:

We brand the declaration of war by our government as a crime against the people of the United States and against the nations of the world. In all modern history there has been no war more unjustifiable than the war in which we are about to engage. No greater dishonor has ever been forced upon a people than that which the capitalist class is forcing upon this nation against its will.

In the following months the campaign carried on by prominent socialists and by the party press was considered obstructive of the government's war measures, including the draft, and upon these grounds many leaders, including Mr. Debs, were convicted and sentenced to prison. A group of "intellectuals," including Charles Edward Russell, J. G. Phelps Stokes, John Spargo and William English Walling, resigned from the party and 
formed the Social Democratic League, supporting the government upon the grounds already taken by the American Federation of Labor.

\section{NEW RADICAL GROUPS}

But after the war the new bolshevist wing attempted to carry the party farther than it cared to go. Certain sections were expelled. The socialist convention of 1920, it is true, had endorsed the Third International but without approving a "dictatorship of the proletariat." Because of this action the Moscow leaders denounced the Socialist Party as allied with capitalist society and an enemy of American workmen. The socialists promptly responded. At the party convention of 1921 speakers who had strongly championed the Russian revolution now denounced the soviet government as a "wrecking crew" and "murderers of the socialists of Russia." International alliances were repudiated.

Meanwhile the communist factions, meeting in Chicago in September, 1919, had formed the Communist Party, from which in turn, almost immediately, a considerable group seceded and formed the United Communist Party, which is officially approved by the Third International. Many of its members have been deported for activities having the avowed object of overthrowing the government.

Still another radical group, politically, is the FarmerLabor Party, which grew out of the formation of the Labor Party of Illinois in November, 1918. A year later the idea was carried farther and a national con- 
vention called in Chicago. More than one thousand delegates attended, representing various labor, farmer, coöperative and social reform organizations. A platform was adopted, in many respects like that of the British Labor Party, demanding nationalization of all public utilities and basic industries and of all unused land, abolition of the United States Senate, limitation of individual incomes, international solidarity of labor, and general disarmament. Taking the name of the Farmer-Labor Party in 1920, its candidate for President, Parley P. Christensen, received some 270,000 votes. The movement has won no official support from the American Federation of Labor, nor from the leading farm organizations.

Upon its heels there has come still another political venture of radical sentiment, the "Workers' Party," formed in New York in December, 1921, designed "to permeate the trade unions with truly revolutionary elements" and to "work for the establishment of a workers' republic" in the United States. The I. W. W. were represented at this convention, but promptly repudiated the Workers' Party as an enterprise not of actual wage-earners but of politicians.

Factional differences and party splits in the radical movement as a whole have been fatal to material political headway. The defeat in 1921 of four of the five socialist members of the New York legislature, who had been expelled and once reëlected, is credited to division among the socialist, communist and farmerlabor factions. However, the Attorney General of the United States in his annual report for 1921 gives warn- 


\section{RADICAL MOVEMENTS IN UNITED STATES 65}

ing that the underground propaganda of the Third International, through communist and other revolutionary groups in this country, is meeting with marked success in many labor unions. To whatever extent this is the case, the American Federation of Labor in resisting it will at least be on familiar battle ground. 


\section{VI}

\section{EUROPEAN LABOR MOVEMENTS TO-DAY}

The world war and the Russian revolution threw the labor movements of Europe very nearly into chaos, in Italy entirely so. The socialist parties especially, and the trade unions only less so, were torn with dissension between war-supporters and pacifists, the flaming partizans and bitter opponents of bolshevism. Trade unionists very generally and the majority groups of socialists dropped the international idea for the time being and stood by their home governments; they still remain strongly opposed to either the Russian program or Russian dictatorship. But the extreme "left wing" radicals, in every instance, broke off in new political and labor groups and are now working for world revolution through the Third International.

The year 1920 saw the crest of the wave. Discouraging events in Russia and the sudden end of the "war boom" in industry began to tell. A growing caution in the minds of German workingmen, the breakdown of the triple alliance in England and of the French railroad strike, the failure of efforts to fan the steel, coal and "outlaw" railway strikes in the United States into a general labor war, the Fascista movement in Italy, all marked a turn of the tide, not necessarily to reaction or surrender of aims but to other than revolutionary ways and means. 
Conditions are still highly unsettled. On the Continent especially there are frequent changes in party lines, leadership and policies. We are still too close to the shifting scene for an exact picture. Whatever one may say of the labor situation in European countries at the moment will be almost certainly disputed, according to the estimate placed upon each new departure by its partizans. It is only possible here to show the main divisions of the movement, the drift of the currents to-day, which may indeed set in quite another direction to-morrow.

\section{LABOR IN GREAT BRITAIN}

In the fifty years since trade unions were legalized, in Great Britain, they have grown to a membership of more than six millions. About one million are represented in the General Federation of Trade Unions, an organization formed in 1899 for advisory and educational purposes and to pay strike benefits. It does not include certain large unions, notably the railwaymen and the miners.

An earlier and larger body of British labor is the Trade Union Congress, dating from 1868, but with no distinct program other than to hold annual conferences and adopt resolutions on current issues. It has a parliamentary committee, looking after the interests of labor in legislative matters between the sessions of the Congress. The trade unions proper still form the underlying strength and supply most of the funds for labor activities in Great Britain, political as well as 
industrial, but in late years they have been much less in the public eye than the British Labor Party.

In 1899 the trade unions started a movement to secure better representation of labor interests in the House of Commons, and out of this effort has grown the Labor Party. Limited at first to wage-earners, it now admits all workers "by hand or by brain." The influence of a prominent group of "intellectuals" in the party appears in its demands and policies of recent years, many of which have little relation to what we usually have in mind as a trade-union program.

The Labor Party was reorganized in 1917, on account of war developments. It has now a three-fold membership of trade unions, socialist and coöperative groups, and individuals. There are represented in its national councils the Independent Labor Party with an outright socialist program, the British Socialist Party, dating from 1883 but of small political importance, the Fabian Society, founded in 1884, and the Woman's Labor League, demanding direct representation of women in Parliament.

There are also among the radical groups the "guild socialists," who propose that the government acquire by degrees all industries and public services, ultimately annihilating all claim of the private owners. Unlike the political socialists, they would have each industry or service managed directly by the workers who operate it. This latter idea is that, substantially, of the French syndicalists and the Industrial Workers of the World, but under the guild name it has attracted new attention. Apparently it is taken more seriously in the 
United States than in England, although the scheme of government ownership with workers' control has been for some time the program of the British coal miners, endorsed by the Labor Party.

The political strength of the British Labor Party has varied greatly; perhaps it is at present about 1,500,000 votes. There have been labor members in Parliament since 1874, when two were elected; twenty-five years later there, were eleven. At present the labor representation is seventy, in a House of Commons of 707 members. In $1906 \mathrm{John}$ Burns became the first labor member of a British cabinet, as president of the local government board.

The first coalition government formed during the war (1915) contained three labor members; there were eight in 1918, when the Labor Party demanded their withdrawal. Four obeyed; four remained, and were dropped from the party. The great mass of British workingmen loyally supported the war, although some of the most conspicuous leaders of the Labor Party maintained a critical attitude towards the measures of the government and repeatedly pressed it for statements of war aims. The labor members in Parliament voted against some of the war credits, but supported conscription, against the orders of a Labor Party convention. The party attempted to send delegates to conferences of labor and socialist groups from all the nations in conflict, including Germany, with the object of stopping the war.

Arthur Henderson, who resigned from the Cabinet when it disapproved the proposed Stockholm conference, 
is secretary of the Labor Party. Coming from the iron molders' union, he is regarded as a connecting link in the party between the trade unions and the intellectuals. Hardly less influential, and better known in this country, is James H. Thomas, secretary of the National Union of Railwaymen, a notable orator, and since 1900 a member of Parliament. Mr. Thomas strongly supported the government during the war, and visited the United States in 1917, delivering the war message of British labor to American workingmen. In 1921 he attended the Denver convention of the American Federation of Labor. He is president of the International Federation of Trade Unions, succeeding W. A. Appleton, the leading figure and general secretary for many years of the British General Federation of Trade Unions. One of the most popular men in the British movement is J. R. Clynes, who also stood with the government in its war measures and made a successful record as Food Controller. In the more radical group is Robert Smillie, head of the Miners' Federation; in the conservative, Havelock Wilson, head of the Seamen's Union. Among the intellectuals of the socialist wing are J. Ramsay MacDonald, Philip Snowden and Sidney Webb, the latter one of the founders of the Fabian Society.

\section{BRITISH IABOR PARTY PROGRAM}

The Labor Party thus states its objects:

To secure for the producers by hand or by brain the full fruits of their industry, and the most equitable dis- 


\section{EUROPEAN LABOR MOVEMENTS TÓ-DAY Y1}

tribution thereof that may be possible, upon the basis of the common ownership of the means of production and the best obtainable system of popular administration and control of each industry or service. Generally, to promote the political, social and economic emancipation of the people, and more particularly of those who depend directly upon their own exertions by hand or brain for the means of life.

In 1918 the party issued a reconstruction program under the title "Labor and the New Social Order," which has been widely discussed. In some quarters it was hailed as a far-sighted plan for the rebuilding of society; in others, minimized as a restatement of familiar ideas applied to a time of worldwide unsettlement. It is described by Sidney and Beatrice Webb as "from beginning to end essentially socialist in character." 1

This program, in its revised form, declares the task of social reconstruction to lie not in a "patchwork jerrymandering" of the capitalist system but in "a gradual building up of a new social order, based not on classes, subject races or a subject sex, but on the deliberately planned coöperation in production, distribution and exchange, the systematic approach to a healthy equality, the widest possible participation in power, both economic and political, and the general consciousness of consent which characterizes a true democracy."

It is held to be of supreme national importance that there should be no degradation of the standard of life of the population, but that "the standard of wages in all

2 History of Trade Unionism, p. 698. 
trades should, relatively to the cost of living, be fully maintained"; that the government, as the largest employer, should set a good example in this respect; that the existing legislation for protection of the standard of life and limitation of working hours in various industries, and for workmen's compensation, housing, public health and education, should be extended and universally applied; that the conditions, rules and customs won by trade unions before the war and temporarily. modified should be fully restored, and all restrictions removed on the right of workingmen to strike for restoration of these conditions; that compulsory arbitration should be limited strictly to the war period; that extensive government works be undertaken and other measures adopted to forestall periods of unemployment; that the government unemployment insurance be restored and increased in amount.

It is demanded further, in this program, that complete adult suffrage, with equal rights for both sexes, be established; that education be nationalized and made universal, on a basis of social equality; that the government undertake a campaign of house building throughout the country at public expense; that the coal mines be taken over by the government permanently and the supply of coal, iron and other minerals "henceforth be conducted as a public service (with a steadily increasing participation in the management, both central and local, of the workers concerned)"; that the entire function of life insurance be taken over by the state, "with equitable compensation to all affected"; that "the Government should resume control of the nation's agricul- 
tural land," by a combination of large government farms, small holdings made accessible to practical farmers, municipal enterprises in agriculture, and farms let to coöperative societies and other tenants "under covenants requiring the kind of cultivation desired."

In all industries left in private hands, it was demanded that the war control and publicity of the "processes, profits and prices of capitalist industry" be continued; that the "unearned increment" of land values be taxed so that the land itself "shall belong to the nation, and be used for the nation's benefit"; that in view of the enormous war debts "an equitable system of conscription of accumulated wealth should be put into effect forthwith," in the form of a direct graduated levy, not alone on income and profits, but on the private capital of every one who owns more than $£ 1000$. By these means the Labor Party program proposed to move towards the end, identical with that of socialism, of "the future appropriation of Surplus, not to the enlargement of any individual fortune, but to the Common Good."

\section{RECENT LABOR EVENTS IN ENGLAND}

It was freely predicted at the time this manifesto appeared that Great Britain would have a labor government within two years. The course of events since has been, instead, towards more conservative ideas of reconstruction. At the same time, the industrial depression and widespread unemployment have lessened the 


\section{THE LABOR MOVEMENT AND THE FARMER}

militant spirit of labor for the time being. In April, 1920, Arthur Henderson declared that never in his long association with organized labor had there been "such a general reluctance to embark in industrial conflict."

At that time the coal miners were on strike against wage reductions and the withdrawal of war-time control of the mines. The railway and transport workers were to have joined with them in a demonstration of the power of mass action. At the last moment this "triple alliance" abandoned the attempt, when the miners refused to discuss certain new proposals with the employers. The public very generally supported the government's plans to keep the industries in operation, as the feeling grew that the objects sought in the coal strike were more political than economic.

It is quite possible, therefore, in this instance at least, that the effort to force the mines into the hands of the government, as proposed in the Labor Party program, were a principal cause of the dissension and loss of public support which led to a settlement on terms very unlike the original demands. Some of the British labor leaders have urged that the outcome of this struggle illustrates a serious weakness in the effort to advance labor interests chiefly through separate political action, in that it arouses against labor not alone the employer element, to be reckoned with anyway, but the hostility of other political, industrial and consumer interests in the community which might otherwise remain at least neutral.

However, the political movement of labor in England. 
is as yet too young to warrant final conclusions on the part it is to play. The Labor Party commands thus far the political support of barely one-fourth of the organized wage-earners of Great Britain. Most of its proposals are of a sweeping nature, and it is not clear how, if at all, some of them can be reconciled with the freedom of private initiative and security of ownership in property which the English race fought through many centuries to establish. On the other hand, the Labor Party refuses to commit itself to the revolutionary program of Russian communism. 'At the last general conference of the party, in June, 1921, an application from the Communist Party for admission to membership was refused by a vote of almost twenty to one, after a hot debate. The arguments which apparently settled the question were, that the Communist Party is affiliated with the Third International, its members pledged to take their orders from Moscow; that it enters any political group, not with the idea of observing its decisions or aiding in its policies, but to capture it for the revolutionary movement; that it stands for dictatorship of the proletariat, demands an armed militia of workingmen, and seeks its ends by force.

\section{LABOR IN FRANCE}

Political socialism always has played a larger part in French labor activities than in either Great Britain or the United States. The industrial labor movement found itself soon after the legalizing of trade unions in 1884. They had been forbidden under severe penalties 
ever since the French revolution, although indulged for a time by Napoleon III. as a means of winning the support of labor elements for his unsteady throne. After the Paris Commune of 1871, violent measures were again taken to suppress unions. They reappeared, by degrees, and a series of national organizations followed, torn by rivalries and largely controlled by socialists.

It was not until 1895 that a permanent body of French wage-earners as such came into being. The General Confederation of Labor, formed in that year, excluded politics but approved the idea of a general strike to bring about direct control of industries by the workers engaged in them. Before the war the General Confederation never had more than 600,000 members; it has now upwards of two millions. During the war it gave its aid unreservedly to the government, and since the war it has stood firmly against bolshevism : the Council of the Confederation confirmed this position, in February, 1922, by the almost unanimous vote of 92 to 3 .

It was drawn into the strike to force nationalization of the railroads, however, during the high tide of radicalism early in 1920. The General Confederation at first condemned this attempt, foreseeing failure, but endeavored to gain some concessions from the managements. The object of the railwaymen was not concessions but full control, and on this issue public opinion was against them. The General Confederation at length called a general strike on all French railroads, but the government drafted the strikers into military 
service, thousands of civilians volunteered to take their places, and the movement collapsed.

In November, 1918, the General Confederation of Labor put forth a reconstruction program, demanding a League of Nations, reparation but not reprisals, general disarmament, a place for labor at the peace table, an international labor congress, workingmen's representation in industry, the eight-hour day, compulsory education, national economic councils on reconstruction, with labor members; "collective control as opposed to private ownership of everything pertaining to the general welfare"; government control of production, profits, insurance, wages and labor conditions; no discrimination against union workingmen or foreign labor, and reduction of the national debt by taxes on income, war profits and inheritances.

\section{FRENCH SOCIALISM}

The French socialist movement increased its voting strength heavily after the war, polling some 1,700,000 votes in 1919. A large faction has since gone over to communism, affiliating with the Third International in 1920. This group is now known therefore as the French Communist Party: the more moderate elements continue as the Socialist Party, with a smaller membership than the communists but a larger delegation in the Chamber of Deputies.

The influence of the war in bringing all labor elements into closer relations for the time being has had the after effect, except among the communists, of a 
stronger disposition to rely upon political reform measures and negotiations with employers in regard to industrial conditions. Before the war a large proportion of the French peasantry and many wage-earners as well were small investors of savings, and these naturally have been slow to join movements looking to the confiscation of private property. Leon Jouhaux, the leading figure in the General Confederation of Labor, has declared recently that the time for revolutionary phrases is past, the time for practical reorganization is at hand. It was Jouhaux who urged French workmen and employers during the war to join hands for: "Maximum production in minimum time for maximum wage."

Both Jouhaux and Albert Thomas are of the moderate wing in French labor and socialist movements. M. Thomas, minister of munitions during the war and now director of the international labor office set up by the Treaty of Versailles, is perhaps the most influential of the conservative leaders. At the other extreme is the majority socialist leader Jean Longuet, a grandson of Karl Marx, and bitter critic of the government's war policies. It is an interesting circumstance that President Millerand and former Premiers Viviani and Briand, all three, were in their earlier and more radical years prominent in the socialist movement.

\section{GERMAN LABOR AND SOCIALISM}

As in other countries on the mainland of Europe, the labor movement in Germany was chiefly political rather than industrial, for many years after the revolutionary 
uprisings of 1848. That is, the ends desired were sought more through government means than by direct pressure upon employers. In Germany especially, the home of the famous socialist leaders Marx, Engels, Liebknecht, Bebel and Lassalle, the early workingmen's movement was almost wholly socialistic. It took permanent form in 1863 in the Universal German Workingmen's Association, followed soon after by the Union of Workingmen's Associations, both groups uniting in 1875. This "Social Democratic Party," so formed, by the time of the world war had attained a membership exceeding one million, with a voting strength of nearly six millions and 113 members in the Reichstag.

The Independent Socialist Party, a more radical group, formed during the war, had in 1920 a membership of 850,000 and a voting strength approaching five millions. It endorses the Russian program but has refused to connect itself with the Third International. A large section has deserted to the Communist Party, which in Germany is an outgrowth of the Spartacus League, well remembered for its violent outbreaks during and soon after the war. The voting strength of the Communist Party in 1920 was a little under 450,000. In August, 1921, the dues-paying membership was reported at about 161,000. 'A still more radical element has since separated from this group and formed the Communist Labor Party, but with a very small following.

Trade unions proper, in Germany, were of little importance until after the repeal of the laws against combinations, in the '60's. They were independent of the 
political socialists, but on many measures of public policy in more or less close relation with them. The German unions make much of the education of their members; they support educational work among the various trade groups, as well as a free trade-union school in Berlin.

In 1921 these so-called "free trade unions," composing the General German Trade Union, numbered about eight million members. The "Christian trade unions," standing for just conditions of labor and moderate social reforms, together with certain unions of public employees, form another group with a membership in 1920 exceeding one million. Among the minor labor bodies are the "Hirsch-Duncker" unions, believing in harmonious relations with employers, and a small body. of so-called "yellow unions," organized by employers within their own plants.

Both the trade unions and the socialist movement in Germany supported the government at the outbreak of the war, a course on their part bitterly condemned by socialists and labor bodies in other countries. The unions declared an industrial truce with the employers, and the socialists in the Reichstag immediately voted for the war credits. Nevertheless, disagreement arose within the ranks and led to the formation in 1917 of the Independent Socialist Party, a group which the government suppressed by force so far as pcssible.

RECENT AIMS OF GERMAN WORKINGMEN

Both trade unionists and socialists, during the revolution following the armistice, formed "workers and 
soldiers councils," not so much with the Russian idea of taking over the government as to control it. These councils practically disappeared with the adoption of the new German constitution. In their place, although quite unlike them in purpose, have come the "works councils," formed under the law of January, 1920, whereby councils of employees may be created in any industrial plant employing more than twenty people, with the object of "looking after the interests of the workers in the fulfilment of the purpose of the works." One or two members of these councils may sit on the board of directors of the company, to represent the views and wishes of the employees. There has been a struggle to develop these new councils along the lines of trade unionism, in spite of a determined effort of the socialists to prevent this.

The latest Reichstag elections have shown a considerable loss to both the majority and the independent socialists and a gain to the conservative groups. The demand for general and immediate taking over of all industries by the government apparently has lost some of its popularity. A German labor writer, L. Krause, says of the state of mind of German trade unionists in 1918 and 1921:

At the beginning almost all of them were on principle in favor of socialization, but very soon the conviction broke through that socialization to such an extent as the independent social democracy wanted was not practicable, considering that the future lucrativeness of the concerns to be socialized was not to be disregarded. Various under- 
takings brought up by the state or by towns since the revolution, such as tramways, have been working with great losses since that time. And so have the post office and railway administrations which announced deficits of many milliards. In the course of the discussions about the question of socialization most trade unions agreed in recognizing the particular difficulties to which it would give rise in their own branches of industry, but, on the other hand, they declared other industries, especially mining and metal works, ripe for socialization. Finally they declined a general socialization as being inopportune and voted in favor of developing "working communities."

Since the death of the socialists Karl Liebknecht and Kurt Eisner, and of Karl Legien, for thirty years leader of the free trade unions, the outstanding figures in the German working-class movements are not well known outside of Germany. Many of them hold official positions in the present government, notably Gustav Bauer, vice chancellor. Karl Kautsky stands foremost among the radical leaders.

\section{LABOR AND REVOLUTION IN ITALY}

The labor struggle in Italy, as an organized movement, dates from a congress of printers at the time of the revolutions of 1848. Various federations of unions, by trades, and local chambers of labor which arose later in many Italian cities, united in 1905 to form the present General Confederation of Labor, with a membership difficult to learn in the present chaos of the Italian 
labor situation. Probably it approaches two millions, or four times its strength before the world war.

While the Italian unions deal directly with employers, in the effort to force concessions, their general program is socialistic and they have an understanding with the Socialist Party whereby the political proposals of labor are supposed to be handled by the party while the latter lends its help to the trade unions in their industrial struggles.

A faction of the trade unions opposed to political action but favoring general strikes to gain complete control of industry for the workers broke away from the General Confederation in 1912 and formed the Italian Syndicalist Union, with a membership recently of about 150,000. Some of the largest trade unions in Italy, the railwaymen, seamen and port-workers, are not connected with the General Confederation but are strongly inclined to the syndicalist idea. The movement does include, as in no other leading European country, a large union of agricultural laborers, to the number of nearly 800,000 . Italy's agricultural population is almost double its industrial.

The Italian Socialist Party, dating from 1892, towards the end of the world war adopted the Russian communist program. In 1919 its candidates carried more than one-fourth of the communes in Italy, although the actual enrolled membership probably did not exceed 200,000. A bolshevik organization mainly, it has nevertheless declined to accept the orders of Moscow on the question of control of its own membership, and therefore has not joined the Third International. 
On this issue about one-third of the membership seceded and has formed the Italian Communist Party, with a program much like that of the Anarchist Union. Outright anarchism, in fact, has had an active following in Italy and some influence in nearly all the labor groups during the half century since Bakunin sowed the seed of violent revolution broadcast through Europe. The movement at present is suppressed by the government and its leaders are in prison.

A small group of conservatives left the Socialist Party on the general war issue and took its stand with the government, two of the leaders entering the Cabinet. The majority of the labor elements, both in the Socialist Party and the trade unions, opposed the entry of Italy into the war and attempted to remain "neutral" throughout. The radical unions were represented at the Zimmerwald socialist and pacifist conference in 1915. Bolshevik agents from Russia were active in Italy from 1917 on, and some of the Italian leaders were arrested and convicted of inciting riots at a time of national peril.

The Socialist Party and the General Confederation of Labor united in a reconstruction program, in 1918. It demands continuance of the "class struggle" as an international movement of the workers; universal disarmament, various administrative reforms, nationalization of water-power and minerals, a general insurance system, energetic taxation of inheritances and the gradual socialization or taking over by the government of all land; universal compulsory education, a minimum wage, eight-hour day and other protective labor legis- 
lation, to be based upon "effective acknowledgment of the right of all workers to a decent and human existence."

COMMUNISTS AND FASCISTI

All moderately radical programs were swept away after the war in a wave of revolutionary uprisings over the greater part of Italy, particularly in the north. Strikes were incessant, usually with violence; railway and telegraph service was repeatedly stopped and city lighting systems were cut off. Interdicts were issued, virtually denying the means of life to citizens who refused to accept the regulations of the socialist leagues. Industrial plants were taken by force, and the attempt made to operate them by soviets of the workers.

But control of the factories did not mean control of either raw materials or markets, and the experiment led almost immediately to shut-downs, unemployment and distress. The government was able to bring about an agreement between the metal workers and employers in northern Italy on a plan of "trade-union control," which never went into effect, however. A government measure took its place, more on the lines of the works councils in Germany.

Meanwhile, violent excesses brought on the violent counter-attacks of the Fascisti. Socialist headquarters and printing plants were wrecked, strikes broken and revolutionary meetings scattered. The Fascisti movement, made up of ex-soldiers, students, middle-class business men and non-socialist workmen, was no doubt 
assisted by employing interests and certainly was not discouraged by the government, but it is hardly probable that it could have swept the country except as a spontaneous revulsion, in the main, against the forcible attempt to overturn the government and set up a Russian soviet system in Italy.

In the riotous May elections of 1921 the National Union Party (anti-socialist) and the clericals returned 374 members of the Italian chamber of deputies, the socialists 140 and communists 15 , a reduction of 16 in the total representation of revolutionary groups. The socialist and labor movements have been so weakened by the breakdown of the expected revolution, the conflict with communists within the ranks and attacks of the Fascisti without, that for the present at least they are of little influence in the shaping of reconstruction policies, except as a latent threat. There has been recently a steady drift within the Socialist Party towards the "right wing," or less revolutionary group.

Leaders of the conservative following in the Italian socialist movement are Filippo Turati and Leonida Bissolati, the latter a cabinet minister during the war, and founder of $L^{\prime} A v a n t i$, the leading Italian socialist paper. Foremost in the revolutionary wing are the secretary of the Socialist Party, Constantino Lazzari, and Menotti Serrati, who was imprisoned in war time on the charge of sedition and at present is editor of L'Avanti. The picturesque anarchist, Enrico Malatesta, of noble family, agitator and plotter all over Europe, is now in exile. 
LABOR IN OTHER EUROPEAN COUNTRIES

In Belgium the trade-union and socialist movements are closely allied. During the German occupation the organizations were kept alive by refugees in France, Holland and England, working as a unit in behalf of victory for the allied cause. The labor movement of Holland is best known through the secretary of the Federation of Trade Unions, Jan Oudegeest, who is also secretary of the International Federation of Trade Unions. Of the labor movement in Spain, and most of the small nations of central and southern Europe, it may be said that they have little of trade-union organization as we know it but are largely revolutionary. In Spain, at least, this may be explained in part by the backward state of industrial development, the government ban on normal labor activities, and propaganda from the strong socialist and communist movements in other European countries. Most of the labor struggle that comes to the surface in Spain takes the form of anarchistic outbreaks on the one side and military suppression on the other.

Trade unions in Russia, repeatedly suppressed under the czars, made a sudden and rapid growth after the revolution of 1917. Under the bolshevik régime they exist merely as agencies of the soviet system, without the right to strike and with none of the independent powers of bargaining on terms and conditions of labor, exercised by members of trade unions in countries where organization of labor is free. 


\section{VII}

\section{INTERNATIONAL LABOR RELATIONS}

The idea of common action by wage-earners of all countries took form in a definite way in 1864. In that year the "First International" was organized in London, on a plan drawn up by Karl Marx. By 1870 the movement included labor groups from most of the European countries and the United States. The earlier efforts were limited mainly to aiding labor struggles in any one country by contributions from the trade unions of other countries, but in 1869 the socialists gained full control and demanded, as a first step, collective ownership of land. The First International was wrecked by a violent dispute between the followers of Marx and of the anarchist Bakunin, and by the fall of the Paris Commune, in which it had taken a leading part.

\section{THE SECOND INTERNATIONAL}

The Second International was formed in Paris in 1899, and during the next fifteen years it held nine congresses. It was always strongly under German influence, and leaned to reformist measures more than to revolution. "The final aim is nothing," Edward Bernstein declared: "the movement is everything." The program of the Second International pledged the socialists of all nations against war under all circum- 
stances, but all the majority groups in 1914 supported the war measures of their home governments.

Thereupon the Second International, for the time being, practically ceased to exist. Some of the minority factions continued to work against war, on the theory that it was purely a capitalist affair. A conference of labor and socialist delegates holding this view was held at Zimmerwald, Switzerland, in 1915; the attempt was made to hold another at Stockholm in 1917, but without result on account of the refusal of the British, French and Italian governments to grant passports. The French socialists and the British Labor Party endorsed the Stockholm project but the American Federation of Labor condemned it, on the ground that attempts to negotiate with labor groups of enemy countries could have the effect only of delaying or imperiling the outcome of the war. It held that neither democratic civilization nor the future of the labor movement could be secure until Prussian militarism was destroyed. The American Federation took part, however, in a conference on war aims, of labor and socialist groups of the allied nations, in September, 1918.

An attempt to revive the Second International was made at Berne in 1919, and at Geneva in 1920. The Geneva meeting, chiefly of British and German delegates, put forth a new platform of socialism to be achieved through labor control of governments, and condemned the Russian program of terrorism, dictatorship and suppression of democracy. The British Labor Party is endeavoring to rebuild the Second International, which still holds also the majority socialist par- 
ties of Germany, Belgium, Holland and Sweden. 'At the Amsterdam meeting of the International, in 1921, it was attempted to bring about joint action with certain other labor and revolutionary groups, on reparations, but without result. The American Federation sent no delegates either to Geneva or to Amsterdam, on the ground that the Second International, while hostile to bolshevism, nevertheless aims to overthrow the system of free industry and labor and establish state socialism, a program the American Federation has opposed for many years.

\section{THE THIRD INTERNATIONAL}

The Third International was formed at Moscow in March, 1919, to carry on throughout the world the Russian propaganda of revolution by force. Besides the bolsheviki, the Norwegian Labor Party and the communist groups of Germany, Hungary and other central European countries were represented. At the second meeting, also at Moscow, in July, 1920, delegates of revolutionary parties were present from nearly every country on the Continent. This congress repeated the familiar bolshevik demands for the overthrow of capitalism, dictatorship of the proletariat and an international soviet republic.

It was at this meeting that the much discussed "twenty-one conditions" of membership in the International were adopted, the net effect of which has been, in every country, to widen the split between the extreme revolutionaries and the socialist groups which object to turning 
over control of their internal affairs to the Moscow leaders. The congress declared that: "The class struggle in almost every country of Europe and America is reaching the threshold of civil war," and according to a leading American socialist the whole scheme of organization of the Third International is based on this "fantastic assumption." 1

In the European socialist groups, the reports of investigators of their own persuasion, returning from Russia, have turned sentiment strongly against the type of social reconstruction there in force. In 1920 the American Federation of Labor, in convention at Montreal, repudiated the Russian program in this resolution:

That the American Federation of Labor is not justified in taking any action which could be construed as an assistance to, or approval of, the soviet government of Russia as long as that government is based upon authority which has not been vested in it by a popular representative national assemblage of the Russian people; or so long as it endeavors to create revolutions in the wellestablished, civilized nations of the world; or so long as it advocates and applies the militarization of labor and prevents the organizing and functioning of trade unions and the maintenance of a free press and free public assemblage.

\section{INTERNATIONAL TRADE UNIONISM}

Regular relations between trade unions of different countries sprang from the First International, which

${ }^{1}$ From Marx to Lenin (Hillquit), p. 148. 
rapidly drifted into a socialist rather than an industrial labor movement. It was not until 1901 that an International Trade Union Secretariat was formed, at Copenhagen, to hold conferences every other year of the national secretaries of trade-union centers. In 1913 this organization became the International Federation of Trade Unions, with a membership estimated at more than seven millions, in twenty-one countries, including the United States. The Federation did not put forth a common program for the trade unions of all countries. It exchanged information and financial help and appeals, and advocated social legislation in behalf of labor. Political issues were debarred. Besides this general movement, there have been and are a number of international associations by separate trades or industries, having much the same objects and methods.

The International Federation went to pieces during the war, but was reëstablished at Amsterdam in July, 1919, with fourteen countries represented. The American labor movement was affiliated with the International Federation until 1915, and was represented at the Amsterdam conference; it has declined thus far to renew its connection because of programs and policies adopted, under political and socialist influence, which it regards as revolutionary and as attempts to dictate the course of national labor bodies. The Denver convention of the American Federation, in 1921, declared itself "impressed with the great need of lending all possible assistance to the trade-union movements of other nations" and as ready to affiliate with the International Federation "whenever the laws are amended so as to preserve 
the integrity, the right to self-government and determination on the part of each trade-union center."

In evidence of the attempt of controlling elements in the International Federation to commit the trade-union movement in all countries to a revolutionary program, there was cited a manifesto issued in the name of the Federation in 1920, headed: "Down with Reaction! Up with Socialization!" demanding socialization of the means of production as the "one aim on which they must focus all their efforts." A declaration has been made also for "mass action by means of a general strike" against war. American opponents of this proposal point out that with no better guaranty of united action than a similar idea afforded in 1914, such a pledge could have the effect only of putting the countries whose working. men lived up to it at the mercy of any war-making nation in which the strike was not carried out.

From the bolshevist standpoint, on the other hand, all labor movements which oppose proletarian dictatorship are betrayals of the worker. There was formed, in July, 1920, a "Red International Council of Trade Unions," with headquarters in Moscow, expressly to wage war against the International Federation of Trade Unions and the International Labor Bureau created by the peace treaty, and to turn the trade-union movement in all countries to revolutionary communism.

\section{IABOR AND THE LEAGUE OF NATIONS}

In the Treaty of Versailles it was sought to provide an outlet for the common aspirations of labor by an 
international bureau, to advise the member nations on suitable measures of uniform legislation for maintaining fair and humane labor standards. There had been treaties among various European nations covering uniform laws on certain conditions of employment, espocially affecting health, but in no previous general treaty of peace had the needs of labor been deemed important enough for special attention. The Versailles Treaty expressly justifies the labor clauses on the ground that the social unrest growing out of the hardships and injustices of wage-earners may imperil the peace of the world. The international labor office is founded, therefore, on the principle, as the treaty reads, "that the well-being, physical, moral and intellectual, of industrial wage-earners is of supreme international importance."

The principle of free association of labor is recognized, as well as the desirability of regulation of working time, prevention of unemployment, provision for a living wage, protection of children and women, vocational education, and insurance against sickness, injury and old age. The international labor office is in charge of a governing body of twenty-four members, twelve representing governments, six representing employers and six representing employees; while its annual conferences are made up of two government delegates, one labor and one employer from each member country.

The United States has no membership in this bureau, but the first meeting nevertheless was held in Washington in the fall of 1919, with thirty nations represented. Several countries sent only government delegates; less 
than one-half were employer and labor representatives. A number of recommendations were agreed upon, bearing on the health and working conditions of labor, and including the question of immigration. Further proposals were adopted at the second and third conferences (Genoa 1920 and Geneva 1921). Great Britain has ratified four of the six proposals of the Washington meeting, but not the most important one, providing for the eight-hour day. Some of this legislation has been passed in thirteen countries; about half of the fortynine member nations have not as yet carried out the treaty pledge to submit the agreed recommendations to the competent authorities for action. At Geneva the most important debate turned on the question how to induce the various governments to put in force the conference's decisions, and very little light was shed on the question. It was openly declared by some of the delegates representing workingmen that continued inaction by the governments would destroy the confidence of labor in the international office.

Two years before, at the Washington conference, Mr. Barnes, of the British delegation, had pointed out that the compelling force behind the recommendations would be that of public opinion in every country. Thus far, apparently, public opinion has shown no such interest or agreement in support of the conference proposals as would be necessary to carry out the really important reforms not already in effect in leading industrial nations. Even among the great labor groups represented in the international office there is a deep-seated reluctance to give over to any hands other than their own the 
choice of policies or of methods for enforcing plans of labor betterment. The French labor leader, Albert Thomas, himself director of the international office, insisted at the Washington conference that the work of reconstruction must be "carried out with the aid of the great trade unions," and E. John Solano, formerly. of the British ministry of labor, while favoring uniform standards of labor legislation in all countries, takes the ground that enforcement will depend on the power of organized labor.

The present prospect is that the international labor office will serve more largely as a means of investigation, information and exchange of ideas than as a controlling influence on labor legislation. Agreement upon uniform standards, among nations of very unlike conditions and in many different stages of industrial development, offers many serious difficulties. Probably there must come first, especially in the less advanced countries, a further working out of the labor movements in contact both with employers and the governments. 


\section{VIII \\ WHAT DOES LABOR WANT?}

WE have been following the struggle of industrial labor in modern countries, through many years, and gathering an idea of its present strength, its aims and methods. How shall we account for the tremendous extent and energy of the movement to-day? The most appalling conditions that helped to drive wage-earners together in self-defense a century ago have passed away. What is it that gives us an immensely stronger labor movement now, and in the very countries especially where the wage-earning population already has made the greatest advance in general conditions of life and work? What is back of it all?

\section{THE MEANS OF ADEQUATE LIFE}

The common instincts of all humanity are back of it, in the first place. It is absurd that we need to remind ourselves of this, whenever we discuss the labor question. What the wage-earner wants and what he maintains a labor movement for is, in the great essentials, what the farmer, business man, financier-every manwants. First, it is adequate means of life. But in the modern world that no more means to the workingman merely the means to exist than it does to anybody else. The standard of life is an elastic and changing thing, depending much upon the civilization of the time and place. Ideas of what is sufficient are fairly similar 
among men of similar occupation and surroundings. The least that is asked by any group, so far at least as it makes itself heard, is the means to rear a family according to modern ideas of the essential comforts and decencies, with a margin for education, recreation and saving.

It is not a matter to put into set terms by tables of the cost of an agreed list of necessities. Many serious attempts have been made in this way to arrive at a "proper wage" by schedules of average living expenses. But the workingman insists that such a basis is to be considered, not as a measure of reasonable desires but as the least a man can receive without actual degradation of life. His view of it can be understood at least by the farmer who hears the complaint that prices of his products are too high when, in good times, he is able to add some unaccustomed comforts to his scale of living.

It has taken us some time to become reconciled to the idea of workingmen receiving $\$ 4$ and $\$ 5$ a day. Twenty years ago it took us quite as long to accept the thought of $\$ 3$ a day, and somewhat earlier we were disturbed for the future when dollar-a-day mill hands began to earn a dollar and a half and worked ten hours instead of twelve or fourteen. A salary of perhaps $\$ 3,500$ to the manager who directed these men set him on a peak of distinction in his community hardly equaled by his $\$ 10,000$ successor to-day, and a man was wealthy with $\$ 50,000$ who is merely well-to-do at present with half a million.

But it is safe to say that neither the $\$ 10,000$ manager nor the half-million capitalist who is alarmed at $\$ 5$ 
a day labor regards the change in the status of his own group as in any way remarkable. We need not be surprised that workingmen do not take seriously, nor always kindly, the labor views of the man who expects other men to bring up and educate families according to American standards of decency, behavior, intelligence and good citizenship on half the amount for an entire year that he spends without a thought on a new automobile or a summer vacation. They may not dispute his right to the automobile-in fact, much of the bitterness against men of means, as such, is more apparent in radical literature than it is among actual wage-earners-but there is keen resentment of the disposition to condemn other men's efforts to realize a standard of life which is meager at best, in contrast.

\section{HUMAN BEINGS OR "CLASS PROBLEM"?}

There would be less of that disposition, and less of the ill will it breeds, if it were not so difficult for many people to think of the workingman as first of all a human being, an individual. Just so soon as we make a "class problem" of him we unconsciously think of him as a being in a different world, and when his special demands and ambitions are up for argument we bridle against them. Workingmen are twice as well off as they were in the old days, we say; they ought to be contented with what they have. To a great extent, apparently, we flatter ourselves that what they have gained thus far was freely bestowed, that the credit is somehow ours. They were obliged, in fact, to make the same 
struggle for it that arouses our indignation when they attempt, now, to take another step forward. Neither the employer nor the community, upon the whole, has yielded up to labor anything of material value any more willingly in earlier days than we are disposed to today.

If the workingman resents the attitude so commonly taken towards him and towards his efforts it is because there are some things, among his wants, which lie deeper than matters of wages and working conditions. $\mathrm{He}$ has been trained too long in the ideas of equality, at least of rights and opportunities, of human consideration and just treatment, not to sense it when he does not find them in the actual relations of man to man. Even with the man at the bottom of the industrial scale, unlettered and unskilled, it is the things which he feels but cannot put into words, much less into constructive ideas, that turn his mind and his hand either against the community or for it. To be legally free means much, but there is little to remind the man of it, day. by day, who still sees next above only the face of the arbitrary and all-powerful overlord. The right to a voice in determining the conditions of a man's own life and labor lies at the heart of the democratic idea. It is at the heart also of the labor movement. It means the right to have a larger outlook and to work towards it in one's own way, in common with one's fellows of like aim.

"In one's own way" is a chief bone of contention. It cannot of course mean in ways that deny the equal right of others. But it is a common habit of many, 
well-meaning people to set forth programs and methods such as they believe workingmen ought to want as being what they actually do want. There are those who insist that "what labor wants" is revolution, and there are others who offer solutions which have a much larger support among employers, or among social workers, writers or politicians than among the wage-earners for whom they are planned.

\section{THE STANDARDS IABOR DEMANDS}

Suppose we take the labor movement itself as authority upon what the largest audible group of workingmen actually want, rather than the employer or the doctrinaire. What unorganized workingmen want we have no definite means of knowing, but it seems not unreasonable to infer that if their voice could be heard it would be found much the same, in the main human requirements at least, as that of other workmen who have united to realize those requirements in larger measure.

At present, in this country, the most representative expression of authorized labor opinion in a large way is that of the 36,000 trade unions, approximately, associated in the American Federation of Labor. In these unions are now some four million industrial wage-earners, and in the railroad brotherhoods nearly a half million more of like aims and very similar methods. The program of the socialist movement we have stated, ${ }^{1}$ but its enrolled following is too small, thus far at least,

${ }^{1}$ See page 60. 
to be taken as the voice of a representative workingclass movement.

Many conventions of the American Federation of Labor, many declarations of its authorized spokesmen, have proclaimed "what labor wants" during the last forty years. There has been disagreement within the movement on some of these demands; many have related to special issues and conditions of the moment, but the central proposals upon which there has been general accord are these:

Wages adequate to a rising standard of living.

A working day of not more than eight hours.

The right to organize, to bargain on employment conditions through representatives of labor's own choosing. ${ }^{1}$

'Abolition of child labor, better provision for education, protection of working women, equal wages for men and women in the same employments.

No court injunctions in industrial disputes.

Popular election of judges. The initiative and referendum.

Safe and sanitary work-places, protected machinery.

Prompt and adequate compensation for accidents during employment, the cost to be borne by the industry.

Voluntary methods of insurance for sickness and unemployment.

Scientific program for reducing unemployment.

Restricted and better selected immigration.

Freedom of speech and of the press, with due responsibility for consequences.

International measures to prevent war.

${ }^{1}$ See page 140. 
An employment relation and a legal status which counts the worker as a human being and not as a commodity.

An effective voice for the workingman in the shaping of the industrial and political conditions under which he lives.

\section{LABOR'S RECONSTRUCTION PROGRAM}

The Reconstruction Program adopted by the American Federation convention in 1919 may be taken as the most comprehensive statement thus far put forth of what labor wants, at the present stage of industrial progress in this country. It is more conservative in tone than the program of the British Labor Party, but the outlook is broad and some of the demands far-reaching. The proposals this manifesto offers, summarized, are these:

That the principles of democracy should regulate the relationship of men in all their activities.

"That the workers should have a voice in determining the laws within industry and commerce which affect them, equivalent to the voice which they have as citizens in determining the legislative enactments which shall govern them," and, to this end, "that the workers everywhere should insist upon their right to organize into trade unions."

That "just wages will create a market at home which will far surpass any market that may exist elsewhere and will lessen unemployment." 
A living wage for skilled and unskilled, "which will enable the worker and his family to live in health and comfort, provide a competence for illness and old age, and afford to all the opportunity of cultivating the best that is within mankind."

A working day of not more than eight hours "except under the most extraordinary emergencies."

Equal pay for men and women for equal work, and no tasks for women which will impair their physical strength.

"An immediate end to the exploitation of children under 16 years of age."

Further development of coöperative buying and selling, with the active support of trade unionists, both to reduce unnecessary costs and to "prepare the mass of the people to participate more effectively in the solution of the industrial, commercial, social and political problems which continually arise."

Freedom of speech, of the press, of assembly and of association.

"To attain the greatest possible development of civilization, it is essential among other things that the people should never delegate to others those activities and responsibilities which they are capable of assuming for themselves. Democracy can function best with the least interference by the state compatible with due protection to the rights of all citizens."

The right of congress and of legislatures to reënact and make effective any law which a court has annulled as unconstitutional.

Continuation of labor's non-partizan political policy, 
through which during the past generation "the workers of America have secured a much larger measure of fundamental legislation, establishing their rights, safeguarding their interests, protecting their welfare and opening the doors of opportunity than have been secured by the workers of any other country. The vital legislation now required can be more readily secured through education of the public mind and the appeal to its conscience, supplemented by energetic, independent political activity on the part of trade unionists, than by any other method. . . . The rules and regulations of trade unionism should not be extended so that the action of a majority could force a minority to vote for or give financial support to any political candidate or party to whom they are opposed."

Ownership, operation or regulation by the government of public and semi-public utilities "in the interest of the public."

Development of public waterways, encouragement of the merchant marine, with full protection to the rights and welfare of seamen; ownership and operation by Federal and State governments of "all water power over which they have jurisdiction. The power thus generated should be supplied to all citizens at rates based upon cost."

Graduated taxation of idle lands suitable for use; legislation to enable tenant farmers and others to purchase land upon favorable terms and at low interest.

Irrigation and reclamation projects; government experiment stations. 
Federal licensing and strict public control of corporations.

More adequate workmen's compensation laws, with State management of employers' liability insurance.

Immigration restricted to "the nation's ability to assimilate and Americanize the foreigners coming to our shores," and entire exclusion during times of abnormal unemployment. Prohibition of all immigration for at least two years after the declaration of peace.

"A progressive increase in taxes upon incomes, inheritance, and upon land values of such a nature as to render it unprofitable to hold land without putting it to use, to afford a transition to greater economic equality and to supply means of liquidating the national indebtedness growing out of the war."

Greater opportunities for advanced education, and for industrial education with representation for the workers on all boards "having control over vocational studies or training." The right of teachers to organize.

Trade-union and employer supervision of the conduct of public employment agencies.

Housing projects carried on by States and cities, and credit systems to assist workingmen to build their own homes.

A "voluntary citizen soldiery," organized and controlled upon democratic principles so that it may never be used to jeopardize the liberties of the people. Unalterable opposition to "militarism" and a large standing army.

Government help to returning soldiers and sailors in finding work under fair conditions, their pay to be 
continued in the meanwhile, but not more than one year: opportunities, also, for easy access to the land, with capital supplied for its development.

\section{IS AMERICAN LABOR WITHOUT IDEALS?}

Such a program reflects of course more conservative ideas than those of most European labor bodies. For this reason, the American labor movement is often criticized as a commercial aggregation of wage-workers, without vision or ideals beyond the needs of the hour. Such an impression probably is due to the intensely practical character of the efforts of organized workingmen in this country, since their earlier and futile ventures in political utopianism.

But it is not possible to explain or understand a working-class struggle of the scope and achievements of the American labor movement as inspired by sordid motives merely. Running through all its manifestos, its literature, the philosophy of its best known leaders in thought or deed, from the days of Ira Steward and George E. McNeill to John Mitchell and Samuel Gompers, there is a current of idealism, of forward looking to a better civilization, a democracy of human welfare rising out of the painful and halting effort of many generations of men to bring it, bit by bit, into being. Much of this underlying motive force has been lost to public comprehension in the incessant, day by day struggle of labor along a far extended line to realize some of its ideals for the men, women and children not alone of to-morrow but of to-day. It is not the com- 
plaint of employers, at any rate, that organized workingmen are too "business like"; rather, that they are too much under the sway of theories and sentiment.

In replying to a fear once expressed by Miss Jane Addams that the practical methods of trade unions endanger their idealism, Mr. Gompers suggested that after all the test of the ethical lies very largely in the practical deed. "To make contracts and stick to them, even when they limit or take away the right of striking out of sympathy, is not to sacrifice idealism. To consult actual conditions and the dictates of reasonable expediency before striking or making demands upon employers is not to abandon any ideal ever proposed by intelligent unionists. The idealism of the labor movement," he continued, lies in the fact that in striving for better conditions and more equitable treatment here and now it is "really battling for social and industrial progress."

Twenty years ago, in a convention of the American Federation, Mr. Gompers said:

That we are still far from the goal for which the human family have been for ages struggling is due to our own shortcomings. There is no reason why we should not realize the highest hopes of an ideal life, where man's worth shall be measured by his real utility to his fellows, where his generosity and sympathy, rather than his cupidity and rapacity, shall receive the encomiums and rewards of a nobler manhood.

In the closing months of the world war he saw the approach to that goal in this wise: 
American labor .... has not ignored reconstruction problems; it is false to say that it is untouched by the higher democratic idealism that is stirring the world today. It realizes deeply that the work we are doing to-day will be the basis of organization to-morrow. No reconstruction program can wholly separate itself from the life of to-day and the future, but it must be built upon the institutions of the present and in accord with practical principles that have enabled us to make progress from the past.

It should be remembered that the elements represented in the American Federation comprise strictly a wage-workers' movement. It is of, by and for the wage-workers, but it holds the belief nevertheless that to raise the level of life for millions of the less fortunate is not to burden the rest of the community but to lay broad foundations for the common prosperity and security. Its choice of methods to this end it bases upon its own experience, in contrast with the practical results of various revolutionary movements. Any one familiar with what goes on within the meetings of central labor bodies and at national conventions of labor is well aware that a significant new proposal from any source-British, Russian or American-has its ardent champions and expounders. If it is not adopted, it is not at any rate because the members are permitted to remain ignorant of its nature or of the arguments in its behalf. Local unions here and there frequently do endorse schemes much more radical than the larger bodies are willing to accept.

Programs of a revolutionary leaning, wholly or in 
part, are very common among the interwoven labor, socialist and political movements of Europe. In the view of many whose own views tend in the same direction, they are the mark of superior intelligence and progressiveness on the part of European wage-workers. To other observers they represent chiefly the views of intellectuals and social propagandists of ability and force, who have taken leadership of the labor movement. Whether or not such leadership is to the advantage of labor is a hotly disputed point, on both sides of the water.

The ideas of the intellectuals are by no means unheard or unknown to American workingmen, but the decision and direction of policies in the labor movement is limited to actual wage-earners. This position is based upon the danger of opening opportunities to politicians and visionaries of no industrial experience to exploit the wage-workers' movement for personal or propagandist ends, dividing its counsels and frittering away its united effort for objects attainable in dissension over the unattainable.

The reality of this danger is a bitter chapter in American labor history, but it has been felt in England as well. In their discussion of industrial democracy, Sidney and Beatrice Webb have pointed out in much detail "how dangerous it may become to the strength and authority of a trade union if any large section of the persons in the trade are driven out of its ranks, or deterred from joining, because they find their convictions outraged by part of its action. ${ }^{1}$

${ }^{1}$ History of Trade Unionism, p. 627. 
In the opinion of an American observer long active in the socialist movement and closely familiar with the labor and radical movements of Europe, "American labor is to-day more united than labor of any country of the world with the possible exception of Great Britain. And this unity has been won and held against stronger influences making for division than exist in any other nation, since America has been the battleground of all the theories as well as all the prejudices of the workers of all Europe. Yet we are better united. The reason? Labor tends to unite on all labor questions; labor tends to divide on all the non-labor questions that take up so much of the time and energy of the political parties of Europe. The word 'solidarity' is more widely used in Europe; actual solidarity is more advanced in the United States. . . . It is due to this good fortune of our history and not to an inborn superiority of American workers that the American labor movement is the only labor movement in the world today that is built consistently on a democratic foundation, has an exclusively democratic policy and goal, and has never departed from democratic policies." 1

\section{ONE STEP AT A TIME}

Whether the American labor movement's faith in reformist measures as the necessary means of social advance implies a narrow vision depends of course on the point of view. The difference between the American and European movements in this respect, quite prob1921.

${ }^{1}$ William English Walling, in American Federationist, Sept. 


\section{THE LABOR MOVEMENT AND THE FARMER}

ably, relates more to methods and programs than to ultimate ideals for humanity. The hardness of the struggle may have limited the outlook of the American movement too closely, sometimes, to the "next thing ahead," but it would not be a just or intelligent estimate to say that it has no idea where it is going.

In brief, the American movement as it sees matters to-day is not convinced that a radically new and experimental system can at any time be fitted successfully to the infinite variety of human conditions, or that the man of the moment is able to plan the industrial and political order which will seem just and equitable and efficient to the man of a century or a half century hence. It is content that the future framework of society be such as may suit the temper and needs and will of the humanity which is to live within it, enlightened by all the experience it shall have gathered on the way. Meanwhile it acts upon the theory that eternal vigilance is the price of progress no less than of liberty.

"Men are not necessarily free," as Mr. Gompers puts it, "because Declarations of Independence so declare. Men are not necessarily free because the Constitution guarantees freedom." At another time: "I want the stars in the heavens. My aspirations know no limit for my fellow men, but ... I am not going to give up voluntarily the labor movement with its achievements of to-day for the chimerical to-morrow. . . W We prefer to go on in this normal way of trying to make the conditions of life and labor better to-day than they were yesterday, and better to-morrow and to-morrow's tomorrow than each day that has gone before." 


\section{IX}

\section{THE PUBLIC SITTING IN JUDGMENT}

No one thus far has been able to draw the line, accepted by everybody as just and proper, between the public's rights and interests and those of each of the many groups of which that same public is made up. It is the oldest problem of government.

The labor group, as many people see it, is a chief trespasser against the public interest, but the same question arises in every direction. Western farmers are no more willing to accept the views of certain eastern newspapers and politicians on the agricultural policies which are and are not in the public interest than workingmen are willing to govern themselves by employer ideas of the general welfare. Business men, in turn, resent particularly any attempt of "the public" to regulate prices or to decide what is a fair profit.

In a condition of free industry and free markets the line gets itself drawn, after a fashion, with no particular theory on the subject. Any group overreaching too far or too long either loses so much of the public's patronage or stirs up so much hostile legislation that eventually its own prosperity, even its security, depends upon drawing back to some line at which private and public interest more nearly balance. Within this debatable ground the give-and-take, the testing-out, always 
is going on. It is not a perfect method, but it prevails no doubt because men never have been able to agree upon any fixed standard or rule by which, as citizens and consumers, to limit themselves as individuals and producers. For the public is of course only the sum total of all its groups; the same people counted together instead of separately.

\section{"PARAMOUNT" RIGHTS OF MAJORITIES}

By the old Jeffersonian doctrine, every individual should have free play up to the point where he oversteps the equal rights of others. By a popular modern doctrine, on the other hand, in all industrial relations "the rights of the public are paramount." Somewhere between the two, we are trying to work out a practical code that shall come as nearly as may be to justice.

It sounds on first statement like a rule upon which all could agree, that the rights of the public always are paramount. At once we find, however, that what we really mean by "the public" in such a statement isthe majority. But we do not of course mean that a majority may do whatever it pleases. There are those of course who do so believe; for instance, that it may and ought to confiscate all private property on the ground that the public right is "paramount." And there are others who believe that this paramount right justifies fine and imprisonment for wage-earners or farmers who combine to sell their labor or their products on better terms. Clearly the rule does not solve the problem. We are still obliged to decide what we mean, 
to draw lines and set bounds to the rights of the individual on the one hand and of majorities on the other.

To secure the rights of the individual was the whole struggle of the English people for some centuries after the granting of Magna Charta. The power of government passed in the meanwhile from kings to parliaments, but it was hardly less necessary to secure man-rights against majority oppression than against the autocrat. The great basic guaranties of our own system of government are those of the right to life, to liberty, to the safe holding of property, to a voice in the conduct of government itself.

A vital part of the duties of our courts, indeed, is to enforce these guaranties as against any "paramount" right of majorities to do what they will with the liberties of minorities. Very probably the labor bodies which just now are demanding that legislatures have the power to reënact laws declared unconstitutional by a court may not fully realize that, in clearing the way for legislation desired at the moment, the bars are thrown down at the same time to the hostile measures of some unfriendly political majority which, freed of all constitutional checks, might very possibly fix itself in power by a chain of legislation which only revolution could break.

\section{PUBLIC NECESSITY AND FORCED LABOR}

How far the public's needs or comfort entitle it to coerce those who furnish necessary supplies or services is a question not likely to be settled by argument. We may expect it to adjust itself by degrees as the whole 
method of reaching agreements in industry works out in some systematic way, upon a basis of mutual confidence-evidently a long process. Before we decide that compulsion is the only remedy, we can at least see what it means if we put ourselves in the other man's place.

To take an extreme case, often cited: does the farmer who believes that railroad men ought to be compelled to accept wages they object to, in order to run trains supplying a city with milk, believe also that dairymen ought to be compelled to produce and ship the milk at prices they object to? It is, indeed, no simple problem.

The question of public rights in a labor dispute has come up strongly, as a rule, only in the case of necessary industries or services, such as railroads or coal mining. The idea is urged, however, that every labor contest in some degree affects the public welfare and ought therefore to be settled by a government agency in the public interest.

What, then, has the public at stake in a labor dispute? First, the maintenance of law and order: on this there need be no argument. Second, the regular supply of necessaries. Third, the general advantage in a business way of having all industries go on without interruption.

The strike is an interruption. It may and often does occur with no violation of law and order, but simply as an interruption it may and sometimes does bring serious loss and distress to some part of the community. Probably it stands first among the causes of prejudice against the labor movement. 
Workingmen might acknowledge all that is to be said against the strike and still protest that a majority of the citizens in the community cannot justly, even to serve their own necessities, enforce upon other citizens labor which they would not consent to have imposed upon themselves. In this view, for instance, a majority may no more rightfully require a thousand men to dig soal, in the pay of a private employer, because they have already dug coal for a dozen years or a month or a day, than to commandeer any other thousand men and set them at the job. In other words, if it must have an industry or a service continue, it may as justly attempt to compel some men, as employers, to pay the wages necessary to obtain labor as to require other men to perform the labor upon terms dictated by either the employer or the community.

In soviet Russia, it is pointed out, the business and middle classes have had ample opportunity to know the meaning of work under duress upon fixed terms, for the public good as seen in this instance by a proletarian government. The results have exhibited to socialists of other countries very generally the futility of labor imposed upon any group by the will of another, however large. Masaryk, the socialist president of Czecho-Slovakia, tells his people: "Proletarians would in vain compel the bourgeois to work, if they themselves are unable to control the work."

In point of fact, no way has yet been found of enforcing continuous service, among free citizens, except under prison sentence or military draft. Even if the Constitution did not prohibit involuntary servitude, the 
fining or imprisoning of men who insist upon quitting work, jointly or singly, does not of course do the one thing the public wants done-keep the industry going. To prohibit a strike is not to make men work. Instead, it may very possibly intensify resentment and breed new perils for old.

\section{THE PUBLIC'S "LAST RESORTS"}

Such at least are the main lines of the labor argument in this matter. If all negotiations for voluntary settlement fail, if public opinion has no effect, if penalties for striking do not actually keep an industry going, the public has the last resort alternative of taking possession for the time being and operating it with volunteers or troops, as it might in a military crisis. In point of fact the extreme emergency, such as this, becomes a reality much less often than we expect. What happened in the threatened triple alliance strike in England, as in the "outlaw" railroad strikes in this country, suggests unforeseen resources of the community in its own protection. In transportation, for instance, the immense growth of motor-truck facilities for moving food and fuel, with the oncoming possibilities in air navigation, are object lessons which can hardly be lost upon either railroad managements or employees. The very attempts, indeed, to abolish strikes by remedies which might spread the disease rather than cure it signify an increasing pressure of sentiment which ought not to be without effect in the working out of other means of composing differences. 


\section{WHERE THE MORAL OBLIGATION LIES}

There is indeed, in every vitally necessary occupation, a moral obligation which is not sufficiently felt as yet by either workingmen or managers. To accept employment at all, in an industry or service upon which numbers of one's fellow men depend for the necessaries of life ought to carry with it a sobering sense of responsibility, a determination to exhaust every reasonable means, a willingness to endure more for the time being than men need be expected to endure in purely private occupations, before taking the final step and quitting work. But the same obligation rests, too, on the employer. It is one of the chronic oversights in the public judgment, embittering to workingmen, that the blame for whatever happens is so commonly laid to a selfish and anti-social attitude on their part, with little or no heed to an employer attitude which may have had quite as much to do with the break in good relations. They would perhaps respond more quickly, when warned to remember their duty to the community, if convinced that the employer were being made to feel the public eye equally upon him. The sense of moral obligation must be mutual. It is a product of moral forces. The product of compulsion is a sense of injustice, backed with resistance.

\section{VIOLENCE AND INJUNCTIONS}

Facts do not bear out the charge, less often heard than some years ago, that the labor movement encourages 
violence in strikes. Local unions of strong radical leanings sometimes do, but the counsel of national leaders and the literature of the movement steadily warn against it. It is no uncommon thing for strike committees to direct the members of a union to keep away from the vicinity of the plant affected. In many cases of strike rioting, investigation has shown the greater part of it to be the work of hoodlums drawn to a point of anticipated trouble. Lawlessness probably never won a contest for labor; it has lost many. So well known is this that employing concerns have been charged in various instances with promoting outbreaks in order to bring odium upon the strikers or to throw the matter into the courts by application for an injunction.

Because of its objection to injunctions, the labor movement comes in for severe public criticism. In much of the comment it seems to be taken for granted that what labor wants is free license to riot and destroy property. The actual objection is that legitimate efforts of labor may be and frequently are defeated by court orders against acts in themselves lawful but forbidden if done in concert, according to the views and at the discretion of the judge who both issues the writ and punishes its violation. Disorder and destruction of property, if these are feared, are for the police to prevent and the criminal courts to punish. These are the legal remedies provided for crime, and if they are not adequate they can be made so. Acts of violence are already forbidden by law. To forbid them also by injunction is to make possible the fining and imprisoning of men charged with crimes, without trial by jury, since 
the punishment is not for the act as a crime but as contempt of court. This view was supported recently by a New York judge who, in refusing to issue a desired injunction, took the position that the penal code is the most effective injunction against violence and that "there should not be imposed upon it [a court of equity] the performance of police duty."

The injunctions are sometimes very sweeping, and forbid persuasion of any kind, by voice or printed word, the holding of meetings, payment of strike benefits to members of a union, and use of the public streets near a plant where a strike is in progress. Frequently they are issued when little or no disorder is in evidence, but upon complaint of an employer that his business is being injured or may be injured by a strike of his workmen or by efforts to organize them.

To this the emphatic protest is made that an injury to business by reason of refusing to work for an employer or persuading other men not to work for him no more justifies the outlawing of an effort to secure better terms of employment by these means than the taking away of a merchant's customers justifies legal restraint upon his competitors who are, undoubtedly, injuring his business. There is, it is contended, no more property right in the labor of another man than in his patronage.

The subject is much too involved for discussion here, beyond an attempt to state fairly the labor position in the matter, frequently misunderstood. The belief that many equity courts have carried the injunction power much beyond its original scope and intent is by no means 
confined to workingmen. It was shared by President Roosevelt, and is the view of many judges, both in State and Federal courts. There have been dissenting minority opinions in the United States Supreme Court in most of its important decisions involving this question. Labor injunctions of the character familiar in this country are not issued in England, under the Trades Disputes Act, and it was the intent of the Clayton antitrust law of 1914 to limit their operation here. However, there is apparently little change thus far in their scope and practical effect. They have been issued in restraint of farmers' organizations also, in a number of instances, but dismissed upon further hearings.

\section{THE IABOR VIEW OF STRIKES}

There is no love for the strike as such among workingmen, except in revolutionary organizations which welcome every outbreak as a blow at capitalism. Wageearners have reason to know better than any one else the losses and privations of long idleness. They are aware that the public suffers severely in some strikes, and they cite many evidences of prolonged effort to compromise, of strike orders withdrawn and issues postponed or waived in deference to public opinion. They protest that the chief end of a trade union is not to foment strikes but to gain some real and substantial benefit for wage-earners, and that the only actual power workingmen possess to that end, in the bargain with employers, is the reserve or last resort power of quitting work in a body. 
It is a negative step, taken in the hope or belief that the employer, rather than bear the loss of an idle plant or the cost of finding and training new men, will concede at least in part what is asked. It is not "class war," in the sense understood by revolutionaries, since the object is neither to capture nor destroy the industry but to regain employment in it upon better terms. The immediate cost may be heavy, in lost production and wages, but, so labor contends, a higher level of welfare once established is a permanent gain for the years to come.

In point of fact, it is a small proportion of industry as a whole that is involved in strikes at any given time. With the help of press headlines, we have grown into the habit of thinking of all modern industry as a battleground: normally, ninety per cent. of it is at peace. If it were not so, we should be in a continuous business and financial panic. Agreements are found upon innumerable grievances and demands in the daily run of the nation's industry, for every one that ends in open contest. But so long as free men unite to produce wealth, be the method private industry or socialism or communism, there is the possibility that not all will agree without dispute on what is a just division. The strike, for the time being, is an incident of these differences in industry, as is the lawsuit an incident of commercial disagreements, and the partizan compaign a phase of political differences under democratic government. Our civilization has yet to outgrow many things that are a standing reproach, the strike among them, but we are not to assume that it will not or cannot do so. 


\section{UNION SHOP AND "OPEN SHOP"}

Much the same may be said of the so-called "closed shop" or "union shop" question. It is a product of industrial conditions which are here, but not necessarily here to stay. Trade unionists do not, as is commonly supposed, always and everywhere demand employment of union members only. A bona fide "open shop," with no discrimination, the union men dealt with collectively as they prefer and the non-union men individually, does exist in some instances, although it is not ordinarily an easy thing to manage.

As a rule, labor spokesmen point out, the "open shop" employer is unfriendly to unions, and will neither recognize nor deal with one, even if he permits employees to join it. In such case the ignored union, unless it resorts to a strike, gets no attention for its requests and is unable to gain any benefits for its members. For all practical purposes the shop is non-union. On the other hand, where employer and union attempt to work under a contract, it is found that the presence in the shop of men who refuse to join with their fellow workmen to maintain what they have gained, perhaps after long effort, commonly means friction and ill feeling. It enables the employer, also, if so disposed, to increase the non-union proportion of men in the shop until the organization is destroyed.

It is for these reasons mainly that union men so generally object to working with non-members. That objection may prevent the non-unionist from getting a job in a particular shop, when the employer does not 
care to lose his union help in order to hire that man. On the other hand, it is pointed out, to insist that the union men are under obligation to remain is to say that one man's right to work for whom he pleases is greater than another man's right to work only with whom he pleases.

In any event, from this viewpoint, a labor contract limited to a certain group of men is not different in principle from commercial contracts for the entire output of a factory, or for the sale of goods of a certain make or brand, and of no other. A manufacturer or wholesaler cannot sell "to whom he pleases" if his intended customer has decided, for reasons of his own, to buy only of some one else. In a Minnesota case it was held by the court that: "It is a part of every man's civil rights that he is left at liberty to refuse business relations with any person whomsoever, whether the refusal rests upon reason or is the result of whim, caprice, prejudice or malice. With his reasons, neither the public nor third persons have any legal concern."

The whole argument is part and parcel of the always unsettled problem of private rights in relation to public rights. It would be more important if it had to do with a permanent or fixed condition, but the forces in human character which alone work out abiding relations of democratic coöperation lie far deeper. For that matter, even now the number of strikes based on a "union shop" demand is a small proportion of the whole. The great majority are upon issues of wages and hours.

Labor advocates insist that the "open shop" drive, much in evidence during the after-war period of de- 
pression and unemployment, has been for the purpose of breaking up or so weakening the unions that no resistance can be made to heary wage reductions or to working conditions dictated by the employer. They are not alone in this view. An investigation of present conditions in industry, by the New Jersey Chamber of Commerce, leads that association of business men to say:

'A movement is now on foot which, misusing the name of "open shop" and "American plan," is smashing labor organizations throughout the country by locking the unions out and forcibly deunionizing the workmen. ... It is undermining the confidence of labor in employers and ruining the foundations for coöperation between them. Similar campaigns in former periods of depression have only resulted in redoubled growth of unionism and the adoption by it of more extreme measures in the periods of prosperity which followed, and there is no reason to believe that the results of this campaign will be different. Campaigns of this nature are playing into the hands of the revolutionary element. Thus the cycle continues, with the participants in continuous and senseless warfare.

Two years earlier the Boston Chamber of Commerce, perhaps foreseeing such a situation, declined to approve an industrial platform proposed by the United States Chamber of Commerce upon the ground in part that:

The principles favored by the committees are in the main antagonistic to organized labor and are bound to be so regarded by labor men generally. ... . It would be unfortunate, to say the least, if the National Chamber were 
deliberately to take a position that would be reasonably sure to endanger its future possible and probable usefulness in the solution of labor problems, of which there are many yet to come.

On the other hand, there are many employers who make less of the union-shop idea in itself than of the vexation and waste of arbitrary shop rules and petty impositions which have frequently grown up under rigid labor contracts. Limitation of output, limitation of apprentices, "jurisdiction" disputes between unions claiming the same work, opposition to improved machinery-each has counted heavily against labor, both in dealings with employers and in the public judgment. Each has a history which throws light upon at least the original "reasons why."

\section{JURISDICTION DISPUTES}

The jurisdiction question, for instance, is by no means an invention of modern trade unions. The objection of workmen to having jobs they look upon as part of their own trade taken by other workmen is very ancient, and very human, however exasperating in many a modern instance. Evidence of it is as old at least as the early craft guilds, which were devised, according to a fifteenth century authority, "that everybody by them should earn his daily bread, and nobody shall interfere with the craft of another." 1 No one problem brings

${ }^{2}$ History of Trade Unionism (Webb), p. 20. 
more trouble to national trade-union officials than the task of arbitrating these disputes, and there is no argument between these men and employers as to the harm they do both to the labor movement and the industries affected. Outside the building trades, however, they are comparatively rare.

\section{APPRENTICES AND MACHINERY}

The limitation of apprentices, another ancient practice dating back to the English guilds, has back of it in our time the habit credited to many employers of training a succession of boys, not in a knowledge of the trade, but in specialized machine-tending jobs, displacing adult workmen, and at wages of beginners without families to support. There are signs, however, that the issue on this point has been growing somewhat less acute with the widespread attention now given to industrial and vocational training, through the coöperation of progressive employers, labor bodies and boards of education.

Opposition to improved machines and methods is virtually a thing of the past. In the early days of the factory system workingmen saw only the first effect of a labor-saving device, in throwing men out of work. How the new machines actually created employment instead of reducing it, in the tremendous growth of industry itself, became clear as time went on, and the labor movement's view of the matter has entirely changed. Whatever opposition crops up now, in special cases, is centered on the "speed-up" or "stop-watch" 
features of certain efficiency systems, or attempts to require more in effort or skill, of the operators of new machines, with very little sharing of the added product. But the later drift of labor ideas on efficiency has been apparent in recent conferences of industrial engineers with national labor officials and in labor resolutions, expressing, as Mr. Gompers told the convention of mechanical engineers in 1920, "appreciation of the value of the technicians of industry and the desirability of the labor movement's availing itself of scientific aid in all possible ways."

\section{LIMITING THE OUTPUT}

Where workingmen have attempted to slow down the pace, or put a fixed limit to the amount they would produce in a day or for a given pay, and where they have specified in working agreements how many apprentices should be trained in a shop in proportion to the adult journeymen, the object is commonly interpreted as monopoly - to keep all the work to be done strictly within the hands of the group already holding the jobs. Without a doubt there has been this motive in the minds of many union men, just as the monopoly or "cornering" idea has captured the imagination of many a business promoter and financier, operating in larger fields but seldom with lasting success.

But the idea of limiting output arose in the main from a different cause. It was intended as a check on the taskmaster or driving type of employer, working his men at an overtaxing pace or attempting to make 
the speed and skill of the best workmen in a shop the test or standard by which all were to be paid. The system of grading pay according to capacity, under piece-work, has much in its favor when honestly applied. The labor objection has grown out of the tendency, very common in earlier days at least and not unknown to-day, to fix the piece-rates at a point such that only the fastest, strongest or most experienced men can earn a fair living wage.

An interesting comment not without point in this connection was made at the convention of the American Society of Mechanical Engineers, in December, 1921, by its former president, Fred J. Miller:

Too many there are who would blame inefficiency entirely upon the employee. Production has been and is restricted by workers, organized and unorganized, and most of such restriction is wrong, economically, if not ethically. In most industries, however, I think it can easily be shown that restriction of production by workers is insignificant compared with the restrictions caused by financial juggling; by avoidable irregular employment of labor and of plant; by unnecessarily large inventories; by inadequate control of the movement of material through the works; by inadequate or entire absence of provision for teaching or training; and by absence of effective means of recording attainments of workers.

There is support for this point of view, from one quarter at least, in the testimony offered by two of the largest contracting companies in the country, during the New York building trades investigation of 1920-21, 
that by the records of important construction works their union workmen were found from twenty-five to thirty per cent. more efficient than the non-union. Whether this is a common experience or the exception, it may at least indicate that the restrictive policies credited to certain trades in particular are not always practised by the rank and file, when relations with employers are on a basis of fair dealing and good will.

\section{CONSPIRACIES AND GRAFT}

Nerertheless, the building trades in New York and other large centers have been for years the breeding places of the worst abuses to be found in employment relations in this country, yet having nothing to do with any vital principle of the working-class movement. At first a domination of bosses over workmen, then of unions over bosses, they became a joint imposition of contractors and unions upon the public. Since the recent overhauling of this situation by a legislative committee and through efforts of the American Federation of Labor, there is an end in sight of many of the practices which had, in moral effect at least, harmed the labor cause even more than the prosperity of the building industry. The labor movement of the State gave formal pledge that certain of the working rules and customs chiefly complained of would be discontinued, and a similar agreement has since been reached, through the Attorney General of the United States, with the national organization of bricklayers, masons and plasterers, whereby workmen are neither to restrict 
output nor refuse to handle material from any source.

Labor "graft," as it emerged in the New York situation, holds a large place in the public judgment of trade unionism. It is cited quite commonly as the prevailing state of affairs among labor organizations generally. If such were the case in fact, it is quite probable that the whole scheme of modern industry would have broken down long ago, for some employing interest is necessarily a party to every corrupt labor deal. In a more temperate view, instances of graft and abuse of power on the part of certain labor bosses and unions do not convict the entire labor movement of crime, nor are illegal combinations, profiteering, "fake" stock promotions and high financing to be taken as typical of the general character of American business life, and therefore as just ground for doing away with private enterprise altogether. The labor movement does protest that a public opinion sincerely desiring to do justice would demand equal punishment for both offenders in a fraudulent conspiracy, rather than regard jail sentences for the labor grafters and fines for the bribing contractors quite so much as a matter of course.

\section{THE WALKING DELEGATE}

The "walking delegate" is another object of dislike and prejudice, justified in many an instance, as it is against the shyster lawyer and the "ambulance chaser" familiar to every insurance company. Not even employers are of one mind, however, in looking upon the chronic trouble maker as a fair sample of the union 
business agent. Such an official became a necessity in the early days of labor organization, and the employers of the time had themselves mainly to thank for him, because of the common practice of discharging or making "marked men" of individual employees who ventured to appear with grievances or wage demands on behalf of their fellows. In modern large-scale industry, a paid business representative is as essential to a permanent association of workingmen, undertaking contracts with employers, as is the paid manager to the stockholders of a corporation. Frequently, employers in large industries have found the counsel of national officers of a union more conservative than that of local leaders, even among the employees, for it is seldom that a large labor body cares to expend its funds in a local contest unless the grievance is a real one and imperils some larger issue.

Occasionally the business agent is the bully and autocrat of newspaper cartoons. On the other hand, to any one familiar with the trade-union world as it is he seldom figures as a potentate to be envied. Held responsible by his organization for results, by employers for the good faith of the men he bargains for, paid little if any more, as a rule, than the workmen of his craft, he is constantly open to the criticism and suspicion of the dissatisfied within the ranks.

The "agitator" in some field is of course as old as human progress. Whether he is a menace, or merely a temporary nuisance, or a leader whose efforts in the long run leave matters better than he found them, depends first of all upon what he is agitating for. The 
labor movement asks us not to confuse the class-war agitator who attempts to destroy the industrial and political structure with the agitator who wants to get out of it for the wage-earners a larger share of the civilization they help create. "People talk about agitators," said Sir Charles Napier; "but the only real agitator is injustice, and the only way is to correct the injustice and withdraw the agitation."

\section{BOYCOTTS, PICKETS, BLACKLISTS}

Boycotting and picketing, in the public eye, are seen usually as purely malicious measures. Neither method has anything to commend it, in itself, nor has any war measure, other than as a choice of evils. It is difficult of course for most people, not themselves wage-earners, to appreciate the odds to be overcome in a contest with capital on a labor issue.

Picketing is an attempt by men on strike to persuade other workers not to defeat the effort by taking their places. Boycotting is a refusal to buy the products of a concern which will not grant what labor considers fair working conditions, and usually also to persuade others to a like course. Both have been abused to the point of intimidation. Both, carried on by legitimate argument, have been held within the law and on a plane with the common right to withhold business patronage or social favor, or to bid a man away from one employment to another.

The "blacklist," and the "individual contract" which requires employees to pledge themselves not to join a 
labor organization, are in practical effect of course employer boycotts of union workingmen. It will be recalled in this connection that officials of some of the largest steel producing interests, testifying in the building trades investigation in New York, in December, 1920, acknowledged refusing to sell steel to be erected by union workmen. Such a policy, whatever its justification as the companies see it, enforces both the boycott and the shop closed to union workmen.

The boycott under one name or another, or none at all, has been a common remedy for many offenses not reached by law since long before the Boston Tea Party. We have lately come through a wave of "consumers" strikes" and attempts to pledge people not to buy of concerns holding commodities at high prices. The various temperance societies, on strictly ethical grounds, carried on organized boycotts of brewers, distillers and saloon keepers for many years before these enterprises became unlawful, and not for the purpose merely of obtaining some concession or change in methods but with avowed intent to destroy their "business." The ostracizing of profiteers and trust promoters, rather curiously, has been urged by some of the severest critics of labor policies and of the labor boycott in particular. The Consumers' League "white list" of stores which handle no sweatshop goods may be termed in effect a negative boycott of stores which do.

The union label is based upon the same idea. By means of it, union members are asked to buy the products of union workmen, as all good Methodists are counseled to buy of one another, since the world takes 
care of its own! The label informs the public that the goods so marked were made in shops where the wages, hours, sanitary and other conditions, are such as have been agreed to by the organized workers of the trade.

\section{THE NEED OF FAIR JUDGMENT}

It is not of course with the idea of minimizing any abuse, much less the folly and waste of war measures in industry, that this background is pointed out, of the reasons for much that goes on before our eyes. But there can be no restoring of the mutual confidence and good will which alone rid us of abuses and strife until we at least attempt to understand, before passing judgment, the conditions in which the other man lives and works and has his being. So long as employers bribe labor leaders and plant spies in organizations they do not recognize in open conference, labor will distrust motives and seek to protect itself in rigid contracts. So long as workingmen allow the policies and conduct of their unions to fall into the hands of men whose idea of leadership is to "hold up" employers for all that power can extort, with no thought of efficient cooperation, there will be efforts to dislodge unions and evade the terms of agreements.

But the outlook is far from hopeless. These are not the practices and habits of most employers nor of most workingmen, organized or unorganized. We are in the midst of an industrial era which has come upon us in all its immensity, faster than our power of moral control. As yet it has only in part the knowledge and 
the will to settle its internal differences temperately, by the rule of reason. That it does know and care in part, however, gives us reasonable ground to expect the strike, the picket and the boycott to disappear along with the lockout, the injunction and the blacklist.

Meanwhile the wisest men of both groups, who have seen all manner of hostile and penalizing methods tried, in law and out of the law, acknowledge that the need is not for more clubs to beat each other down but for limitation of arms, with a realizing sense of the necessity of respecting mutual rights and coöperating for mutual benefits. Neither officers nor crew can scuttle the ship and not go down with it. 


\section{$\mathrm{X}$}

\section{REMEDIES, OLD AND NEW}

IT is not a discouraging thing that more "solutions" of the labor question have been proposed and tried in the past generation than in all the history of industry. In science, the discoveries of lasting worth to humankind have come nearly always out of a thousand forgotten experiments, most of them failures, a few throwing light on the next step to take.

The discovery we have to make in industry, as we had to make it yesterday and shall have to make it to-morrow, is a way to provide for the rising standard of living and of democratic recognition which the millions who run the world's machinery, and cannot be spared, never cease to demand. If science and invention alone have not solved the problem, nor capitalist organization, nor trade unions, nor profit sharing, nor the efforts to reduce friction through mediation and arbitration, industrial courts and employee representation, are we to conclude that in none of these is there anything of value? More probably there is in each the germ of an idea which cannot be cast aside in the building up of a workable and result-getting code of relations. Some of them already have fitted into place; we take them for what they will do, well aware that they will not do it all.

Just what each of them is fully worth only further 
experience can make clear. We can only relate here, very briefly, what some of them are and what they have accomplished thus far.

\section{TRADE AGREEMENTS}

Trade Agreements have been in successful use in a large number of industries for a number of years. Some of the best known are in the printing trades, boot and shoe manufacture, iron molding, garment making, glass bottle blowing, the building trades, granite cutting, coal mining, and the steam and electric railway service. They take the form, usually, of a contract between a firm or corporation and a union of workingmen in some particular craft, or between an employers' association and a national organization of workmen. The wage scale, hours and other working conditions are named, and each party undertakes to hold its members to observance of the terms. Frequently it is provided that any disputes arising during the term of the contract shall be settled by arbitration, on some agreed plan.

It is urged against this method that it affords only a partial remedy, that it does nothing for trades that are not organized, that a man must join the union in order to get a job in an organized shop, ${ }^{1}$ that contractors and men sometimes virtually "corner" a trade or industry, agreeing to deal only with each other and making the public pay unreasonable costs. We have already discussed just such a situation, in the New York

${ }^{1}$ See page 124. 
building trades, and the reforms now being worked out.

On the other hand, it is pointed out that in modern industry it is no longer practicable for corporation managements to deal individually with thousands of workingmen; that the very conditions under which machinery is run and labor subdivided compel the fixing of wages and hours uniformly for given classes of work, as a rule, but that in the absence of agreement the fixing is done by the employer alone. The trade agreement, by a voluntary bargain, is shown in many instances to insure stable working relations for long periods, or until changing conditions would require changed terms anyway.

If it does not cover the whole industrial field, its advocates point out that the labor conditions assured by a trade agreement tend to become standard for a given locality and industry, so that its benefits are shared by many more workingmen than are actually covered by its terms. No one system, it is argued, can be fitted to every type of industry everywhere; what succeeds over a wide field need not be discarded because some other method succeeds also, under other conditions. Each has its value in the total experiment; each is open to abuse; none is beyond the reach of public opinion.

\section{COLLECTIVE BARGAINING}

Collective Bargaining, as the means to trade agreements of some sort, formal or informal, is a crucial point around which organized labor's battle for life has 
turned, for a hundred years. Public attention was centered on it as never before, during the President's Industrial Conference in October, 1919. The conference was called in the hope of promoting industrial peace through agreement on certain general principles. It was made up of prominent representatives of employer and labor interests and of spokesmen for the "public" not directly engaged in industrial disputes but affected in some measure by them. After many attempts to find a common ground the labor group proposed this:

The right of wage-earners to organize without discrimination, to bargain collectively, to be represented by representatives of their own choosing in negotiations and adjustments with employers in respect to wages, hours of labor and relations and conditions of employment, is recognized.

This was accepted by the group for the public, which in fact contained a number of employers. Several delegates in the employer group also agreed to the statement, but a majority rejected it. As a compromise, the public representatives offered this resolution, which the labor group accepted:

The right of wage-earners to organize in trade and labor unions, to bargain collectively, to be represented by representatives of their own choosing in negotiations and adjustments with employers in respect to wages, hours of labor and relations and conditions of employment, is 
recognized. This must not be understood as limiting the right of any wage-earner to refrain from joining any organization or to deal directly with his employer if he so chooses.

It will be noted that the "union shop" was not included, as an essential of collective bargaining, in either the proposal offered by or that accepted by the labor group. It was left as one of the matters to be settled in the bargain, according to circumstances. Nevertheless, a majority of the employer section again stood opposed, the objection coming from employers who decline to discuss any labor agreement except with actual employees.

In other words, the line of division remained where it always has been, except that there was evident a marked growth of public sentiment, shared by a considerable employer group, in support of the right of a wage-earners' organization to be heard through its own spokesman, as on a par with the right of stockholders of a corporation to transact business through an attorney or by a director who may have no other connection with the business. But it was impossible to bring the opposing views together on this point; the labor delegation withdrew and the conference ended.

Why workingmen lay stress upon collective bargaining is no longer a mystery to farmers, at any rate. It is to-day a matter of deep concern to the progressive agricultural movement, in another form of course, but with the same underlying idea. In April, 1921, the Secretary of Agriculture, Henry C. Wallace, said to 
the Farmers' Grain Marketing Committee of Seventeen, in Chicago:

The right of the laborer to form organizations for collective action and collective bargaining is clearly recognized. The right of manufacturers, merchants and other groups of business men to organize themselves into associations for the promotion of their mutual interests is not disputed. So also the right of farmers to form similar associations, both for the promotion of their general interests and for the sale of their labor in the form of crops, with a view to securing fair prices for their products through greater efficiency in handling and distributing them under free competitive conditions, must be admitted without question. A denial of this right would result in reducing the free farmers of the United States to a condition comparable with the downtrodden peasants or peons of less enlightened countries, and would bring upon us all the griefs which those countries are bearing.

\section{INCORPORATION OF UNIONS}

Incorporation of Trade Unions is advocated on the argument that they cannot otherwise be held responsible for their acts. The point has lost some of its force since the famous Danbury hatters' case, in which the union was sued for damages resulting from a boycott. The Supreme Court of the United States decided, in 1908, that individual members of a union are responsible, and fines were collected from as many as could be reached, the homes of many Danbury workmen being sold to pay the judgment. 


\section{THE LABOR MOVEMENT AND THE FARMER}

Trade unions have contended that they are not business corporations; carried on for profit, and ought properly to be classed with other types of voluntary associations which are not compelled to incorporate; that many. unions, especially among workingmen of small earnings, could not afford the legal expense of complying with the many technicalities of corporation law and would have to disband; that unions could be prosecuted for lawless acts committed by spies placed within the ranks for that purpose, and the funds tied up at critical moments in a labor struggle; that they might, in fact, be obliged to defend actions brought on all manner of pretexts but with the actual object of emptying their treasuries.

"I can well understand," said Stephen S. Gregory, a former president of the American Bar Association, with reference to incorporation of trade unions, "why they would object to doing that . . . for the same reason that the American Bar Association and most associations of lawyers which certainly ought to have, and no doubt do have, a very high degree of confidence in the courts, object to incorporating. . . The difficulty about incorporating, for instance, in the American Bar Association, is that they have 10,000 members. I do not think that there would be 10,000 lawsuits, if they were incorporated, but if they were incorporated they would be liable at any time to have some discontented member filing a bill and trying to have a receiver appointed and trying to regulate-this is an age of regulation-the association. . . . We have never done it-as I think, wisely. .. Probably a good many members of the 
labor unions feel the same way. I think they are wise about that." 1

Violation of agreements is freely charged on both sides. The unions insist that employing companies, although duly incorporated, very rarely can be reached in the courts for violation of a labor agreement, partly because of the unions' financial inability to fight long legal battles and partly because a contract may be constantly evaded in the intent without furnishing a positive case at law. Indeed, whenever either party breaks the letter of an agreement or fails to live up to an arbitrated decision it is almost always charged that the other already has violated it in the spirit.

In the recent clothing workers' strike in New York, the court sustained the claim of the union that the manufacturers had broken the contract, and ordered the shops reopened. On the other hand, during the great rise in living costs after the war many unions demanded immediate wage increases without waiting for existing contracts to expire. The truth of these matters, from both standpoints, is often difficult to obtain. It is significant that for many years, in a number of prominent industries and services, there have been few complaints of broken agreements on either side. Where they have occurred on the part of labor, the national organizations in notable instances have themselves filled the places of the strikers, or expelled the offending union.

The one certain guaranty of good faith, in labor 1914.

1 Testimony before Federal Commission on Industrial Relations, 
agreements as in any relation of life, was stated in blunt terms by the English labor leader James $H$. Thomas, in his remarks at the Denver convention of the American Federation of Labor in June, 1921:

You have no right to demand of an employer a standard of honor that you set up unless you are prepared to concede that same standard of honor to the other side. In other words, our movement has gone beyond the agitation stage; our movement is part of the life of the community, and we must stand four-square with honor and dignity and say: "We will treat with honest men, but we treat with them because we are honest men ourselves."

\section{PROFIT SHARING}

Profit Sharing is no new idea. Many hundreds of business enterprises practise it in some form, in this country and abroad, and hold varying opinions on its practical worth. It is of course far from satisfying that school of social theory which holds that the entire product of industry belongs to labor.

The basis on which profits are divided with labor varies widely, according to the ideas of the employers who adopt the plan. There is no common agreement on what is a just and scientific division. In theory it is supposed to bear some relation to the proportion capital and labor each create, of the total product, but we have no recognized rule for determining this. If labor's share were to be only what it can create barehanded, without machinery or management, it would 
hardly equal Chinese coolie wages. If capital's share were to be what machinery or management, as such, can create without labor, it would be nothing at all. The question just what each of the three should receive remains as difficult as Mr. Carnegie's question as to which leg of a three-legged stool is the most important!

What each actually does receive, in the give and take of industry, depends mainly upon its bargaining power; in the long run it must be enough at least that each will continue working with the others in preference to doing something else. In other words, the natural limit of what either labor or capital can take for itself is found at the point where the other loses interest and efficiency, or withdraws entirely, thereby lowering or destroying the productive capacity of the industry from which the share of each is drawn. It is a constantly changing division, and it has proved no more possible under profit sharing to agree upon any basis for a fixed permanent ratio to each than under the straight wages system.

One of the commonest profit-sharing plans is to set aside, first, the interest on capital and divide the remaining profits in the proportion of the invested capital of the company to a year's wages of the employees. The criticism is made upon this that as the earnings of labor are taken as the basis for labor's share the earnings (interest) of capital and not the total capital itself ought to be taken as the basis of the employer's share in the profit division. In any event, it is a basis fixed by the employer for dividing a surplus which may 
exist one year and vanish the next. For this reason the labor movement holds that to accept profit sharing in lieu of a fixed wage, jointly agreed upon and revised from time to time as conditions warrant, is to exchange substance for shadow. Particularly would this be so regarded if the idea were carried out logically and labor asked to share losses in poor years as well as profits in good years.

Whether or not profit sharing actually increases the earnings of labor always has been a disputed point. It does, of course, when the prevailing wages of the locality and industry are paid, with the profit share in addition. Where the wages are below standard, the employees may earn no more in regular pay and profits together than workingmen in other plants with a higher wage scale. Trade unionists maintain that this is very frequently the case. It is the fact at any rate that profit sharing is carried on in the main by employers who have no wage agreements with organized workingmen. Some profit-sharing employers find that workingmen increase their efforts in order that the profits to be divided may be large; others report that in years of small profits or none the men are disappointed and suspicious.

Profit sharing is far from acceptance as a complete remedy for the labor problem. It has not prevented strikes. Where it is genuine in spirit and method, however, and not a substitute for something of greater value to labor in earnings or in rights, it has helped to build up a sense of partnership and common interest, an achievement well worth while in itself. 


\section{SOCIAL INSURANCE}

Social Insurance, in the form of sickness and unemployment relief, old age pensions and death benefits, paid entirely out of taxes or jointly by the government, employers and workingmen, as in Germany, has had little popular support thus far in this country. It is not adrocated as a cure-all but as a way of providing for the human misfortune and disability which the ordinary workings of industry do not take care of. The amount of relief granted under the foreign systems is very small, and the cost of operating the funds relatively high, largely on account of the necessity of guarding constantly against impositions.

The great bulk of the burden of sickness and old age support in this country is carried privately, through insurance policies, savings bank accounts and family aid. A very large number of workingmen and their families are protected also under the benefit funds of trade unions and the insurance and pension funds of employing corporations. The latter idea has been extended recently to "group insurance" of employees against sickness and accidents from causes not connected with employment, but which cause them to lose working time, to the detriment both of themselves and of the business.

The weight of opinion in the labor movement in this country is in favor of voluntary but against compulsory insurance. The danger foreseen is that the appetite for state aid, growing by what it feeds upon, will lead in turn to a widening of government control over the 
lives and liberties of the beneficiaries. The subject is frequently up for debate in conventions of the American Federation of Labor, which endorsed a bill of limited scope drafted some years ago by William B. Wilson, then a member of Congress. In Great Britain, with reference especially to unemployment insurance, the trade-union movement has modified somewhat its earlier approval. The Trade Union Congress of 1921 declared that: "Our whole emphasis is placed upon the provision of work." In the opinion of the British Trade Union Review: "Unemployment insurance is no remedy for the problem of unemployment."

The seriousness of the problem to every wage-earner's family gives point to the labor demand for wages sufficient not only to the needs of to-day but for the uncertainties of to-morrow. Very many who could save for the "rainy day" of course do not do so, but it is pointed out that they may be still less likely to provide for the future if assured of automatic state aid in time of need. A proposal which finds favor in some quarters is that the cost of old age pensions could be met by a pro rata charge upon all employing industries and paid according to the number of years of a wage-earner's service, wherever (within the United States) or however employed.

\section{WELFARE WORK}

Welfare Work describes the effort of employers to go beyond the letter of the law or of trade agreements in making the conditions of labor safe and healthful 
and in providing various comforts and opportunities intended to humanize the employment relation. The "model factories" and model factory villages, now so common, are in striking contrast with the ugly, unsanitary firetraps and barracks which in early days of modern industry did much to convince workingmen that capital had no thought of them as human beings, and drove them to organize in bitterness of spirit.

Many corporations to-day, in addition to light and ventilation and cleanliness in the plant, provide hospital service, lunch and rest rooms and modern sanitary facilities. Some very large concerns go farther and maintain recreation fields, libraries and schools, banks for savings, sickness and pension funds, even churches, and build houses for rent or for purchase by workmen out of their wages.

If it were possible to remove all thought of paternalism from these humane undertakings, and if they were not so often carried on by employers unwilling to allow employees the liberty to organize, they would no doubt have had more influence in bringing employers and workingmen generally to a closer understanding. No doubt it is true that much money has been spent on welfare work in the belief that it is cheaper than granting the conditions unionized labor would demand; on the other hand, there are many concerns having agreements with labor which also "go the second mile" and interest themselves in the well-being of the workingmen in a genuine spirit of humanity and good citizenship. Welfare work does not offer itself as a final solution, but when it is not "handed down" to workingmen 
as a substitute for rights they consider fundamental it is a force for good will and marks a step ahead in the decencies of industrial civilization.

\section{REDUCTION OF UNEMPLOYMENT}

Employment Planning, on a scientific basis, it is generally agreed would relieve the labor problem of one of the chief causes of distress and unrest. Widespread study is given to the problem of how to distribute work, in the country's industries and public services, so that employment may be more regular and continuous. We have now in busy months or in "boom" years a shortage of help in many industries and localities, followed by idleness in slack seasons or "hard times." Many remedies have been offered and many tried.

Public employment offices have been set up quite generally through the country in the last twenty-five years. There are now nearly one hundred managed by the Federal government and about one hundred more by cities and States, besides others of a semi-public nature. The Federal employment offices, coöperating with the Department of Agriculture and the Post Office Department, interchange information on the state of employment in different parts of the country, for the benefit of men out of work. The labor movement strongly supports the idea of public employment offices, so safeguarded that they cannot be used for strikebreaking purposes. Trade unions themselves, in industrial depressions, have carried on a much more thor- 
ough-going work than is generally known for relief of their unemployed members and in helping them to find jobs.

By far the most comprehensive program put forth thus far to meet the problem on a national scale was framed by the President's Unemployment Conference in the fall of 1921. This body of business men, economists, employment specialists and spokesmen for labor, under the chairmanship of Secretary Hoover, agreed upon a series of emergency proposals which were widely taken up throughout the country. Among these were:

Immediate starting of all authorized public undertakings, such as street improvements, public buildings, water and sewerage systems and reclamation projects.

Expansion of the employment service of the United States Department of Labor.

Coöperation of governors, mayors, and citizens' committees in efforts to revive building construction through finding capital on fair terms and removal of freight discriminations, price combinations and restrictions of effort.

In manufactures: making up stock in advance of immediate demand; dividing work among a larger number of men on a part-time plan or by rotation of jobs; using slack time for plant repairs and new construction; partweek work and fewer hours per day; no profiteering, so that lower prices may encourage larger purchases and thereby reëmploy more labor to supply the increased demand.

Mayors of cities were urged to take the lead in organizing community effort to meet the emergency, with 
the aid of a publicity drive launched by the Conference. The systematic attack brought out additional means of employing men in emergency work, and with material relief in some of the severest phases of the crisis, according to testimony both from labor sources and public agencies. The Conference recommended a number of national policies as essential to full business recovery, and arranged for further study of permanent means of preventing unemployment, especially in the matter of equalizing seasonal work. The program as a whole was decried by the radical press but the tradeunion movement very generally united in furthering it.

\section{LABOR IEGISLATION}

Labor Legislation draws a line beyond which free competition may not go, in the use it makes of the human element in industry. Most of it has been enacted only after long effort and stubborn resistance: at almost every point public opinion gave only grudging consent to the measures it now so fully approves and would not see repealed. The achievements which stand out foremost are the laws prohibiting child labor, limiting the day's work and prohibiting night work for women and minors, making wages a prior claim, requiring safe and sanitary work-places, providing factory inspection, employment bureaus, arbitration boards and methods of compensation for accidents in industry.

Such legislation regulates and protects but it does not take industry out of the hands of private enterprise and operate it collectively. It is therefore not "social- 
ism" although often loosely so described. Through it the community decides what conditions in industry civilization will not permit and what are best left for workmen and the managers of capital to settle between themselves.

Labor legislation has worked a vast change in the conditions of life and work of those, especially, least able to hold their own, but it has its limits of usefulness. The labor movement itself is wary of too much government help where workingmen have found it possible to protect themselves without it; for instance, it has favored legal regulation of working hours for women and children but opposed it for men. For another instance, it has found that minimum wage laws often have the unforeseen effect that employers look upon the minimum wage, once fixed, as actually the maximum they ought to pay, and urge that employees ought not to expect more than a public commission has found to be a "living wage."

To the extent that wise labor legislation has removed some of the worst injustices and causes of discontent it has brought the human problem of industry into higher ground. With a long way yet to go, that much at least may be set down for gain.

\section{MEDIATION AND ARBITRATION}

Mediation, Conciliation and Arbitration are, of course, simply means to an end. They are not in themselves solutions of anything, either in industry or in the dealings of nations. That they are more rational, as 
means, than strikes or lockouts is hardly open to question. Until a state of human society is attained in which no differences ever arise we shall either discuss and agree or fight and compel. It is merely a choice of methods.

The first object of mediation is to bring the opposing parties into conference. Usually it is attempted by people whose business is injured, or, if the dispute affects the community, by a citizens' committee, mayor, or public board of conciliation. Within the last twenty years The National Civic Federation has attempted to extend the idea still farther by bringing to bear the mediation of men of large interests and national influence, both employers and labor leaders, in many instances with striking success.

When no direct settlement has come out of mediation efforts it has been agreed very often to leave the matter to arbitration. In the labor view, no principle of liberty is sacrificed in working under an adverse award where this method of settlement was voluntarily agreed upon in the first place. Nevertheless the results, often, are not entirely satisfactory. In the arbitrations provided for in trade agreements, the umpires quite commonly are men of some practical familiarity with the industry. In public arbitrations they are more often eminent citizens of excellent intentions but little understanding of the particular conditions. The decision in most such cases merely "splits the difference" between the claims of both sides; one or the other feels that his case was not competently judged and awaits an opportunity only to try issues again. 
COMPULSORY ARBITRATION

Compulsory Arbitration, intended to prevent strikes absolutely, has proved in practice even more likely than voluntary arbitration to end in evasion and refusal to abide by the award. The decision is forced upon one or the other party without its consent. When this plan was first adopted in New Zealand and Australia it was believed to be the ideal solution of the whole labor diffculty. It was begun in a period of business prosperity and most of the decisions for some years favored the labor claims. When conditions changed and wage reductions were ordered it was found increasingly diffcult to hold men to their jobs.

Rather than accept fines or prison terms they would disappear from a given industrial district, or even leave the country. Of the Australian experiment, Prime Minister Hughes said recently, in the Australian Federal Parliament: "Years have passed and this perfect piece of legislation has turned out to be, despite every kind of minister in office, the most inefficient and hopelessly futile effort to solve the industrial question that ever came out of the laboratory of any industrial workshop."

In the United States, most of the sentiment in favor of stricter public control of labor controversies is now centered on two other ideas, compulsory investigation and industrial courts.

\section{COMPULSORY INVESTIGATION}

Compulsory Investigation has been on trial in Canada since the passage of the Industrial Disputes Act in 
1907. This measure requires that in certain public services, and in mining, strikes may take place only after a public investigation of the matters at issue. The investigation is made by boards of three members, one named by the employers, one by the workers, and the third selected by these two, or, if they cannot agree, by the government.

The plan has had a mixed record of success and failure. When workingmen have declined to wait for the results of an investigation no way has been found to compel them to remain at work, nor has it been possible to enforce wage awards when employers refused to pay the rates fixed. The system has been effective when voluntarily accepted, as may be said of all labor adjustment methods, with or without government machinery. There have been many and serious strikes in Canada since 1907 as before. The Canadian Trades and Labor Congress, which at first endorsed the Act, has since demanded its repeal. The chief objection of labor to compulsory delay is that it allows the employer that much additional time in which to learn all the plans of the workingmen, arrange for strike breakers and virtually win the contest before it begins.

A modified plan of compulsory investigation was put forth by the second Conference on Industrial Relations, called by President Wilson late in 1919. Under this proposal strikes are not prohibited, even during the investigation. The country is divided into twelve industrial districts, each with a regional chairman, empowered to form an adjustment board to which both sides in a dispute may voluntarily, submit their differences. 
If either party refuses to do this, a regional board of inquiry may be formed, with power to examine witnesses and records and make public its report on the facts in the controversy. The idea is that, in most cases, if either party is taking an unjust and arbitrary attitude it will prefer to come to a reasonable agreement rather than stand out against public opinion.

When a matter has been submitted voluntarily to a regional adjustment board, under this proposed plan, if a unanimous decision is reached it has the same binding effect upon both parties as a trade agreement. If no such decision is reached, the disputed case goes to a national industrial tribunal of nine members, or to an umpire chosen by the parties, and the decision reached by this board or by the umpire also becomes in effect a trade agreement, binding upon both parties.

In a sense this is a compulsory feature, but only in the degree that the award of a voluntary arbitration is compulsory, subject to penalty for violation, since neither party is obliged to submit its case in the first place. The plan, therefore, has seemed to some a piece of machinery which might prove a standing invitation to submit issues, not because they could not be settled as readily through private means but because of the opportunity to magnify grievances through wide publicity and put the other party in a bad light for "refusing arbitration."

However, the report goes back of its own plan and points out the general principles it believes should govern in certain matters most commonly in dispute, such as wage and hour standards, housing, the labor of 
women and children and the right of workingmen to choose their own spokesmen in dealing with employers. Its proposal for shop committees meeting regularly with the managements is already in force in many establishments, with excellent results.

Very recently the regional idea has been accepted by the railroad executives and the brotherhoods of train service employees, at the instance of Secretary Hoover, to the extent at least of joint conferences on wages and working conditions in advance of submitting disputes to the Railroad Labor Board. The three regions for which these conferences are proposed include, respectively, the railroads of the eastern, southeastern and western districts. The hope is to adjust as many as possible of the labor problems of the railroads directly between the managers and men and relieve the overburdened Railroad Labor Board of all except matters on which no voluntary agreement can be reached.

\section{INDUSTRIAL COURTS}

The Industrial Court is another proposal for settling labor questions by a form of compulsion. It has been much debated since the Kansas Court of Industrial Relations was established, in January, 1920. Efforts are under way to set up similar tribunals in several other States. The plan, like compulsory arbitration, is based upon the theory already discussed in another connection, that the public interest always is paramount. ${ }^{1}$

Often described as a new idea, it is in fact as old ${ }^{1}$ See page 114. 
in principle as the wage-fixing powers of the English courts of quarter sessions, dating from the sixteenth century, but long since abandoned. The need of such a measure is urged on the ground that labor troubles affect the public more seriously than at any time in history. It is true of course that the gravest of possibilities are always before us, even though some of the most alarming strike threats never materialize but are settled before a final break. The peril is by no means a new one, however. It may be fairly questioned whether any modern labor contest has disturbed the life of the community to anything like the extent that medieval England was upset by the Peasants' Revolt of 1381 and the hundred years of wholesale refusals to work on the old basis, which finally broke down the feudal system.

The belief has been held through several centuries that the claims of workingmen ought to be taken in hand and settled by government authority, on the ground that public interests are menaced by the liberty (of wage-earners) to combine and quit work at will. English industrial history is full of counsel such as the Committee of the Privy Council of 1726 gave to the weavers who had combined to petition the king "against the harshness and fraud of their employers the clothiers." They were advised, "for the future,' not to attempt to help themselves by unlawful combinations, but always 'to lay their grievances in a regular way before His Majesty, who would be always ready to grant them relief suitable to the justice of their case." " 1

${ }^{1}$ History of Trade Unionism (Webb), p. 50. 
British trade unions were brought into court and very nearly stripped of power, for the time being, under the famous decision of 1901 against employees of the Taff Vale Railway, but the reaction of sentiment which followed led to a sweeping guarantee of the rights of labor organization, in the Trades Disputes Act of 1906. A plan for industrial courts with power to enforce awards was brought forward by the British Minister of Labor in 1919, but aroused widespread protest and was not carried through.

\section{KANSAS COURT OF INDUSTRIAI RELATIONS}

The Kansas court consists of three judges appointed (originally) by the Governor with the consent of the State senate. Its powers extend over all public utilities, transportation, coal mines and the manufacture of food and clothing. Unions are recognized, but combining to quit work in these industries is forbidden. Any violation of the Act or of any valid order of the court, or any attempt to persuade or compel a violation, is punishable by fine and imprisonment. If, nevertheless, an industry is tied up by a strike, the court may take it over and operate it. 'Any dispute in the industries named may be brought before the court on its own initiative or that of the attorney general of the State, or by complaint of either party or of any ten tax-paying citizens in the affected locality. The court may then investigate the case and fix the wages, hours, working rules and conditions, subject to an appeal to the Supreme Court. Any wage advance granted dates back 
to the first application to the court, or if a reduction is ordered the workingmen must refund the difference to the employer for the same period. The value of the latter provision apparently depends upon whether the men remain within reach and still have the money.

It is stated by Governor Henry J. Allen, the sponsor for the plan, that of thirty-four decisions rendered by the court in its first two years all but one have been accepted and obeyed. On the other hand, it has obviously not prevented strikes of a serious nature and in vital industries, in Kansas. The problem of keeping men at work who refuse to remain in a given employment, under an award, remains unanswered, and seems unlikely to be solved by the recent attempt to arrest striking miners and set them to work under vagrancy ordinances. Labor critics of the plan insist that the compulsory feature has added a new element of bitterness to the industrial situation, stimulated radical sentiment and lessened the power of the national organizations to hold it in check.

It is not charged that the Kansas decisions thus far have shown prejudice against labor. Most of them, on the contrary, have granted wage advances, which may throw light upon the fact that local unions have accepted particular decisions while the labor movement in general opposes the court on principle. It is contended that the real test will come, as it did in New Zealand, when the decisions begin to run against labor.

In other words, the same government body which has the power to raise the level of working conditions for thousands of wage-earners to-day has also the power to 
lower it to-morrow, perhaps by the opinion or will of one man, the third judge. It is pointed out that, by this means, the settlement of the terms upon which some men are willing to work for other men is taken out of their hands and carried over into the field of politics, and can never be wholly free of the pressure of political influence.

For instance, in the labor view, the political powers behind such a court in a State largely agricultural are likely in the long run to heed a popular opinion not over-friendly to the ideas of industrial labor. In States of large wage-earning populations the case is reversed, and the threat of political defeat would hang over the head of an administration responsible for judges whose decisions ran mainly against labor: in either case, if the point has force, an unwholesome condition and a doubtful means of bringing the power of public opinion to bear on industrial strife.

Commenting upon certain bills to establish a similar court in New York, Governor Nathan L. Miller, himself formerly a judge of the Court of Appeals, expressed the opinion, as reported, that "they go a great deal farther in the direction of establishing State control over labor and industry than the people of this State are prepared to accept. One of the fundamental objections to the bills, as the matter appears to me, is that they undertake to set up a judicial machinery to adjudicate on questions which I do not think are subjects of adjudication; for example, the question of wages. That is a matter of contract. It cannot properly be made the matter of judicial determination according 
to any settled or known principles of law. I doubt very much that the State can undertake, for example, to compel people to work for less wages than they are willing to work for. ... What the State can properly do, it seems to me, in the way of helping in the settlement of industrial disputes is along the line of endeavoring to secure fair dealing to prevent abuses; to, as far as it can, set up machinery for mediation and arbitration, and $I$ think that perhaps the greatest thing it can do is to secure exact information of the facts involved in these disputes, so that the public may know what the facts are."

A feature of the Kansas law which has drawn serious criticism from the side of capital is that it empowers the court, in settling a wage dispute, to decide also what is a "fair profit." To fix rates of wages and profits means, logically, the power to fix prices also. Business men have been quite as unwilling to submit the matter of prices and of "fair profit" to the opinion of a court as workingmen are to accept a court's judgment on wages. Mr. Hoover points out, in this connection, that: "Unsuccessful plants, instead of abandoning production to competitors, will claim wage reductions from the courts, and the general level of wages can thus be driven down and the State, at least morally, becomes a guarantor of profits in over-developed industry." 1 He makes the further comment that: "There are some things worse in the development of democracy than strikes and lockouts, and whether by legislative repression we do not set up economic and social

${ }^{1}$ Industrial Management, April 1921, p. 229. 

perils of worse character is by no means determined. Government control also hinders the real development of self-government in industry, and that is part of the growth of democracy itself. Courts and litigations are necessary to the preservation of life and property, but they are less effective as a stimulus to improved relations among men than is discussion and a system of voluntary settlement of differences." 


\section{XI \\ INDUSTRIAL DEMOCRACY}

THe widespread faith in democracy as the final answer to the labor problem is a sign of the times which cannot be mistaken. To some it is the spirit of democracy as a guiding rule of conduct which alone matters; to others, some particular plan of working relations is all-important. In still another view, the special plan has its importance but depends wholly for success upon the spirit and character of those entering upon it. Industrial democracy, in fact, means many things to many people.

\section{WHAT INDUSTRIAL DEMOCRACY MEANS}

To the bolshevist it means middle-class rule, and he condemns it. Dictatorship, whether of capital or of the proletariat, is of course the opposite of democracy.

To the socialist it means common ownership of everything used in production.

To the Industrial Worker of the World and to the guild socialist it means possession and management of plants and industries by the workingmen who operate them. It means this also to the believer in coöperative enterprises, except that the workmen in this case raise the money and buy the plant or store instead of taking it by force or taxation. 
To the trade unionist, industry is democratic when the conditions under which the wage-receiver puts his time and effort into the enterprise are agreed upon voluntarily between workingmen and employers, each organized and represented as they may choose.

To many students and writers on the subject, and to a large number of employers who are trying experiments, democracy in industry means giving workingmen a voice in the management, not through trade agreements, but through joint meetings with associations, or delegates of associations, formed of employees only. Sometimes a wage-earner chosen by the employees is invited to sit on the board of directors.

\section{COÖPERATIVE MOVEMENTS}

Voluntary coöperation is one of the oldest ventures in industrial democracy, and it refuses to die in spite of many failures. In most coöperative schemes the members of the association provide the capital, each having one vote in the management of the business. Some hire a manager, some elect managing committees from their own members.

Just after the Civil War a number of short-lived coöperative producing enterprises were started by workingmen, and later on many similar experiments were made by the Knights of Labor. In the '70's the Patrons of Husbandry and Sovereigns of Industry engaged in coöperative buying and selling, but with little attention to the conditions under which goods were produced. Trade unionists complained that "the only object of 
the Sovereigns is to buy cheap." All these experiments were handicapped by lack of capital, of technical knowledge, trained management and experience with markets and finance. They were obliged to meet bitter competition and in some cases railroad discrimination. When they attempted to build up markets by lowering prices, they found that the wages of their own fellow workmen, employed by competitors, would be cut.

In coöperatve manufacturing there has been little or no headway since these early failures, but there have been many successes in later years in coöperative buying and selling. In this country the idea has been taken up much more extensively by farmers than by workingmen, although some coöperative stores, bakeries and restaurants are operated by wage-earners. The coöperative bank of the Brotherhood of Locomotive Engineers carries the idea in a new direction, and workingmen in the building trades in some places have been studying the possibilities of coöperative contracting.

Distributive coöperation has back of it the experience of several great coöperative movements in Europe, particularly in Great Britain. The British societies, dating from the Rochdale pioneers of 1844, have now some four million members, with a sum total of annual sales exceeding one billion dollars. With the benefit of many years of business experience and the financial ability to command competent management, they are also producing goods to a value of upwards of one hundred million dollars in their own factories; however, on business principles resembling those of an ordinary corporation more than of the earlier coöperative schemes 
which proposed to abolish capitalism and the wages system.

For instance, employees of the coöperative societies have joined trade unions, raised wage questions and engaged in strikes in quite the same manner as workmen in private employments. The movement is in fact a "middle class" rather than distinctly a labor enterprise; the great majority of workingmen in the lower wage levels do not belong to it, and the well-to-do are not sufficiently interested in small economies to pledge their patronage to coöperative stores. The British coöperatives have gone into politics, are affliated with the Labor Party, and have for one of their proclaimed objects "the democratizing of state services-civil, commercial and diplomatic."

In the United States the history of workingmen's coöperative ventures has been marked by so many financial disasters and "fake" enterprises that organized labor in recent years has given it little attention. The American Federation of Labor has, however, for information purposes a bureau of coöperative societies, and publishes detailed instructions to workingmen on how to start coöperative stores, including the "model constitution" under which one such enterprise has been successfully carried on in Illinois for a number of years.

\section{EMPLOYEE REPRESENTATION}

To most employers who have become interested in the idea of industrial democracy the idea does not go 
beyond some very definite plan for their own plantsthe "company union," works council, shop committee or industrial legislature. In some cases it is a sincere attempt to meet the rising demand of labor in a spirit of democratic common counsel; in others, the motive quite obviously is to forestall or dislodge labor organizations. Where employees are required to join a shop association of this nature, or to present their grievances and requests through this means and no other, the objection is raised that virtually a "closed shop" is established, by the company in this case instead of by agreement with a union, and usually so devised that the workers can in no way out-vote the management in the final decision of a vital matter. Many of these experiments are no doubt fairly open to these criticisms; at any rate, few of them as yet have won the confidence of the labor movement.

Some two hundred plans of employee representation are described in a report on "works councils" issued by. the National Industrial Conference Board, the largest association of employing interests in the United States. Many other accounts of interesting experiments are in print, but the scheme which has attracted most attention is that worked out in the Middle West by Mr. John Leitch, described in his book "Man to Man."

In theory this plan is modeled upon that of the United States government. A house of representatives is elected by the main body of wage-earners. The senate consists of department heads and sub-foremen. At the head is the company president with a cabinet of executive officers. Any matter of employment rela- 
tions may come up in either the house or senate, and upon passing both goes to the cabinet, which holds the final veto power.

It is reported that the frequent conferences these plans provide for have in many cases built up a friendlier relation and disposed of grievances which might otherwise have grown into serious disputes. In some instances wage increases which the employees voted to themselves have been approved by the management. It is pointed out, however, that should such a request be refused the employees have no recourse but to drop the matter or quit the service, precisely as in the case of a company which has no such system in operation, when the same point is reached. If the parallel were complete, between this type of industrial democracy and the Federal government, the president and senate would themselves be elected by the main body of employees, in which case there would be of course less point to the labor view that the plan is democratic more largely in name than in fact and has not the balance of power essential to actual democracy.

Some of the other types of employee representation are less elaborate and rely mainly on the good effect of regular meetings with shop committees to discuss matters of common interest. This plan in one form or another has been familiar practice in some industries for many years, and in relations with organized workmen as well as unorganized. Almost always it works a real and substantial change for the better in the relations of managements and men. 
Generally, it may be said, the employee representation plans have worked best in factories away from the large centers and so "out from between" the main lines of industrial controversy. They would be much more difficult to operate, of course, in great industries scattered over immense territory, such as coal mining and railroad transportation, in which long established trade unions maintain regular agreements with corporations. It seems highly doubtful that the idea will supplant independent labor organization, at least for a long time to come. In fact, believers in industrial democracy who do not limit it in their thinking to any particular scheme have no expectation that it will do so. They look, rather, for a uniting and development of the features in each which best serve the human needs of industry.

And there are signs here and there of just such a possible interworking of some of these employee representation plans with established labor bodies. It is strongly recommended in the able and far-seeing report very recently issued by the New Jersey Chamber of Commerce. The second National Conference on Industrial Relations, of 1919, recognizing the value both of trade unionism and of the shop council idea, noted that: "In many plants the trade union and the shop committee are functioning harmoniously. In some establishments the men are unionized, and the shop committees are composed of union men. In others, some men belong to the trade union, while all belong to the shop organization." The members of the conference, 
including a number of employers, agreed that workingmen must have absolute freedom in the selection of their representatives and "must feel absolutely convinced that the management will not discriminate against them in any way because of any activities in connection with shop committees." In the judgment of the conference, the idea "offers no royal road to industrial peace" but "only a means whereby sincerity of purpose, frank dealing, and the establishment of common interests may bring mutual advantage."

\section{LABOR AND INDUSTRIAI ENGINEERS}

A new approach to more democratic relations in industry, without the creation of new machinery, has appeared quite recently in conferences between industrial engineers and labor representatives. Certain eminent engineers took especial note of the resolutions adopted in 1919 by the American Federation of Labor, in which it was recognized that "there is a limit beyond which the average standard of living of the whole population cannot progress by the usual methods of adjustment, which limit can only be raised by research and the utilization of the results of research in industry." By the same resolutions the Federal government was urged to foster "a broad program of scientific and technical research."

Thereafter, in the course of an investigation of general industrial conditions, the Federation executives were in frequent conference with a number of mechanical and industrial engineers interested in the labor 
view of practical management problems. Mr. Gompers addressed the American Society of Mechanical Engineers on this subject in November, 1920, and the executive council of the Federation soon afterwards discussed at length with Mr. Herbert Hoover and Mr. Robert B. Wolfe the principles upon which a democratic relationship with the human element in industry might be combined with efficient production.

At the first convention of the newly formed Federation of Engineering Societies, with a membership of between one and two hundred thousand engineers, Mr. Hoover outlined a broad "area of common interest between employer and employee" based upon "the great human conception that this is a community working for the benefit of its human members, not for the benefit of its machines or to aggrandize individuals." The American Federationist has since published several articles and addresses of representative engineers on the results of certain progressive labor policies technically worked out and applied in test cases.

The modern engineer, standing in a sense between employers and workingmen, has the immense advantage of expert knowledge of practical problems. He has discovered, much in advance of many owner-employers, that industrial success to-day depends only in part on tools, more on the relations established with the men who use them. In other words, as this type of engineer sees it, more democracy in industry is not merely a theory but a necessity. Mr. W. B. Dickson, a former partner of Andrew Carnegie, addressing the American Society of Mechanical Engineers in 1920, insisted that: 
"American industry has come to the parting of the ways; on the right is the road that leads direct to industrial democracy. ... The choice lies between democracy on the one hand and serfdom or chaos on the other." And Mr. Gompers, from the labor angle, interprets "the idea of consultation, of treating workers as human units," which he finds now in the minds of most engineers, as "the heart and core of democracy."

\section{RESTORING THE HUMAN RELATION}

The old-time system of cottage industry was democratic because of this close human relationship, but we are accustomed to say that the personal relation has been lost, that "corporations have no souls." If such is the case, it is not at any rate because industry is any the less alive with humanity from top to bottom, with a thousand men than with ten. At every point men are in daily and hourly contact with men, up through every gradation of day laborer, artisan and foreman to general manager and president. The personal relation did not get lost in the modern corporation; it was always there, but it became autocratic. When it becomes again democratic it will do for large industry essentially what it did for small.

In many successful enterprises to-day it is understood and required as a first principle that every man who directs the labor of another man is responsible for that man's good will no less than for his output. Indeed, it is a sign of the hold this idea has gained already in industry that "employment management" 
has become a distinct profession. More than five hundred industrial companies which are attempting to rebuild a personal and democratic relation in industry through these men of "trained mind and humane spirit" were represented at the Rochester conference of employment managers in 1918.

The drift to democracy is worldwide and cannot be turned back; it springs from a common human instinct. The many experiments in its name, even those which wear the livery of a good cause for a motive, signify at least a growing sense of the fact that this is to be the governing principle of future relations in industry as in government and in community life. It will get itself into action in many different ways. The form it takes in industry may be unlike that in politics, but it will establish the workingman as first of all a human being with rights to a voice in whatever affects his occupation, his life and well-being.

We shall have less and less a problem of "capital and labor," more and more one of men working together, those who direct and those who execute, upon a basis to which both have given assent. It is a wholesome thing that many experiments are on trial for giving this idea freer play: they will all come sooner or later to a very simple test. They will be democratic in fact, and so meet the demand of the time, in the degree that the spirit of genuine democracy runs through them. 


\section{XII \\ WHAT SHALL WE DO ABOUT IT?}

Is there, then, no one simple panacea, no short and quick answer to this labor question?

Is it worth the effort to know what any problem of modern democracy actually is and what it means if we still are not sure of the exact thing to do in every instance?

It might not be, if some infallible authority could make the decisions for us. But the self-government we insist upon actually means governing ourselves-that is the heavy price we pay for it. It means deciding how to get on with each other, for we cannot get rid of any part of this immense neighborhood of humanity if we would. For the family, the nation, and now for the world, the problem of living together is answered only by learning how to live together. It is that, or go back to the law of the jungle-every man for himself. And a part of the learning how is to take the other man's own word for just what it is he wants out of the common life, and why; if we expect him to do the same by us.

OPEN MIND AND FAIR JUDḠMENT

But we do not get his case if we will listen only to those who vehemently attack it and defend our own. 
The matters at issue to-day between workingman, employer, farmer, are too serious for this child's play. One of the chief of stumbling blocks to a spirit of coöperation strong enough to override industrial differences, as the "will to agree" was able to override national differences in the Arms Limitation Conference, is the fact that so many men with whom the great decisions rest will hear only the speakers, read only the books, that champion the ideas they wish to believe. An employers' association imagines it is studying the labor question when its own attorney takes the platform to denounce the doings of a particular trade union. A labor meeting imagines it is getting the whole story of modern industry and finance in a bitter recital of wrongs at the hands of capital.

\section{IS THERE A "FINAL ANSWER"?}

But suppose that an open mind and fair judgment still give us no clean-cut, final "solution." What of it? We have not discarded the Golden Rule because, after nineteen centuries, men still disagree on how to apply it. In what direction, in what issue of daily life does the man who understands as a man and has put away childish things expect in a moment a final solution? To every solved problem a new one succeeds-it is the penalty, the very law and necessity of progress. The important point is not that the next step shall take us all the way but that it shall take us nearer. We expect too much of the immediate act, have too little faith in the final event. 
We may grant, for instance, that to know both sides of the closed-shop question, or all the reasons why workingmen strike, probably will not settle it for the farmer or any other citizen just what he should think or do about any particular struggle of labor. But it may make clear a much more important thing-that the policies of the moment, however mistaken we may feel them to be, are not the principal deciding fact about any great human movement. It may save us the futile and costly attempt to fight down legitimate efforts for a higher standard of life-legitimate for workingman, farmer, for anybody-efforts which in the total go to make up the progress in welfare of the whole community.

\section{PROGRESS BY GROUPS}

For the fact becomes clearer, with the study of every social movement, that the whole communtiy does not at any one time go forward abreast. By the efforts of a group here, another there, mainly in its own behalf, it is true, the conditions of life and of work for all come at length to a higher level. It is just here that our very faith in community welfare as the ideal may lead us into disheartening errors, as many broad generalities do when we do not think them through. Were we to wait until an entire population could better its lot equally and together, before we would permit any portion of it to do so, we should have perpetual deadlock. Not a step in the progress of civilization could have been taken by such a rule. 
It is perfectly true that if the aims of some portion of the community can be realized only to the permanent cost or harm of some other, they are not legitimate. Even if won, they will not endure. No group. can lift itself by pulling another down. Is there no other way?

Suppose we say it is for the good of the community that all men have a voice in the making of the conditions under which they work and live; that every man's honest labor ought to afford him the means and the leisure not merely to exist but to share reasonably in the civilization of to-day, to give his children a fair start, to make due provision for misfortune and old age. If these are legitimate aims for all men, can we say they are not legitimate if workingmen, if farmers, each attempt to achieve such of them as they can through the means nearest at hand-the industries in which they are engaged?

It would not be a legitimate thing to do if it were true that a higher level of welfare for some is built up only at the expense of all others. If such were indeed the fact, the rise of modern agriculture would have laid heavier and heavier burdens upon the rest of humanity everywhere. Instead, it has lifted burdens the world over. In the same way, the tremendous rise in wages of industrial workers in the last hundred years would have reduced every modern nation long since to bankruptcy. Instead, the era of highest wage levels ever reached is also the era of largest earnings of capital. 


\section{EXPLOITING NATURE, NOT EACH OTHER}

Clearly, if the gains of either had merely been taken from the other, we should have made no net advance. Our immensely increased output is the product of natural forces harnessed by machinery in infinite variety; of management efficiency, trained skill and waste-saving organization. Competition on the one hand, labor on the other pressing constantly for a larger share, have spurred invention to make up these heavy drafts by new economies. Each has yielded new margins of profit in the place of that which had been absorbed, and out of this surplus the capital has been supplied for new plant and equipment essential to the further expansion of industry.

Of the several possible sources of larger earnings for labor, says Rowntree, an increased productivity of industry, "whether due to better organization and machinery, greater efficiency on the part of workers or management, or any other factor," is undoubtedly the most important. "We cannot limit its possibilities. The war has shown that, when the need arose, huge improvements could be made with incredible rapidity in process after process, and industry could be so organized that, without adding to the strain on the individual worker, the output was enormously increased." 1

\section{CONSUMING POWER THE BASIS OF PROGRESS}

But all this growth in the power to produce has de1 The Human Needs of Labor, p. 137. 
pended and does depend upon an equal growth in the power to consume-not merely the power to want things but to pay for them. And it is not the purchasing power of a wealthy few that keeps the mill of a thousand looms in operation or freight by the millions of tons in motion. Modern industry rests back upon what the great mass of the people can buy-almost wholly upon the welfare of the farmer and the wage and salary earner.

The wage roll of the country, figured now in the billions instead of millions, makes up so large a part of the market demand that to cut it in half, for instance, would be to paralyze the greater part of the nation's industries at a stroke. Conservative reviewers of business conditions have commented that the recent wage reductions, however inevitable in the general deflation of the "war boom," greatly lessened the community's buying power and by so much delayed the return of business activity. The National City Bank, of New York, noted in a recent bulletin that: "Labor leaders are laying emphasis upon the importance of keeping up wages as a means of maintaining consumption and the argument is based in part at least on sound principles."

It is because of this broad interdependence of all industry to-day that a rising standard of living for either wage-earner or farmer is not in the long run at the expense of the rest of the community. Actually it is one of the conditions upon which the advance in general welfare depends. To acknowledge this is not, of course, to justify a permanent level of war prices nor 
of wage advances at a rate beyond the capacity of invention and engineering science to make up in larger production. Probably, indeed, it is the sudden jumps in wages such as the war inflation gave us that have had much to do with the feeling that "the public must pay" for whatever progress labor is able to make. In emergency circumstances that is in part true. In the long-range movement of economic causes and effects it is nearly the opposite of true.

\section{THE DEEPER PENALTIES OF WAR}

Farmer and wage-earner alike have been charged with responsibility for burdens which the war laid upon all humanity. Now, in calmer days, sensible men acknowledge that the high prices of food products for the time being were no more due to manipulations by farmers than the great rise in wages following the rise in living costs, or the growing shortage of labor as millions of workingmen fell in battle, were due to the malign power of trade unions.

Even in the instances so commonly cited at the time, of arbitrary wage demands, deliberate slacking and reckless extravagance, there is a larger willingness to-day to acknowledge that no very excellent example was set to labor by the war profiteers and spenders in evidence somewhere in every community - a manufacturer or contractor here, a middleman or retailer there. We are no longer surprised that men and women who had never seen the means within grasp for anything more than to-day's necessities exclaimed: "They are 
all getting theirs-we will get ours, while we have the chance!"

It is a hateful chapter, but a closing one: a chapter that not so much fastens guilt upon one group and acquits others as it reveals some of the deeper penalties of war in its after effects upon the human spirit.

Whether industrial wages, on the average, since the late reductions, are higher to-day in proportion to cost of living than they would have been with the normal increase a ten-year period of prosperity ordinarily brings, is a debated question which cannot as yet be answered. In some occupations probably they are, in others not. Further readjustments will take place, but the vital question for wage-earner and for farmer is not the give and take of readjustments of the moment, but the general attitude. As a citizen of the community in which everything he has is staked, what is the constructive, the upbuilding thing for him to do?

\section{THE INDUSTRIAI WORLD KNIT TOGETHER}

Most of his fellow citizens hold to the idea that the industrial world is somehow tied together in a relation of mutual benefit, in spite of all its human elements of friction. The labor movement does not deny itits entire working program in fact is based upon it. "The spirit of trade unionism," says the foremost historian of American labor movements, "instead of being that of class struggle, is the spirit of partnership. The trade-union movement looks upon itself, not as the irreconcilable opponent of capitalism, but as a member 
of the family." 1 Capital welcomes the idea of underlying unity of interest, particularly when its own function in the scheme of things is under attack. The farmer knows that every man who does not raise food products is his customer.

We have enough of common interest, enough agreement on fundamentals, to give us a standard of facts, a code of principles for common reference in working out the necessary readjustments as they arise. And we ought to know by this time from a world of experience that any readjustment, any code, only "works" as we have ourselves the disposition and will to make it work. Simply to announce it and then "stand for law and order," as every good citizen must do anyway, is to touch barely the fringe of the human elements in the real industrial problem.

Industry and agriculture, particularly, are knit together. Each in great part is a labor question. Will it help the problem of either to insist that the other take a step down in the scale of civilized living, in order that his products may be cheaper? We have already seen that the economic cheapening of the means of welfare is by quite other means than cheap labor, whether of factory worker or farmer. Will it help the problem of the rest of the community-business man, professional man, writer, scientist-to demand that one group first, then another, be content with lower standards of life in order that-perhaps-costs may be lower? Or, might we find when such a process is com-

${ }^{1}$ Industrial Goodwill (Commons), p. 194. 
plete that none have advanced but all have gone backward?

\section{COÖPERATION AND DEMOCRACY}

To face forward is to find ways of coöperating rather than of pulling down. It is to turn to every legitimate means of raising the productivity, saving the wastes, utilizing the larger opportunities, in one's own quarter of the nation's industry, in the factory, in commerce or on the land. This may mean many things-more technical research, more machinery, new sources of power, better organization, better training for efficiency, coöperative buying and marketing, new applications of science and skill as yet unforeseen. Above all, for the ethical and social values which alone give industrial progress its justified meaning, we shall find ways to build into our working relations that democracy and humanity which lift the burden of ill will and disputes and idleness and unite men in larger creative effort.

"Be loyal to yourselves, be loyal to your own people," said James H. Thomas to American trade unionists at Denver, in 1921: "Recognize that not as a class but as citizens of a great community you must discharge your obligations."

With that saving clause in mind neither workingman nor farmer will drive his own bargain to the point that industry declines because he is taking more from the community than he gives. Neither will he think it possible, in the long run, to get more for his own labor by requiring other men to take less for theirs. He will 
face the way Lincoln faced in his address to workingmen in 1864, no less to the point for any man or class :

"Let not him who is houseless pull down the house of another, but let him work diligently and build one for himself, thus by example assuring that his own shall be safe from violence when built." 


\section{INDEX}

Agitators, labor, 1

Agriculture, National Conference on, 49

Allen, Henry J., 163

Amalgamated Clothing Workers, 53

American Farm Bureau Federation, on labor, 8

American Federation of Labor: attacks upon, 43; attitude towards employers, 39, 185 ; and coöperative movement, 170 ; democracy of, 111; expenses of, $38,42,50$; and foreign labor movements, 89, 91,111 ; history and achievements, 39; ideals and motives, 107, 111; membership, 52 ; origin, 38 ; plan of organization, 50, 109; political policies, 45, 104; publicity and periodicals, 39,51 ; reconstruction program, 47, 103; reformist policy, 107, 111 ; against revolution, 40, $48,65,112$; in World War, 46,109

Anarchism: theory and agitation, 54, 55; Chicago riots, 43 ; in Italy and Spain, 84, 87

Appleton, W. A., 70

Apprentices, in English mills, 23 ; regulation of, $27,39,128$ Arbitration, voluntary and compulsory, 44, 72, 139, 155, $157,166,174$

Arkwright's spinning frame, 21 Arms Limitation Conference, labor coöperation with, 49 Australia, compulsory arbitration in, 157
Ball, John, 16

Bakunin, Michael, 84, 89

Bauer, Gustav, 82

Bebel, Ferdinand, 79

Belgium, labor and socialist movements, 87

Benefit features of trade unions, 38

Berger, Victor, 61

Bernstein, Edward, 88

Berne, labor and socialist conference, 1919, 89

Bissolati, Leonida, 86

Blacklisting, 134

Blincoe, Robert, 23

Boston Chamber of Commerce, on labor relations, 126

Boycotting, 134

Briand, Aristide, 78

British Labor Party. (See Great Britain).

Brook Farm Community, 59

Building trades disputes, New York, 130, 135, 139

Burns, John, 69

Cartwright's power loom, 21

Capital: abuses of, 30, 131, 184; concentration of, 41 ; control of, $73,77,106$; function of, 182, 186; human aspects of, 176; profits of, 181

Canadian strike investigation law, 157

Carnegie, Andrew, 147

Channing, William Ellery, 34, 59

Chartist movement, 29

Cheap-labor doctrine, 24, 32, 183,186

Child labor: A. F. of L. and, 
39, 102, 104; in America, early conditions, 34 ; in England, 22; legislation on, $29,37,154$

Christensen, Parley P., 64

Class hatred, and early mill slavery, 25,30

Class struggle, 84, 91, 99, 185, 187

Clayton law, labor clause, 45, 122

Closed shop. (See Union shop). Clynes, J. R., 70

Coercion of labor, 115, 162, 164

Collective bargaining, 8, 13, $39,45,140$

Collective ownership. (See Socialist movement).

Combinations of labor. (See Labor movement-Legal regulation-Unions ).

Commons, John R., 194

Commodity, labor not a, 45, 103

Communist movements, 25, 59, $63,75,77,79,84,87,90$

Community point of view, 5, $178,180,185$

Conboy, Sara A., 51

Conspiracies, labor, 18, 27, 29, 39

Consumers' League "white list," 135

Consumption. (See Market demand).

Contract labor, 36, 39

Coöperation, industrial, 36, 40, 59,168

Coöperative marketing, 13, 104, $143,168,187$

Cost of living, 72, 98, 145

Cottars, first wage-earners, 16

Courts, scope and duties of, $115,117,122,166$

Craftsmen, early, 19

Crompton's spinning-frame, 21

Dana, Charles A., 59

Danbury hatters' case, 143
Debs, Eugene V., 61, 62

De Leon, Daniel, 61

Dickson, William B., 175

Dictatorship of proletariat, 63, $66,89,117,167$

Disarmament, 49, 77, 84

Diseases, industrial, 23

Distribution of labor, 152

Duncan, James, 47, 51

Education, labor and, 31, 34, $39,41,72,80,84,102,106$, 187

Efficiency of labor 131, 182, 187

Eisner, Kurt, 82

Elizabethan -abor laws, 17

Ely, Richard T., 32

Employee representation. (See Industrial democracy).

Employers : attitude on wages, 99 ; concerted action against labor, 36, 126; under "domestic system," 20, 176; in early factory system, 21, 24; labor view of, 39,185 ; obligation of, in strikes, 119; plans for employee representation, 170 ; welfare work of, 149

Employment agencies, 106, 152 Employment management, 176

Engels, Freidrich, 59, 79

Engineers, industrial; and labor, 174

Fabian Society, 68, 70

Factory Acts, English, 29

Factory system; rise of, 20; effects on labor, 22; early conditions in America, 32

Fair dealing in industry, 131, $146,151,165,172,177,187$

Farmers: attitude towards labor, $7,180,185$; common interests with labor, 5, 142, $152,178,181,183,185,186$; "farmer's trusts," 13, 184; injunctions against, 122; political coöperation with la- 
bor, 36, 37, 63, 73; public opinion and, 111,116 ; wageearner's life contrasted, 10

Farmer-Labor Party, 63

Farm program of British Labor Party, 72

Fascista movement in Italy, 66

Feudal system, 16, 161

Foremen: in early factory system, 21 ; in modern industry, 176

Fourierism, 59

France: labor and socialist movements, 75, 77; labor's reconstruction program, 77

Frayne, Hugh, 51

Free schools, labor's efforts for, 34

Free speech, 104

Frey, John P., 51

Furuseth, Andrew, 51

Geneva, labor and socialist conference, 1920,89

Germany, labor and socialist movements, 66,78 ; recent aims of workers, 80

Gibbins, H. de B., 20, 22, 29

Glasgow strike of 1812, 28

Goldman, Emma, 54

Gompers, Samuel, 38, 39, 46, $47,48,49,50,51,107,108$, $112,129,176$

Government ownership, 69, 72, 104

Graft, labor, 132

Grand National Consolidated Trade Union, 1833, 28

Grange, National: on labor, 8

Great Britain: coöperative movement, 169 ; Labor Party, $64,68,70,74,75,89,95$, 170 ; labor's reconstruction program, 71 ; rejection of Russian program, 75; trade unions in, 67, 150, 162

Great Plague, 1348, effect on wages, 16

Greeley, Horace, 59
Greenback agitation, 36

Gregory, Stephen S., 144

Guilds, early workingmen's, 19,128

Guild socialism, 54, 68, 167

Hanna, Marcus A., 44

Hargreaves' spinning jenny, 21

Haywood, William D., 55

Henderson, Arthur, 69, 74

Hillquit, Morris, 60, 91

Holland, labor movement in, 87,90

Homestead steel strike, 43

Hoover, Herbert, 160, 165, 175

Hours of labor: American labor demand, 102; British, 72; French, 77; Italian, 84; early experience in America, 32, 34; in England, 22, 24; Peace Treaty clause, 94; regulation of, $29,36,37,40$, 154; Washington Conference proposal, 95

Housing, workingmen's, 10, 12, 72,106

Hughes, Prime Minister, 157

Humanity in Industry. (See Fair dealing-Personal relation).

Immigration: A. F. of L. attitude, 106; effect of contract labor law, 36; influence of trade unions, 41 ; rise of, 32

Incorporation of labor unions, 39,143

Individual contract, 134

Individual liberty in labor relations, $27,35,100,112$

Individual and public, rights of, 115,125

Industrial democracy, 20, 61, $77,81,85,100,103,110$, $166,167,176,187$

Industrial Courts. (See Kansas Court).

Industrial Relations, Presi- 
dent's Conference, 1919, 14I, 158, 173

Industrial revolution, 18th Century, 20

Initiative and referendum, 102 Injunctions, labor, 40, 102, 120

Insurance, workingmen's, 72, $84,102,149$

"Intellectuals," in socialist movement, $60,62,110$

Intercollegiate Socialist Society, 61

International Federation of Trade Unions, 87, 92

International, First, Second and Third, $55,63,65,75,77$, $79,83,88,90$

International labor office, 78, 94,96

International labor relations, $36,47,59,66,69,78,80$, $83,88,92$

Italy: Fascista movement, 66, 85 ; labor and socialist movements, 82; labor reconstruction program, 84

Inventions, the great industrial, 20

Industrial Workers of the World, 42, 54, 68, 167

Johnston, William H., 51 Jouhaux, Léon, 78

Jurisdiction disputes, 127

Kansas Industrial Court, 160

Kautsky, Karl, 82

Knights of Labor, 37, 58, 168

Labor Board, Railroad, 160

Labor costs, effect on farmer, 3

Labor legislation, 27, 29, 34, $37,45,84,92,95,104,154$

Labor movement. (See A. F. of $L$., and under nation headings).

Labor Statistics, Bureaus of, 37,39

L'Avanti, 86
Law and order, 116. (See Violence).

Lazzari, Constantino, 86

Land, socialization of, 72,84

Lassalle, Ferdinand, 79

League of Nations, 77. (See International Labor OfficePeace Treaty).

Legal regulation of wages and unions, 17, 18, 27, 28, 75 . (See Injunctions-Investigation-Kansas Court).

Legien, Karl, 82

Liebknecht, Karl, 82

Liebknecht, Wilhelm, 79

Limitation of Output, 129

Lincoln, Abraham, 188

Lloyd George, Premier, 47

Longuet, Jean, 78

Los Angeles Times, explosion, 43

Low, Seth, 44

MacDonald, J. Ramsay, 70

Machinery, opposition to, 128. (See Capital).

Malatesta, Enrico, 86

Mann, Horace, 34

Market demand and high wages, 103, 183

Marx, Karl, 59, 78, 79, 88

McNamara brothers, crime of, 43

McNeill, George E., 107

Mediation. (See Arbitration). Militarism, labor position on, 106

Miller, Fred J., 130

Miller, Nathan L., 164

Millerand, President

Minimum wage. (See Wages).

Mitchell, John, 107

"Molly Maguires," 37

Morrison, Frank, 51

Mutual obligation of industrial peace, 119, 137

Napier, Sir Charles, 134

Napoleon III, 76 
National Board of Farm Organizations, on labor, 7

National Civic Federation, 44, 156

National Industrial Conference Board, 171

National Labor Union, 1866, 35

National Party, 1878, 37

New Jersey Chamber of Commerce: on open shop, 126; on employee representation, 173

New Zealand, compulsory arbitration in, 157, 163

Norwegian Labor Party, 90

O'Connor, T. V., 51

"One Big Union," 56. (See I.W.W.).

Open shop, labor view of, 124, 126,134

Organization, right of, 8, 102, 141 ; by early mill workers, 25 ; by trades, 35,57

Oudegeest, Jan, 87

Owen, Robert, 29

Owen, Robert Dale, 59

"Panaceas" for labor problem, 138, 179

Paris Commune, 76

Parliament, British, labor representation in, 68,69

Paternalism in labor relations, 151, 155

Patrons of Husbandry, 168

Pauperism, 18

Peace Treaty, Labor relation to, $47,77,78,93$

Peasants' Revolt, 1381, 16, 161

Pensions, old age, 149

Personal relation in industry, $20,100,176$

Picketing, 134

Piece-rates, fixing of, 130

Political efforts of labor, 27, $31,35,37,39,45,64,74$, 104

Powderley, T. V., 58
Prison labor, 39

Profiteers, 135, 184

Profit sharing, 146

Profits of capital, 181

Progress, method of, 138, 179, 187

Prosperity, and wages, 183

Public's interest in labor disputes, 113, 116, 118, 125, 161

Public opinion on labor, 119, 132

Purchasing power. (See Market demand).

Quarter sessions, Courts of: wage-fixing powers, 18

Railroad Brotherhoods, 40, 52, 169

Reconstruction programs. (See $A$. $F$. of $L$., and under nation headings).

Representation, employee. (See Industrial democracy).

Revolutionary propaganda: in America, 53, 56, 63, 65; distinct from trade unionism, 54 ; effects on early unions, $25,31,34,36$, efforts to control, 55, 62; in Europe, 75, $81,83,84,89,90,93$; position of American trade unions, 40

Rochdale pioneers. (See Cooperation, industrial).

Rogers, Thorold, 18

Roosevelt, Theodore, 122

Root Commission to Russia, 47

Rowntree, Seebohm, 182

Russell, Charles Edward, 62

Russia. (See Revolutionary propaganda-Dictatorship).

Safety and sanitation, 102

Secret labor organizations, 37

Serfage, end of, 17

Serrati, Menotti, 86

Shaftesbury, Lord, 28

Shop rules, arbitary, 127, 131 
Smillie, Robert, 70

Smith, Adam, 28

Snowden, Philip, 70

Socialist movement: in America, 36, 59, 61; in England, 68, 71,73 ; in France, 75, 78; international, 89; in Italy, 83 ; rise of, 25 ; theory of, $59,60,167$; trade unions and, 40, 60; in World War, 46,62

Solano, E. John, 96

Soldiers and sailors, labor demand in behalf, 106

"Solidarity" of labor, 111

Sovereigns of Industry, 168

Soviet system. (See Revolutionary propaganda-Dictatorship).

Spain, labor and revolutionary movements, 87

Spargo, John, 62

Spies in unions, 136, 144

Standard of living, 97, 138, 180,183

Statutes of laborers, 1350, 17

Stephens, Uriah Smith, 58

Steward, Ira, 107

Stockholm Conference, 69, 89

Stokes, J. G. Phelps, 62

Stone, Warren S., 40

Strasser, Adolph, 38

Strikes: extent and results of, 123; English coal miners, 1920,74 ; first on record, 15 , 16, 28; French railroads, 1920, 76; Gould railroads, 1885 , 59; Lawrence textile mills, 1912, 55; "One big union" strike program, 56; profit sharing and, 148 ; railroad strikes of 1877,37 ; public concern in, 116, 117, 161 . (See Injunctions - Arbitration-Investigation-Kansas Court-Diolence).

Suffrage, workingmen's, 29, 72 Sullivan, James W., 51

Sweden, labor and socialist movements, 90
Sylvis, William H., 36

Syndicalism, 54, 68, 83

Taff Vale decision, 162

Tariff, protective; labor demand, 39

Taxation: of income, 73, 106; of inheritances, 84, 106; of land values, 73, 105, 106

Thomas, Albert, 78, 96

Thomas, James H., 70, 146, 187

Trade agreements, 45, 139, $141,145,168$

Trades Disputes Act, England, 122,162

"Triple Alliance," in England, $66,74,118$

Turati, Filippo, 86

Tyler, Wat: rebellion of, 16

Understanding, need of mutual, $5,9,136,165,174,177,179$, 187

Unemployment: A. F. of $\mathrm{L}$. position on, 102; efforts to relieve, 106, 152, 153; insurance against, 149; National Corference on, 1921, 49,153

Unions, labor: abuses of, 127, $136,180,184$; benefit features of, $38,149,152$; cooperation with farmers, 36, $37,63,73,152$; earliest forms, 16,26 ; and enforcement of labor legislation, 95; first in America, 31; and immigration, 41; national and trade lines, 35; "pure and simple," 35

Union label, 135

Union shop question, 124, 139, $142,171,173$

Unorganized workingmen, 101

Unskilled labur and trade unions, 41

Villeinage, end of, 17 
Violation of labor agreements, 145

Violence: A. F. of L. position on, 44, 119; early English factory riots, 27 ; efforts to control, 120; mine riots of '70's, 37

Viviani, Rene, 78

Wages: Amelican, before Civil War, 32 ; American labor position on, 40, 102, 104; British, 71; changing standards of, 97, 98, 145, 185; combinations affecting, 28; Italian position on, 84; "living wage," 104, 150; "minimum wage," 84, 98, 155 ; profit sharing and, 147; regulation of, $17,18,27,28$, $155,162,165$

Walking delegates, 132

Walling, William English, 62, 111

War: American labor in the, 46; European labor move- ments in, 66, 69; socialist position, 46, 62

Washington, International labor conference, 1919, 94

Webb, Sidney \& Beatrice, 69, $71,110,127,161$

Welfare work, 150

Whittier, J. G., 59

Wilson, Havelock, 70

Wilson, William B., 51, 150

Wilson, Woodrow, 47, 158

Wolfe, Robert B., 175

Woll, Matthew, 51

Women: in early American mills, 32, 34; in early English mills, 23; equal pay for, 102, 104; Labor League, England, 68. (See Labor legislation).

Workers' Party, 64

Workmen's compensation, 72 , 102,106

Wright, Carroll D., 41

Zimmerwald Conference, 1915, 84,89 







HD Robbins, Hayes

4901 The labor movement and the R6 farmer

\section{PLEASE DO NOT REMOVE \\ CARDS OR SLIPS FROM THIS POCKET}

UNIVERSITY OF TORONTO LIBRARY 

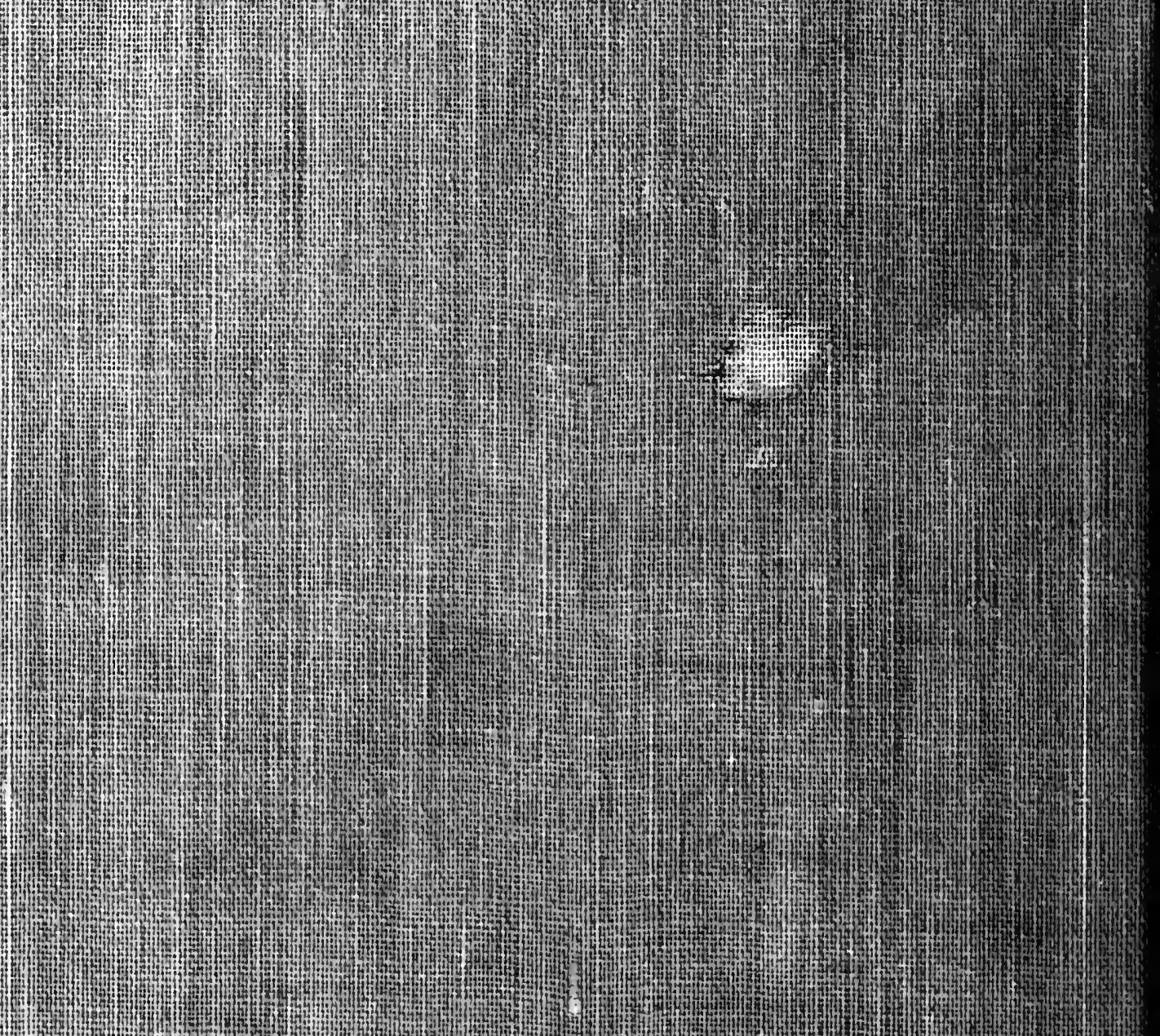

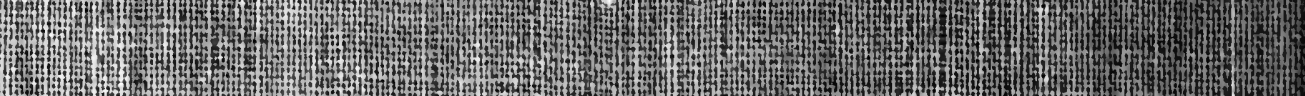

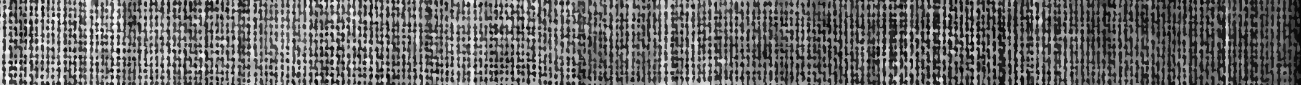

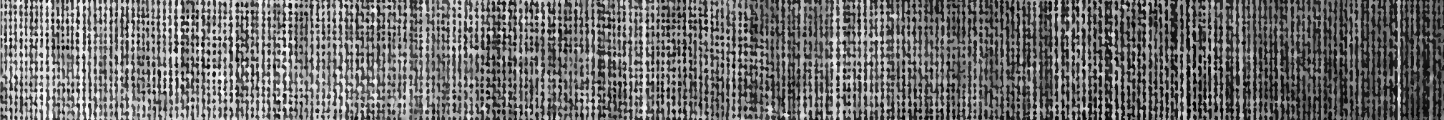
-

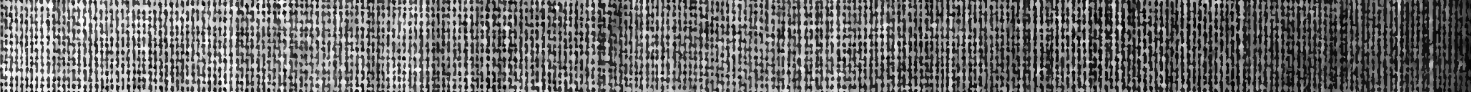

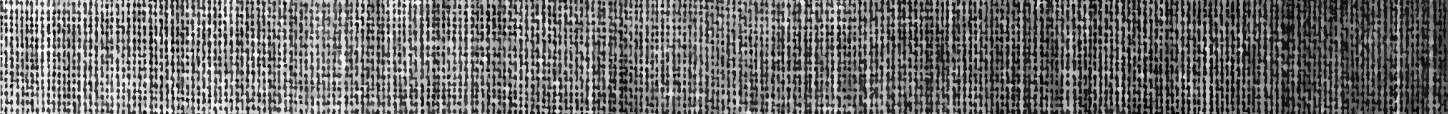

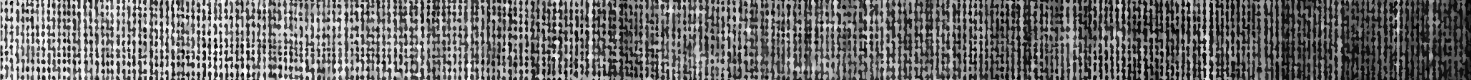

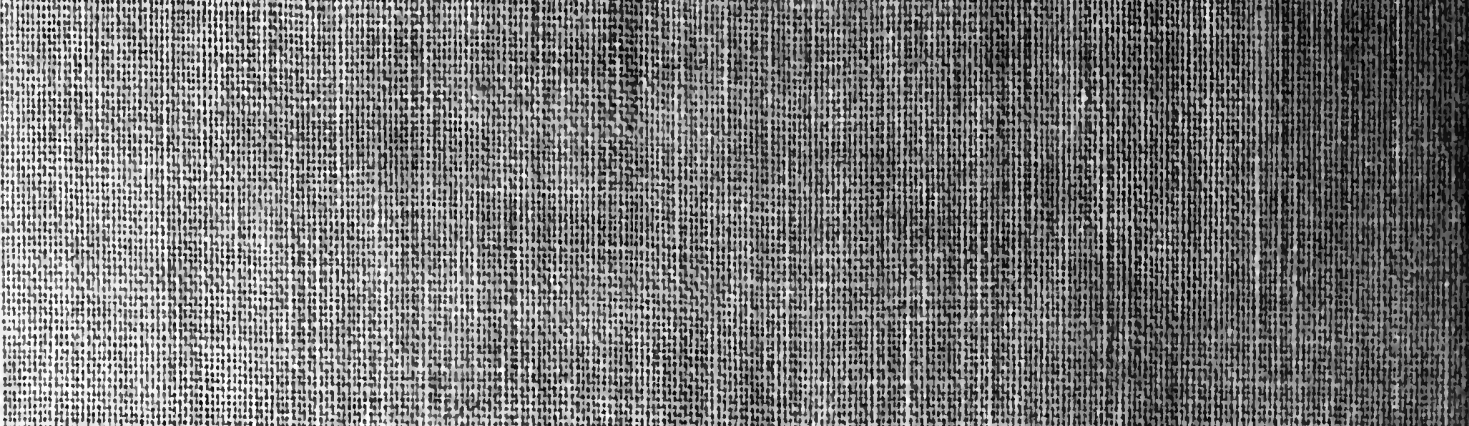

